\title{
Credit in the economy: small business default correlation and firms co-movements
}

Citation for published version (APA):

Pisa, M. (2015). Credit in the economy: small business default correlation and firms co-movements.

[Doctoral Thesis, Maastricht University]. Maastricht University. https://doi.org/10.26481/dis.20150513mp

Document status and date:

Published: 01/01/2015

DOI:

10.26481/dis.20150513mp

Document Version:

Publisher's PDF, also known as Version of record

\section{Please check the document version of this publication:}

- A submitted manuscript is the version of the article upon submission and before peer-review. There can be important differences between the submitted version and the official published version of record.

People interested in the research are advised to contact the author for the final version of the publication, or visit the DOI to the publisher's website.

- The final author version and the galley proof are versions of the publication after peer review.

- The final published version features the final layout of the paper including the volume, issue and page numbers.

Link to publication

\footnotetext{
General rights rights.

- You may freely distribute the URL identifying the publication in the public portal. please follow below link for the End User Agreement:

www.umlib.nl/taverne-license

Take down policy

If you believe that this document breaches copyright please contact us at:

repository@maastrichtuniversity.nl

providing details and we will investigate your claim.
}

Copyright and moral rights for the publications made accessible in the public portal are retained by the authors and/or other copyright owners and it is a condition of accessing publications that users recognise and abide by the legal requirements associated with these

- Users may download and print one copy of any publication from the public portal for the purpose of private study or research.

- You may not further distribute the material or use it for any profit-making activity or commercial gain

If the publication is distributed under the terms of Article $25 \mathrm{fa}$ of the Dutch Copyright Act, indicated by the "Taverne" license above, 


\title{
CREDIT IN THE ECONOMY: SMALL BUSINESS DEFAULT CORRELATION AND FIRMS CO-MOVEMENTS
}

\section{DISSERTATION}

to obtain the degree of

DOCTEUR DE L'UNIVERSITÉ DU LUXEMBOURG

EN SCIENCES FINANCIÈRES

\author{
AND \\ DOCTOR AT MAASTRICHT UNIVERSITY,
}

on the authority of the Rector Magnificus Prof. dr. Luc Soete in accordance with the decision of the Board of Deans,

to be defended in public in Maastricht, the Netherlands on Wednesday 13 May 2015, at 10.00 hours

by

Magdalena PISA 
Supervisors:

Prof. dr. W.F.M. Bams, Maastricht University

Prof. dr. Christian C.P. Wolff, University of Luxembourg

Assessment Committee:

Prof. dr. Rob Bauer, chairman, Maastricht University

Prof. dr. Theoharry Grammatikos, University of Luxembourg

Dr. Stefanie Kleimeier, Maastricht University

Prof. dr. Ulf Lilienfeld-Toal, University of Luxembourg

Dr. Evren Örs, HEC Paris

Prof. dr. W. Wagner, Tilburg University

Supported by the Fonds National de la Recherche, Luxembourg (project number 970425) and School of Business and Economics. 


\section{Credit in the economy: small business default correlation and firms co-movements}

Magdalena Pisa 
(C) 2015 Magdalena Pisa

All Rights Reserved. No part of this book may be reproduced or utilized in any form or by any means, electronic or mechanical, including photocopying, recording, or by any information storage and retrieval system, without permission in writing from the author.

\section{ISBN 978-99959-0-150-9}

Sowa-Druk na Życzenie

www.sowadruk.pl

tel. 022 431-81-40 


\section{Contents}

1 Introduction 1

2 Credit risk in small business portfolios 5

2.1 Introduction . . . . . . . . . . . . . . . . 5

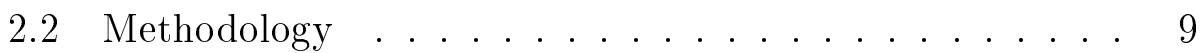

2.3 Data . . . . . . . . . . . . . . . 13

2.4 Results . . . . . . . . . . . . . . . . 16

2.5 Concluding remarks . . . . . . . . . . 30

3 Ripple effects from industry defaults 33

3.1 Introduction . . . . . . . . . . . . . 33

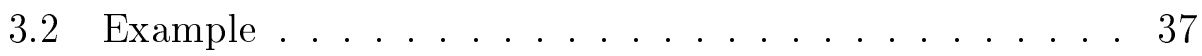

3.3 Related literature . . . . . . . . . . . . . . 40

3.4 Empirical methodology . . . . . . . . . . . . . . 41

3.5 Data . . . . . . . . . . . . . . 44

3.5.1 Dependent variable . . . . . . . . . . . 44

3.5.2 Independent variables . . . . . . . . . . 45

3.5.3 Industry features . . . . . . . . . . . . . . . . 48

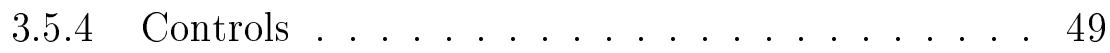

3.6 Main Results . . . . . . . . . . . . . 50

3.6.1 Ripple effects in industry default rates among small manufacturing firms . . . . . . . . 50 50

3.6.2 Ripple effect and market structure ...... . 54

3.6.3 Ripple effect and portfolio loss implication . . . . 60

3.7 Concluding remarks . . . . . . . . . . . 64

4 Trade credit and firm co-movements $\quad 67$

4.1 Introduction . . . . . . . . . . . . . . 67

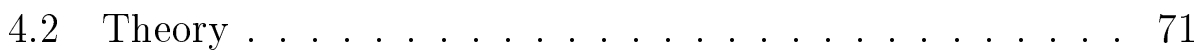

4.3 Empirical approach ................ 74 
4.4 Data ............................. 76

4.5 Application and results ................... 78

4.6 Concluding remarks and discussion ........ 83

5 Conclusions and discussion $\quad 85$

$\begin{array}{ll}\text { A Parameter estimation } & 87\end{array}$

$\begin{array}{ll}\text { B Industry linkages } & 89\end{array}$

$\begin{array}{ll}\text { C Competitive equilibrium } & 91\end{array}$

$\begin{array}{ll}\text { D Taylor expansion } & 93\end{array}$

E Firm level relationship $\quad 95$

$\begin{array}{ll}\text { Bibliography } & 97\end{array}$

$\begin{array}{ll}\text { Knowledge valorization } & 101\end{array}$

$\begin{array}{ll}\text { Nederlandse samenvatting } & 105\end{array}$

$\begin{array}{ll}\text { Curriculum Vitae } & 109\end{array}$ 


\section{Acknowledgements}

During my PhD studies I had the pleasure to meet many inspiring and supportive people. Here I would like to acknowledge their time, devotion and patience in helping me to cross the finish line.

My supervisors, Dennis Bams and Christian Wolff, for stepping in at the beginning of my $\mathrm{PhD}$ studies and guiding me ever since. Under your watch this thesis evolved from a bunch of numbers and figures to its current state.

Special thanks to Jaap Bos for contributing greatly to this thesis. You brought a new perspective to my research. I would like to thank Rob Bauer, Theoharry Grammatikos, Stefanie Kleimeier, Ulf LilienfeldToal, Evren Örs, Wolf Wagner for being part of my assessment committee.

Also, I greatly appreciate advice and support which I received from Ulf Lilienfeld-Toal, Rajnish Mehra and Jos van Bommel in the past months.

I am very fortunate to have the support of seven hard working and incredibly nice women. Déborah Marx, Martine Zenner, Sophie Lux, Emmanuelle Ambroisien, Francien Masthoff, Cècile Luijten and Carina van der Velde, I will always be grateful for all that you have done to help me.

I would like to thank my fellow PhD students at Maastricht University in the Department of Finance and at University of Luxembourg in the Luxembourg School of Finance. You shared my good and bad days, gave me feedback on my thesis and personal life. Special thanks to Gildas Blanchard, Aleksandar Andonov and Lamia Bekkour.

During my PhD I visited Johnson Graduate School of Management at Cornell University. I would like to thank Andrew Karolyi for making it happen.

I would like to thank Dimitris Pongas for making all this possible and my parents for always being there for me. 



\section{Chapter 1}

\section{Introduction}

Small businesses play a crucial role in every developed economy. They are the engine of innovation and economic development. However, small businesses are not as well-researched as their larger counterparts. The main obstacle faced in research of private firms is the absence of publicly available financial statements and market trading. In turn this hinders the possibility to assess properly their individual creditworthiness and the degree of default correlations between them. As correlated defaults can significantly increase levels of losses realized on banks loan portfolios, understanding them is of special interest to banks and financial regulators.

Default correlations can arise as a consequence of exposure to a common factor that affects all firms in the economy. For instance, Basel regulation uses an asymptotic single factor model derived by Vasicek (1987) in modelling default correlations among small business. In this model one common factor drives small business asset prices and ultimately their default rates. Any observed correlations are assumed to be a consequence of firms' exposures to this common factor.

An alternative approach to correlated defaults focuses on interconnections that create such co-movements. In a network economy, idiosyncratic shocks to one firm can be propagated onto its production partners. For instance, Hertzel, Li, Officer, and Rodgers (2008) show that firm bankruptcy is followed by a negative stock price reaction among large public creditors. Kiyotaki and Moore (2002) distinguish two propagation mechanisms in such a network economy: (1) credit chains which form along production processes and can propagate liquidity shocks or (2) fluctuations in collateral prices which can limit financing of credit constrained firms. As argued by Jorion and Zhang 
(2009) observing the credit quality of one firm's production partners is an indication of this firm's future distress.

Apart from creating default clustering, interconnections can generate other co-movements in the economy. For instance, Acemoglu et al. (2012) derives a multi-sector economy in which fluctuations in the economy arise as a result of disaggregated shocks. Until recently it was believed that such disaggregated shocks average out in the aggregate. This point of view, however, ignores the existence of asymmetric interconnections in the economy. Some firms may be more central to the economy as strategic input suppliers or trade credit providers. Shocks to such central firms cannot be compensated for in the aggregate by shocks to more peripheral firms, which in turn generate co-movements in the economy.

To sum up, proper credit risk assessment in small business lending is crucial for banks to estimate their potential losses and for regulators to create appropriate incentives to small business lending. In this dissertation, we ask the following questions: Does Basel regulation address correctly the issue of correlated defaults in small-business loan portfolios? Are industry level production linkages appropriate for creating reliable models, and do these linkages account for correlated default in loan portfolios that do not have information on counterparty exposure, such as portfolios of small business loans? What is the role of trade credit in transmitting idiosyncratic shocks between production partners? The first two studies deal primarily with the issues of correlated defaults among small businesses, while the last study looks at co-movements among production partners which use trade credit.

The first study (in chapter two) addresses issues related to industry heterogeneity, default clustering and parameter uncertainty of capital requirements in US retail loan portfolios. Using a multi-factor model of credit risk, we show that the Basel II capital requirements overstate the riskiness of small businesses. Retail exposures are a much safer investment than the regulations would suggest. The results show that sensitivity to the common risk factors is low and that small business risk is predominantly a reflection of idiosyncratic risk. Only 0.00-3.39\% of asset variability is explained by economy-wide risk factors. The remaining $96.61 \%-100.00 \%$ of small business risk is due to changes in firm-specific characteristics.

Moreover, both expected and unexpected losses are time dependent. Their shifts over the course of financial crisis cause uncertainty regarding the required level of provisions and capital requirements. Im- 
portantly, the estimates of asset correlations are significantly lower than any available estimates for corporate firms. The results are based on a new, representative data set of US small businesses from 2005 to 2011 and they give fundamental insights into the US economy.

Chapter three studies early default risk spillovers to small businesses. This study shows that default rates among small businesses are significantly higher following default on S\&P rated debt in their or their customers' industries. Using a new data set on S\&P rated debt default, small business default, production process linkages and industry characteristics, we find evidence of negative wealth effects transmitted to small businesses along the production process.

Also, such ripple effects are mitigated in loan portfolios that are concentrated into large and highly interconnected industries. We observe that a large number of firms in an industry serves to cushion default risk transmission. This is much like how the broad economic connections offer the benefits of diversification.

Chapter four systematizes the findings of Chapter three in a model of a multi-sector economy. It provides evidence that production linkages, as well as credit chains (represented by trade credit), are important for the transmission of idiosyncratic (firm-level) shocks across firms in the economy. We build on the idea that credit chains develop along production linkages, and amplify the idiosyncratic shock as firms may lack inputs and also liquidity. Using disaggregated firm-level data we show that the disturbance of customer's sales increases with greater trade credit linkage.

We show that during a recession the existence of trade credit linkage propagates shocks upstream, from a supplier onto its upstream customer. In these periods, firms are short of liquidity and are unable to withstand a drop in trade credit provision. In good times, however, trade credit plays a stabilizing role, reducing the volatility of firms' sales. In these periods, firms with sufficient liquidity are able to transfer some of it to liquidity-starved production partners in order to guarantee their own stable production.

In chapter five, we conclude with an overview of the research outcomes presented in this dissertation. 


\section{Chapter 2}

\section{Credit risk in small business portfolios}

\section{$2.1 \quad$ Introduction}

Given the continuously evolving economic conditions in which firms operate, it is unlikely that the loss distribution in a commercial and industrial loan portfolio would remain constant over the years. But a degree of certainty is most often assumed regarding the expected losses covered by loan pricing and provisioning. Uncertainty is in turn associated with the unexpected losses against which financial institutions hold regulatory capital. However, when new information becomes available, expectations about losses shift. We build on the existing literature to include aspects of loan portfolio diversification, dynamics of default risk and capital requirements. Our interest lies in an empirical study of credit risk in portfolios of US retail loans granted to small businesses.

The principal aim of this paper is to provide empirical insights into risk management of US retail loan portfolios. Our contribution to the existing literature is threefold. First, we focus our attention on privately held firms which, although they are very central and important to the US economy, remain difficult to research area due to a lack of financial statements and market trading. As small businesses represent an engine of economic growth and job creation, our findings give fundamental insights into risk sources and dynamics of the US economy. This study employs a unique panel of loans to US private firms from 2005 to 2011, data which captures, among other things, the evolution of small business risk during the turmoil of 2007 to 2009. Secondly, this 
paper discusses whether the regulatory formula captures accurately underlying small business credit risk, or whether it distorts the risk management practices in financial institutions which hold such portfolios. We confirm the existence of capital allocation inefficiencies in US retail loan portfolios arising from the Basel II formula for asset correlation. ${ }^{1}$ Thirdly, we overcome the limited information availability about small businesses by deriving a simple yet effective estimation technique of joint default risks in retail loan portfolios. Importantly for corporate debt portfolios, our estimation technique yields results which are coherent with Basel II capital requirements. Thus, the results for retail loan portfolios can be positioned next to the regulatory ones.

Small businesses in the US are not as well-researched as their larger counterparts. Although they contribute about 50\% to US GDP and employ about $50 \%$ of the private workforce, the available financial information is rather limited. This lack of information stems from the absence of publicly available financial statements, as well as the absence of market trading. Also, until recently most of the information available about this significant segment of the US economy was based on estimates rather than hard data. While some efforts were undertaken to shed light in the area of default dependency in US retail portfolios, these efforts were limited to aggregate measures of small business credit risk (Lee, Wang, and Zhang (2009)) or to loans originated under the US Small Business Administration (SBA) guarantee program (Glennon and Nigro (2005)). Unlike these earlier studies, our study performs an empirical analysis on a new and comprehensive data set on defaults of US private firms, covering a period of seven years from 2005 to 2011 . Our panel contains quarterly observations on small and medium sized firms across all credit ratings and industries in the US, with an average of nearly 240,000 obligors per time period. It provides a unique opportunity to analyze credit risk in retail loans before, during and after the crisis. Note that several non-US studies of small businesses are available: Carling, Rönnegård, and Roszbach (2004) analyze the Swedish retail loan market and Düllmann and Scheule (2003) with their study

\footnotetext{
${ }^{1}$ The Basel II asset correlation formula for retail exposures is used both for the foundation and the advanced IRB approach, in which certain banks can develop their own credit risk models for estimation of default probability, exposure at default and loss given default, respectively. This formula was not subject to any change in Basel 2.5 nor in Basel III. For further details please refer to Basel Committee on Banking Supervision (2006), Basel Committee on Banking Supervision (2009) and Basel Committee on Banking Supervision (2011).
} 
of German small and large firms. Unlike in these studies, we are able to pay attention to the evolution of portfolio risk, as well as to changes in expected and unexpected losses.

The credit risk of small businesses is of particular interest to US financial institutions. As the FDIC reports, US commercial banks' exposure to loans to small businesses is significant, amounting to $24.90 \%$ of all commercial and industrial loans (June, 2011). The large size of the retail loan portfolios and the limited information available on borrower credit worthiness make small businesses of particular relevance for Basel II capital requirements. A discussion of the Basel II capital requirement can also be found in Botha and van Vuuren (2010) and Lopez (2004). The former study asks how asset correlations derived from loss data relate to Basel II and its corresponding capital charges. The latter study reports empirical asset correlations for US, Japanese, and European publicly listed and private firms. Both studies, however, do not pay attention to possible parameter uncertainty in asset correlation and capital requirement estimates. In the context of our study, such uncertainty provides a basis for a prudential approach to capital requirement.

A major aim of our study is to verify the validity of the Basel II minimum capital formulas for US retail loan portfolios. The general setting for our analysis is a multi-factor model. This choice allows us to compare our estimates with the outcomes of the Basel II single-factor model and, at the same time, takes into account an economy with a more advanced structure. In such a multi-factor economy, risks can be industry- or firm-size-specific. This is not possible in the context of Basel II single-factor model. It becomes unnecessary to impose a strong assumption of a single-factor economy. Our multi-factor setting incorporates possible heterogeneity of obligors and risk factors as testable hypotheses. The studies by Dietsch and Petey (2002, 2004) also belong to the sizable family of single-factor models. The former study explores capital requirements in the context of probit and gamma models, as well as deviations from the Basel II Accord, but focuses on French small businesses. The latter study focuses on the nature of asset correlation in small businesses in the French and German markets. Dietsch and Petey (2004) employs a single-factor model. This was extended to multiple common risk factors in 2009. Their generalized linear mixed model assumes that financial institutions possess a considerable set of information about their borrowers, which is typically not the case for US small business. 
As Jorion and Zhang (2009) observe, calibration of portfolio credit risk models from single-factor family is notoriously difficult. However, we suggest a simple estimation technique in which we demonstrate that the observed default frequencies per homogeneous obligor class are sufficient to estimate the joint default risk in a retail loan portfolio. To model and estimate the default dependencies, we begin with the Vasicek (1987) firm value model (explained in Bharath and Shumway (2008) and Gordy (2003)) which demonstrates its applicability to banks' capital requirements. This type of model finds its roots in the work of Merton (1974) and is applied in practice by Credit Metrics (Gupton, Finger, and Bhatia (1997)) and KMV (Crosbie and Bohn (2003)). The advantage of the estimator we suggest lies in the minimal information required to assess the joint default risk in a retail loan portfolio. In fact, our model is of an incomplete information type, as described by Giesecke (2006), in which investors observe a default barrier and obtain noisy reports about a firm's asset value. And although there is not a more sophisticated empirical model of joint default risk, including Duffie, Saita, and Wang (2007), McNeil and Wendin (2007), Duffie et al. (2009), Berndt, Ritchken, and Sun (2010) and Azizpour, Giesecke, and Schwenkler (2012), limited data availability precludes their use for when dealing with the general lack of information regarding small business loans.

In our empirical analysis we address some fundamental questions about how common risk factors are distributed across the economy, and which characteristics are relevant for diversification. We first select the dimensions to assign obligors to homogenous classes. Industries and credit ratings are important criteria in this portfolio segmentation. In general, we find that sensitivity to obligor-class-specific common risk factors remains low and varies between $0.00-18.41 \%$ with only 0.00 $3.39 \%$ of the asset variability explained by common risk factors. The remaining $96.61-100.00 \%$ of small business risk is due to changes in firmspecific characteristics. During the whole period analyzed the implied asset correlation averages around $0.41 \%$. Regardless of the riskiness of a small business, industry or firm size, our estimates are significantly lower than any available estimate for large firms. Our estimates imply that a single-factor model, as assumed by Basel II capital calculations, is too simplistic to summarize the entire structure of the US economy. In fact the US economy displays more signs of complexity and has more relevant sources of risk than a nation-wide single-factor.

Next, we analyze how the riskiness of US small business has evolved 
over the course of the financial crisis. Two important elements of default risk are present in a loan portfolio: expected and unexpected losses. We find that the firms which withstood the crisis showed less sensitivity to economic conditions, a substantial reliance on the firm's characteristics and lower default clustering from exposure to macroeconomic events. The importance of firm-specific risk as a source of default risk was also discussed in Jarrow and Yu (2001), who link it to a firm's individual business connections.

Lastly, we compare our results with Basel II capital requirement calculations, which imply a substantially larger exposure of retail loan portfolios to common risk factors. We observe a sizable overstatement of retail debt risk as perceived by the Basel II compared to our method. In our view this difference stems from the overly simplistic way in which Basel II models and estimates asset correlations in retail loan portfolios. In fact, our results show that, from a credit risk perspective, retail exposures are safer investments than the regulations would suggest. We summarize the empirical results by discussing the parameter uncertainty of our estimates. A prudential adjustment of the capital requirements can be achieved by accounting for parameter uncertainty, but also by allowing for fat-tail distributed risk factors. Such adjustment aims to provide a better understanding of the results presented in this study for risk management purposes.

The paper is organized as follows. The next section introduces a probabilistic model of joint default risk and its proposed estimators. Section 2.3 outlines the D\&B data set of small US businesses. The empirical results for the pre-, during and post-crisis phases are presented in section 2.4, which also summarizes the implications of our findings for risk management and capital requirements in financial institutions. Section 2.5 concludes.

\subsection{Methodology}

We generalize the existing asymptotic single-factor model to a multifactor model which includes aspects of diversification and segmentation. The model used departs from the Basel II asymptotic single risk factor in that we allow flexibility in the number of risk factors in the economy (i.e. a common factor per obligor class) as opposed to a single global risk factor. This general framework finds empirical support in the next section. Industry-related heterogeneity and multiple common 
risk factors in the US economy find support in the data. Our model is equivalent to the regulatory model if we observe perfectly correlated common risk factors and yield estimates consistent with those used for the regulation.

Consider a portfolio of $N$ small obligors which are ordered into homogeneous obligor classes $k \in\{1, \ldots, K\}$. This set of homogeneous obligor classes is categorized with respect to firm's credit worthiness, industry, etc. Let latent variable $A_{i, t}$ denote the asset value of obligor $i$ in obligor class $k$ at time $t$ which without loss of generality is standardized and centered around zero. The asset value is driven by two independent components: a common risk factor $x_{k, t}$ per obligor class $k$ and an idiosyncratic risk factor $\epsilon_{i, t}$ per obligor $i$ :

$$
A_{i, t}=w_{k} x_{k, t}+\sqrt{1-w_{k}^{2}} \epsilon_{i, t} \quad i \in k \quad t=1, \ldots, T
$$

where $\mathrm{E}\left[x_{k, t} \epsilon_{i, t}\right]=0$. The class-specific common risk factor $x_{k, t}$ represents changes in the economic conditions common to all obligors in obligor class $k$ and the idiosyncratic risk factor $\epsilon_{i, t}$ stands for firmspecific risk attributed to each obligor. The weight $w_{k}$ of the common risk factor measures the sensitivity of obligor $i$ to its economic conditions. Given that any two firms classified into the same obligor class are sufficiently homogeneous, it is customary to assume that the classspecific factor has an identical effect on these firms' asset values (McNeil and Wendin (2007), Gordy (2000)). It follows that the weight $w_{k}$ is the same for obligors in one obligor class. Credit portfolio concentration risk depends heavily upon the magnitude with which obligors' asset values respond to the common risk factor. The higher the firm's sensitivity to the common risk factor, the more responsive the asset value to unanticipated changes in the economic environment. In fact, the default dependency in a loan portfolio arises from co-movements in asset values that is induced by those common risk factors' correlation across obligor classes, with a correlation matrix $\Omega$, where:

$$
\Omega_{k l}=\operatorname{Corr}\left[x_{k}, x_{l}\right]
$$

Empirically, time variation in the sensitivity $w_{k}$ can be achieved by applying a moving-time-window technique. By shifting the time windows for pre-, during- and post-crisis phases we are able to investigate changes in the sensitivity $w_{k}$ over time.

At the beginning of each period $t$, the cohort consists of $N_{k, t}$ obligors in non-defaulted state. However, this state of obligor $i$ can be subject to 
change and it depends on a relative distance of obligor's asset value (2.1) to a threshold that defines the default event. We assume that $x_{k, t}$ and $\epsilon_{i, t}$, and hence the asset value, are standard normally distributed. The default threshold is equal to $\Phi^{-1}\left(\bar{p}_{k}\right)$ where $\Phi^{-1}(\cdot)$ denotes the standard normal CDF and $\bar{p}_{k}$ stands for the unconditional probability of default in obligor class $k$. Our model shares the definition of the default event with the structural models that date back to work of Merton (1974) and Black and Cox (1976). In this framework an obligor $i$ defaults if:

$$
w_{k} x_{k, t+1}+\sqrt{1-w_{k}^{2}} \epsilon_{i, t+1}<\Phi^{-1}\left(\bar{p}_{k}\right) \quad \Leftrightarrow \quad D_{i, t+1}=1
$$

where $D_{i, t+1}$ denotes a default indicator of firm $i$. By definition $D_{i, t+1}$ takes value 1 if firm $i$ defaults at time $t+1$ and 0 otherwise. Because we are interested in joint default occurrences, i.e. obligors simultaneously going into default, for the default assessment at time $t+1$ we exclude contracts that are in default at time $t$. From (2.3) it follows that if the economic conditions $x_{k, t}$ are good, a firm defaults only if the realization of the idiosyncratic risk factor $\epsilon_{i, t}$ is worse. Also, the asset correlation between two obligors $i$ and $j$ is:

$$
\rho_{i j}=\operatorname{Corr}\left[A_{i, t}, A_{j, t}\right]=w_{k} w_{l} \Omega_{k l} \quad i \in k, j \in l
$$

From the above relationship one can see that, keeping $\Omega$ constant, with an increase in $w$ the obligors become more strongly correlated, but with a decrease in the sensitivity parameter it is the idiosyncratic risk that dominates.

In this setup we derive the theoretical moment for the joint probability of default to be equal to the probability of two obligors being simultaneously below the default threshold (for a derivation, please refer to Appendix A). Hence, the joint probability of default of obligors $i$ and $j$ follows as:

$$
\begin{aligned}
p_{k l} & \equiv P\left[D_{i, t+1}=1, D_{j, t+1}=1\right] \\
& =\int_{-\infty}^{\Phi^{-1}\left(\bar{p}_{l}\right)} \Phi\left(\frac{\Phi^{-1}\left(\bar{p}_{k}\right)-\Omega_{k l} w_{k} w_{l} y}{\sqrt{1-\Omega_{k l}^{2} w_{k}^{2} w_{l}^{2}}}\right) \frac{1}{\sqrt{2 \pi}} \exp \left(-\frac{1}{2} y^{2}\right) d y
\end{aligned}
$$

where obligor $i$ belongs to obligor class $k$ and obligor $j$ belongs to obligor class $l$. The empirical analysis focuses on estimation of the parameter set $\theta \equiv(w, \Omega)$ where $w \equiv\left(w_{1}, \ldots, w_{K}\right)$ denotes the vector of common risk factors sensitivities and $\Omega$ represents the matrix of common risk 
factor correlations. The proposed method of moments estimation for credit risk is compatible with a statistical analysis of obligors clustered into obligor classes.

Equation (2.6) is at the center of the estimation procedure. The left hand side of the equation gives the theoretical moment for the joint probability of default that is caused by the aggregate behavior of obligors in an obligor class. Next, we minimize the distance between this theoretical moment and its sample counterpart. Denote an observed default frequency in obligor class $k$ at time $t$ by $O D F_{k, t}$. It follows that the observed default frequency is equal to a ratio of all default events in obligor class $k$ to the total number of obligors in this class $O D F_{k, t}=\sum_{i \in k}^{N_{k, t}} D_{i, t+1} / N_{k, t}$. It can be shown (see Appendix A) that for two obligor classes $k$ and $l$, the sample joint probability of default corresponds to a historical average of products of their observed default frequencies. As a result, the following relationship holds for the joint probability of default for two obligors $i$ and $j$ in obligor classes $k$ and $l$ respectively:

$$
\hat{p}_{k l}=\frac{1}{T} \sum_{t=1}^{T}\left(O D F_{k, t} \cdot O D F_{l, t}\right)
$$

We refer to the expression in (2.6) as the between obligor class sample moment since it depicts the joint probability of default for obligors in two different obligor classes. By analogy, the within obligor class sample moment for the joint probability of default for two obligors in the same obligor class $k$ follows as:

$$
\hat{p}_{k k}=\frac{1}{T} \sum_{t=1}^{T}\left(O D F_{k, t} \cdot O D F_{k, t}\right)
$$

Our estimate of $w$ follows from method of moments applied to equation (2.6) using the sample moments in (2.7). The vector $w$ that is obtained is used in the next step to estimate $\Omega$ from equations (2.6) and (2.6). ${ }^{2}$ Importantly, only minimal information on the obligor class level is required to estimate the relevant parameter vector $\theta$, namely the observed default frequencies per obligor class. Moreover, this information is usually readily available within a loan-granting financial institution, which facilitates easy application of the approach proposed by small business finance providers. The advantage of the multi-factor

\footnotetext{
${ }^{2}$ Essentially it is a numerical optimization which minimizes the sum of squared errors between the population and sample moments over a domain $\theta$.
} 
model over a single-factor one is more realistic modeling of portfolio risk. Thus, by estimating $\Omega$ from the between obligor class moments one obtains a more comprehensive view of the portfolio risk, its diversification possibilities and a more informed segmentation of exposures. Interestingly, the single-factor model is estimated based solely on subportfolios composed of homogeneous obligors, which is equivalent to estimation of the within obligor class moments (see Gordy (2000), Dietsch and Petey $(2002,2004))$.

Furthermore, this multi-factor model collapses into a single-factor in case of perfectly correlated common risk factors. It follows that the common risk factor $x$ is one-dimensional (as assumed in Gordy (2003)). In other words, the perfect correlation imposes a single common risk factor as the sole external source of default correlation. The above property can be used to test the single-factor assumption and homogeneity of obligors with obligor class.

\section{$2.3 \quad$ Data}

In this section we outline the main characteristics of a unique data set provided by Dun \& Bradstreet. The data set contains information about 500,000 US small firms that were active between 2005 and 2011 at different points in time. Our analysis is free of selection bias and includes, on average, nearly 240,000 firms across all credit ratings, industries and firm sizes in the US. This represents a cross section of the US economy.

The D\&B data set contains rich quarterly information on firms' actual borrowing and payment behavior, public detrimental information (such as county court judgments), legal pre-failure events (receivership, bankruptcy, etc.), credit ratings but also legal form, age, industry and the firm's location. The sample covers about $\$ 19$ billion of annual small business financial activity, providing a representative outlook of the economy. The average credit outstanding per firm is $\$ 31,860.33$ with $24.49 \%$ of the exposure below $\$ 1,000$ and $99.75 \%$ below $\$ 1$ million. The information coverage of the US economy is substantial, with about 6,000 major firms (both financial and non-financial) reporting to D\&B. It includes loan and trade records stored by financial institutions and vendors. We use the Basel Accords definition in which a default takes place if a payment is 90 days past due or unlikely to be paid. Thus, at the end of each quarter and for each active non-defaulted firm, we 


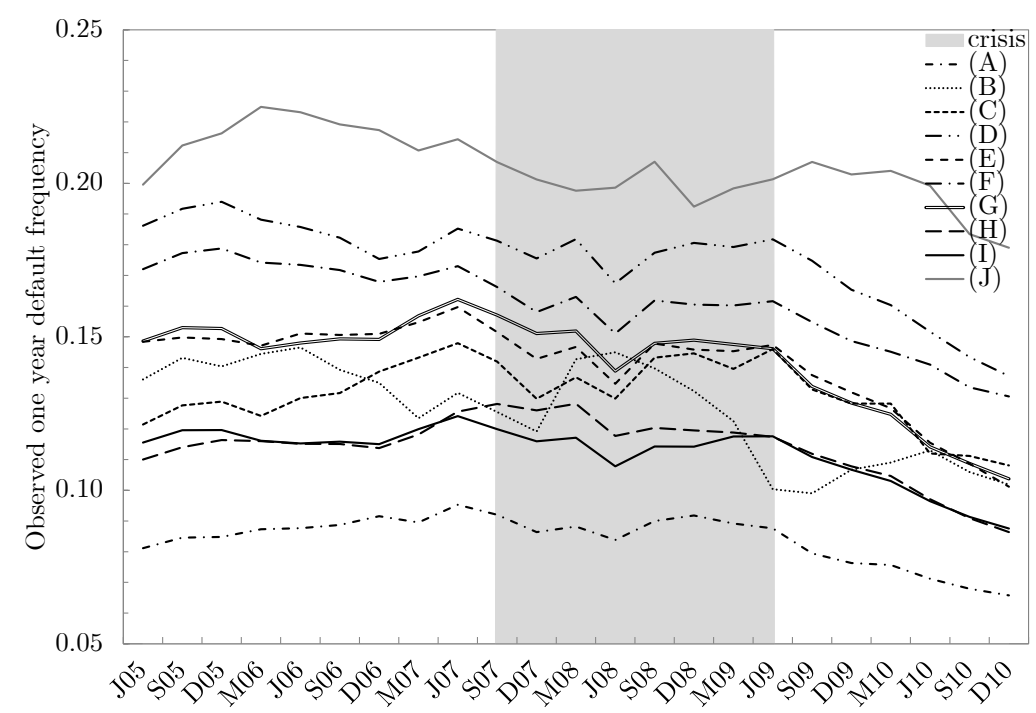

Figure 2.1: Observed default frequencies per industry classes. The shadowed area illustrates the crisis phase as defined by NBER business cycle reference dates. The pre-crisis phase covers June 2005 till September 2007; crisis is from December 2007 until June 2009 and post-crisis phase covers September 2009 until December 2010.

observe the firm's characteristics and whether over the year the firm has payments due for more than 90 days or written off, whether it goes bankrupt, or is downgraded to credit score 0 (default).

A review of the business size reveals that firms represent all major US industries with a high concentration in services $(40.78 \%)$, retail trade $(14.82 \%)$ and construction $(13.61 \%)$. Aside from the nonclassified firms, it is manufacturing that experiences the highest default rate of $17.48 \%$, which is also illustrated in Figure 2.1. In the context of recession this high default rate is explained by consumers tending to abstain from new purchases and to repair the equipment they already own (consistent with lower default rate in services). In this sample $56.59 \%$ of firms have fewer than five employees and $98.29 \%$ have fewer than 100 employees. Surprisingly, very small firms seem to perform better on average than small or medium-sized firms. Table 2.1 reports that the annual default rate increases with firm size from $9.67 \%$ for very small firms (up to five employees) to $35.98 \%$ for those which employ more than 100 people. Similar results can be found in Glennon and Nigro (2005) who also report higher default rates for larger firms. The observed regularity can be due to higher cash holdings in very small businesses which create a buffer for financial distress (Steijvers and Niskanen (2009)). 
Table 2.1

\section{Small businesses in the US}

Descriptive statistics for US small businesses in the D\&B data set covering period from 2005 to 2011. The values: number of firms, \% total and default rate (\%) represent a historical average. Agri denotes Agriculture, Forestry, Fishing; Mining denotes Mining; Constr denotes Construction; Mfg denotes Manufacturing; Trans denotes Transportation, Communications, Electric, Gas, and Sanitary Services; Wholes denotes Wholesale Trade; RetlTrd denotes Retail Trade; FIRE stands for Finance, Insurance, and Real Estate; Service for Services and PA for Public Administration and non-classified. Geographic regions are defined as: Central: IA, KS, MN, MO, NE, ND, SD; West: AK, AZ, CA, CO, HI, ID, MT, NV, NM, OR, UT, WA, WY; Northeast: CT, ME, MA, NH, NJ, NY, PA, RI, VT; Midwest: IL, IN, MI, OH, WI; Southeast: DE, DC, FL, GA, MD, VA, NC, SC, WV, AL, KY, MS, TN; Southwest: AR, LA, TX, OK.

\begin{tabular}{|c|c|c|c|c|c|c|}
\hline \multirow{2}{*}{\multicolumn{2}{|c|}{ 1. SIC industry division }} & \multirow[t]{2}{*}{ \# firms } & \multirow[t]{2}{*}{$\%$ total } & \multirow[t]{2}{*}{$\min$} & \multirow[t]{2}{*}{$\max$} & defaults (\%) \\
\hline & & & & & & \\
\hline & Agri & 9,902 & 4.19 & 9,340 & 10,188 & 8.39 \\
\hline & Mining & 825 & 0.35 & 758 & 872 & 12.55 \\
\hline & Constr & 32,180 & 13.61 & 27,048 & 36,275 & 13.13 \\
\hline & Mfg & 16,382 & 6.93 & 14,155 & 18,278 & 17.48 \\
\hline & Trans & 8,123 & 3.44 & 6,963 & 9,046 & 14.12 \\
\hline & Wholes & 16,048 & 6.79 & 14,063 & 17,836 & 16.02 \\
\hline & RetlTrd & 35,032 & 14.82 & 29,552 & 39,993 & 14.19 \\
\hline & FIRE & 20,020 & 8.47 & 17,170 & 22,310 & 11.34 \\
\hline & Service & 96,379 & 40.78 & 85,672 & 104,065 & 11.19 \\
\hline & PA & 1,467 & 0.62 & 1,358 & 1,831 & 23.88 \\
\hline \multicolumn{7}{|c|}{ 2. $\quad$ Firm size } \\
\hline & $1-5$ & 133,755 & 56.59 & 115,434 & 147,547 & 9.67 \\
\hline & $6-10$ & 44,125 & 18.67 & 38,308 & 49,158 & 12.89 \\
\hline & $11-20$ & 28,244 & 11.95 & 24,731 & 31,174 & 15.82 \\
\hline & $21-30$ & 10,890 & 4.61 & 9,778 & 11,867 & 18.53 \\
\hline & $31-50$ & 9,150 & 3.87 & 8,344 & 9,904 & 21.16 \\
\hline & $51-100$ & 6,149 & 2.60 & 5,670 & 6,751 & 26.42 \\
\hline & $>100$ & 4,043 & 1.71 & 3,700 & 4,446 & 35.98 \\
\hline \multicolumn{7}{|c|}{ 3. \$ outstanding } \\
\hline & $\$ 0-500$ & 38,530 & 16.30 & 29,436 & 48,676 & 5.78 \\
\hline & $\$ 501-1,000$ & 18,648 & 7.89 & 15,510 & 24,119 & 7.57 \\
\hline & $\$ 1,001-2,000$ & 22,880 & 9.68 & 19,990 & 27,531 & 9.15 \\
\hline & $\$ 2,001-5,000$ & 32,174 & 13.61 & 29,208 & 35,538 & 10.94 \\
\hline & $\$ 5,001-15,000$ & 48,536 & 20.54 & 42,366 & 52,458 & 12.67 \\
\hline & $\$ 15,001-30,000$ & 28,001 & 11.85 & 24,930 & 31,288 & 14.73 \\
\hline & $>\$ 30,001$ & 47,589 & 20.13 & 38,951 & 53,303 & 22.23 \\
\hline \multicolumn{7}{|c|}{ 4. Region } \\
\hline & Central & 17,512 & 7.41 & 16,135 & 18,876 & 10.65 \\
\hline & West & 53,754 & 22.74 & 45,590 & 59,743 & 12.84 \\
\hline & Northeast & 49,437 & 20.92 & 43,212 & 54,240 & 12.37 \\
\hline & Midwest & 36,319 & 15.37 & 32,368 & 39,741 & 12.31 \\
\hline & Southeast & 55,219 & 23.36 & 47,174 & 61,552 & 14.00 \\
\hline & Southwest & 24,118 & 10.20 & 21,533 & 26,437 & 12.62 \\
\hline \multicolumn{7}{|c|}{ 5. Private } \\
\hline & Yes & 236,284 & 99.97 & 206,140 & 260,471 & 12.74 \\
\hline & No & 74 & 0.03 & 50 & 117 & 42.58 \\
\hline & & 236,358 & 100.00 & 206,196 & 260,590 & 12.74 \\
\hline
\end{tabular}

With the vast majority of records containing information on privately held firms $(99.97 \%)$ this study sheds light on the private small business economy. The firms analyzed are located in all major US re- 
gions with a higher concentration in California in the West, Texas in the Southwest and New York in the Northeast, representing 12.09\%, $6.74 \%$ and $6.56 \%$ of the population, respectively.

The homogeneous obligor classes are differentiated with respect to three criteria: credit rating, industry and firm size. For purpose of our study we adopt the D\&B credit evaluation points (CPOINTS) as an indicator of firm's credit worthiness. On this basis we construct credit ratings as percentiles of the whole distribution such that the credit rating " 1 " contains the $10 \%$ most credit worthy obligors and credit rating " 10 " the $10 \%$ least credit worthy obligors. The accuracy ratio of the credit rating is $19.20 \%$. The discriminatory power of this rating is highly significant, which is confirmed by Kolmogorov-Smirnov and Mann-Whitney U tests (not shown).

We categorize the firms into sets of homogeneous obligor classes based on their credit ratings and ten major SIC industry divisions. But in the absence of industry classification, financial institutions may turn to other available information to classify their exposures. Hence we conduct the analysis for credit ratings and seven firm size classes which are differentiated with respect to their number of employees. Those seven firm size classes include very small firms with less than five employees, or those which employ 6-10, 11-20, 21-30, 31-50, 51-100 or more than 100 individuals.

\subsection{Results}

In this section the estimator we suggest is applied to the data set described in the previous section. Particular interest is paid to the role of industry and firm size in shaping the risk in loan portfolios. We test the validity of the single-factor assumption in retail portfolios. Also, we discuss aspects of expected and unexpected losses, default clustering and compare our results to the Basel II minimum capital requirements.

The empirical analysis begins by identifying the relevant risk factors in loan portfolios. We look at conventional factors such as credit rating and firm size (Basel II) and some unconventional ones such as industry. Next, firms' reactions to the factor determine whether it is a relevant risk factor. If firms react in a homogeneous way to the factor, it does not have significant additional risk content. If, however, the reaction is heterogeneous, we uncover a relevant additional risk factor. In the multi-factor setting, homogeneity is defined as a situation in which firms 
from the same obligor class have equal sensitivity parameters w even if further segmented into smaller subclasses.

In practice credit ratings often serve to identify the homogenous obligor classes. It is a procedure which separates the firms according to their distribution with respect to risk. Hence for purpose of the study we select the credit rating as the primary dimension of the analysis, and subsequently subdivide into industry or firm-size categories. Dietsch and Petey (2009) and McNeil and Wendin (2007) underline the relevance of other sources of heterogeneity than credit rating such as industry. Their claim is that a specialization in financing to a specific industry may question the capital requirements based solely on credit rating, and hence should include industry characteristics as well. The results of their study are based on corporate exposures. In small businesses we find some support for this hypothesis, which can be seen in Table 2.2. The table reports point estimates of the sensitivities to the common risk factors $w_{k}$ for firms classified with respect to both credit rating and industry, but also estimates for credit ratings only and for industries only. Indeed, the sensitivities to common risk factors per credit rating are not affected by the industry related heterogeneity. The inverse holds true as well. Thus, all credit ratings in one industry react in a similar fashion to a change in common risk factors.

On the other hand, the industry related heterogeneity in credit ratings is revealed as different common risk factors per obligor class. Table 2.4 presents Jennrich (1970) tests for equality of correlation matrices where the reference matrix is equal to a matrix of ones hence a perfect correlation matrix. Panel A shows significant evidence of industry heterogeneity in the common risk factors. Only credit rating 4 and 9 remain robust to the industry related heterogeneity. This is good news for portfolio risk management as the industry-related heterogeneity gives rise to diversification benefits that stem from lower correlations between the common risk factors. Consider for a moment the whole economy categorized into industries. Each of those industries consists of firms from various credit ratings. Panel $\mathrm{C}$ in Table 2.4 shows this credit rating has a significant source of heterogeneity within a given industry. Interestingly, only the finance industry remains homogeneous. This homogeneity is present notwithstanding the very distinctive risk factors which influence firms in the finance industry and regardless of the credit rating, i.e. money provision, regulation or credit cycle.

In addition to industry, heterogeneity within credit rating arises typically related to firm size. Intuitively, micro-firms which are great in 


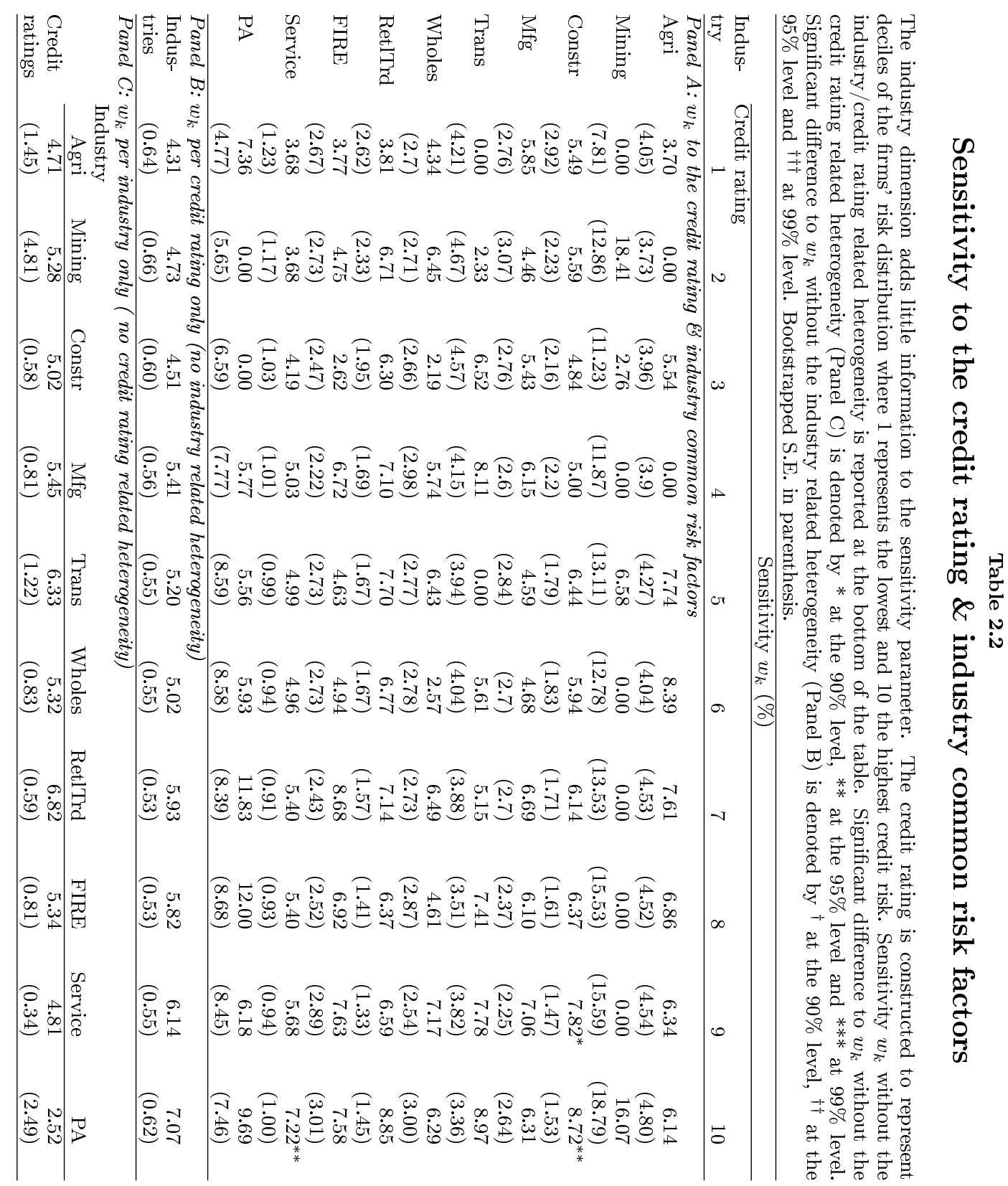




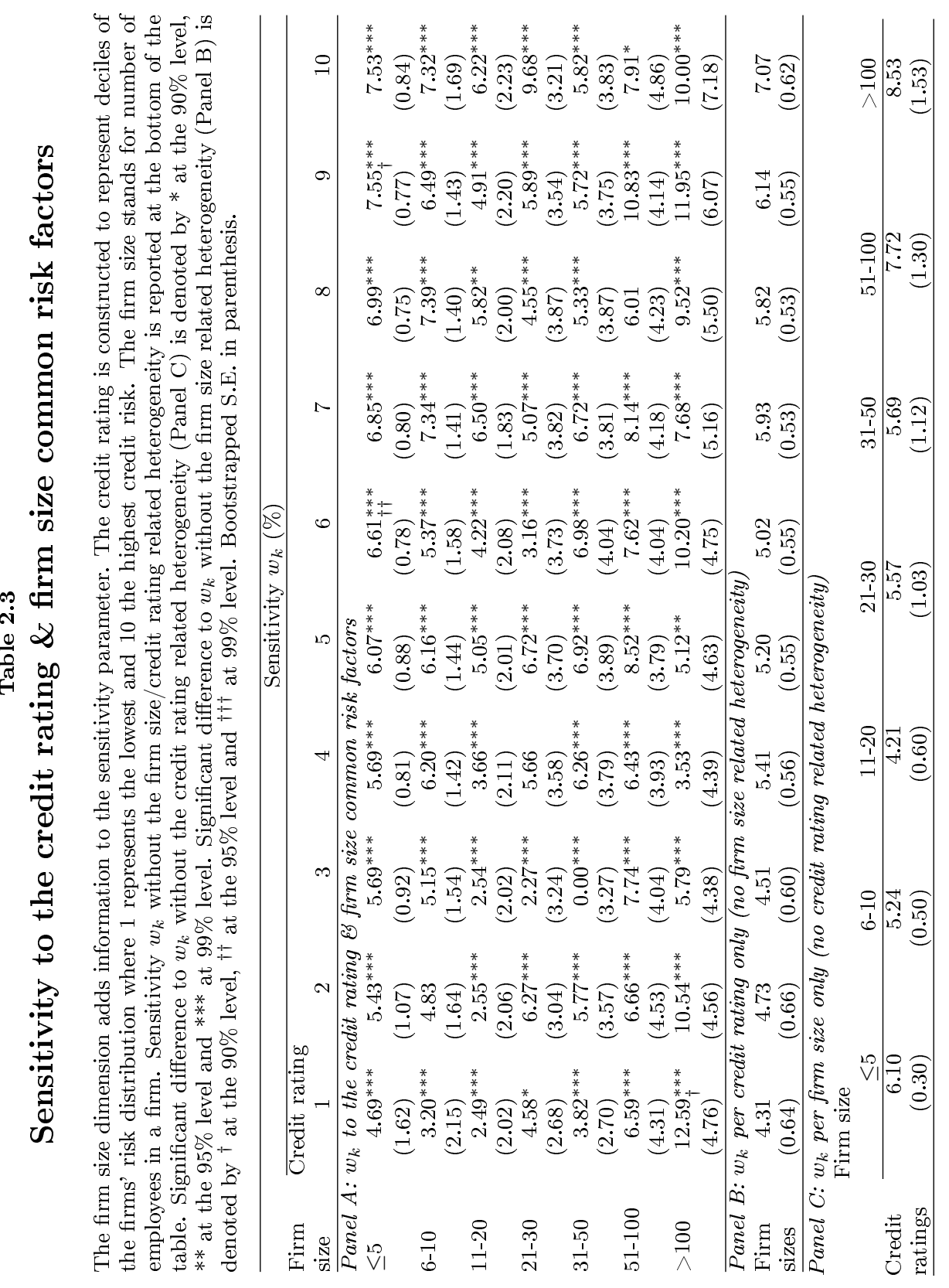


Table 2.4

\section{Homogeneity of credit rating/industry/firm size common risk factors}

Jennrich (1970) test for equality of correlation matrices. It tests the difference between an estimate of a partition of (common risk factors) correlation matrix $\Omega$ and a matrix of ones. The partitioning is done according to the dimension tested for homogeneity. Thus if the homogeneity within credit rating is analyzed, the $\Omega$ is broken in such way that only the correlations within a given credit rating remain.

\begin{tabular}{|c|c|c|c|c|c|c|c|c|c|c|}
\hline \multicolumn{11}{|c|}{ Credit rating } \\
\hline & 1 & 2 & 3 & 4 & 5 & 6 & 7 & 8 & 9 & 10 \\
\hline \multicolumn{11}{|c|}{ Panel A: Industry related homogeneity in credit rating } \\
\hline$\chi^{2}$ & 138.37 & $21 \cdot 10^{28}$ & 110.28 & 29.03 & 104.401 & 953.50 & 228.35 & 785.00 & 35.98 & 168.43 \\
\hline$d f$ & 45 & 45 & 45 & 45 & 45 & 45 & 45 & 45 & 45 & 45 \\
\hline$p$-value & 0.00 & 0.00 & 0.00 & 0.97 & 0.00 & 0.00 & 0.00 & 0.00 & 0.83 & 0.00 \\
\hline \multicolumn{11}{|c|}{ Panel $B: \overline{\text { Firm size related homogeneity in credit rating }}$} \\
\hline$\chi^{2}$ & 24.29 & 15.62 & 771.52 & 68.69 & 44.801 & 061.80 & 214.94 & 113.01 & 189.32 & 14.88 \\
\hline$d f$ & 21 & 21 & 21 & 21 & 21 & 21 & 21 & 21 & 21 & 21 \\
\hline$p$-value & 0.28 & 0.79 & 0.00 & 0.00 & 0.00 & 0.00 & 0.00 & 0.00 & 0.00 & 0.83 \\
\hline
\end{tabular}

\begin{tabular}{|c|c|c|c|c|c|c|c|c|c|c|}
\hline \multicolumn{11}{|c|}{$\begin{array}{c}\text { Panel C: Credit rating related homogeneity in industry } \\
\text { Industry }\end{array}$} \\
\hline \multirow{3}{*}{$\chi^{2}$} & Agri & Mining & Constr & Mfg & Trans & Wholes & RetlTrd & FIRE & Service & PA \\
\hline & 448.66 & 621.77 & 770.89 & \multirow{2}{*}{\multicolumn{2}{|c|}{$678.616,098.10$}} & $253 \cdot 10^{3}$ & & \multirow{2}{*}{\multicolumn{2}{|c|}{$11.352,429.40$}} & 2.42 \\
\hline & & & & & & \multicolumn{2}{|c|}{$7,805 \cdot 10^{4}$} & & & \\
\hline$d f$ & 45 & 45 & 45 & 45 & 45 & 45 & 45 & 45 & 45 & 45 \\
\hline$p$-value & 0.00 & 0.00 & 0.00 & 0.00 & 0.00 & 0.00 & 0.00 & 1.00 & 0.00 & 1.00 \\
\hline
\end{tabular}

\begin{tabular}{lrrrrrrr}
\hline Panel D: Credit rating related homogeneity in firm size \\
& Firm size & & & & & \\
& $\leq 5$ & $6-10$ & $11-20$ & $21-30$ & $31-50$ & $51-100$ & $>100$ \\
$\chi^{2}$ & 149.81 & 480.08 & $13 \cdot 10^{5}$ & 4.62 & 179.24 & 47.09 & 4.48 \\
$d f$ & 45 & 45 & 45 & 45 & 45 & 45 & 45 \\
$p$-value & 0.00 & 0.00 & 0.00 & 1.00 & 0.00 & 0.39 & 1.00 \\
\hline
\end{tabular}

number, should operate in a almost perfectly competitive environment, while larger firms could benefit from market power. Table 2.3 shows the sensitivity to common risk factors for obligor classes separated with respect to credit rating and firm size. With respect to these sensitivity parameters, we find strong evidence of firm-size related homogeneity in credit ratings. On the other hand, if the segmentation would have been implemented only according to firm size, the assumption of class homogeneity would have been violated. Thus, the credit rating contains significant information about the sensitivities to common risk factors, but not the firm size. Panels B and panel D in Table 2.4, however, find only moderate support for homogeneity across the credit rating and firm size common risk factors. From a risk management perspective this allows for some diversification benefits.

This redundancy of firm size factor favors credit rating and industry as relevant risk factors. Moreover, our results do not support the con- 
ventional wisdom of Basel II according to which firm size determines the level of risk. Instead, we find that firms react to the size factor in a homogenous way, making this dimension redundant. Also, Basel II assumes a strictly decreasing asset correlation function in the dimensions of credit rating and firm size (Basel Committee on Banking Supervision (2005)). To the contrary, we find a non-monotonic relationship between firm size and asset correlation that is inconsistent with the Basel II formula for minimum capital requirements.

A large proportion of the existing literature (i.e. Gordy (2000, 2003), Lopez (2004)) and regulatory frameworks such as Basel II (Basel Committee on Banking Supervision (2005)) assumes a single-factor model. This assumption translates into a situation in which only a single economy-wide common risk factor exists and all obligors are subject to changes therein. It is counter-intuitive that all industries would depend on identical risk factors which strike at the same time, with the same strength. It is hard to believe that weather-risk associated with the agricultural industry, demographic risk with the construction industry, oil price risk with the transport industry, or liquidity risk associated with the finance industry are all perfectly correlated.

Next we formally test for the presence of one common factor. In terms of our model in which the correlation matrix $\Omega$ is estimated in an unconstrained manner, we statistically test for a single risk factor if all common risk factors were perfectly correlated. In order to test the validity of this simplifying assumption for US small businesses we use Jennrich (1970) test for equality of correlation matrices. The test results are shown in Table 2.5. Our results call into question the assumption of a single common risk factor in US retail portfolios. This assumption is violated for the obligors segmented according to their credit rating and industry. As expected, those two dimensions capture some of information differentiating obligors' risk types. However, there is no empirical evidence in favor of the second type of segmentation organized according to credit rating and firm size. We find those dimensions redundant where risk factors are perfectly correlated. In view of these results we create homogenous obligor classes with respect to two criteria: credit rating and industry.

Next, we attempt to answer the question of which risk dominates for small businesses: systematic or idiosyncratic. Given that small businesses represent a significant part of the US economy, one might expect that their aggregate behavior follows the swings in the economy as a whole. On the other hand each small business has individual quali- 
Table 2.5

\section{Single vs. multi-factor model}

There is support for industry to be a relevant risk factor but not for firm size. The firm size factor collapses to a single factor. This result questions Basel II approach featuring firm size as a risk factor. The table reports Jennrich (1970) test for equality of correlation matrices. It tests the difference between an estimate of common risk factors correlation matrix $\Omega$ and a matrix of ones. The obligor classes are divided with respect to credit rating and industry, or credit rating and firm size.

\begin{tabular}{lrrr}
\hline & Credit rating \& industry & Credit rating \& firm size \\
\cline { 2 - 3 } \cline { 3 - 3 }$\chi^{2}$ & $63,086.00$ & 982.53 \\
$d f$ & 4950 & 2415 \\
$p$-value & 0.00 & 1.00 \\
\hline
\end{tabular}

ties and attributes, such as location, business network, faithful clients etc. that are relatively stable over the business cycle and these factor are often decisive. A bakery on the corner or a dentist downtown can do fine even during recession. Table 2.2 shows that across the whole sample period small businesses have a tendency to manifest significant idiosyncratic risk. The direct obligor's characteristics that are often decisive for the success or failure of the small business (see also Phelan (2011)) show up significantly in Table 2.2. Even though the sample period covers a whole business cycle, with expansion in 2005 to 2006 , recession in 2007 to 2009 and recovery in 2010, we observe that the estimated sensitivities to the common risk factors remain low and vary between $0.00-18.41 \%$ explaining only $0.00-3.39 \%$ of the asset variability. The remaining $96.61-100.00 \%$ of small business risk is due to changes in the firm-specific characteristics. ${ }^{3}$ These results are striking, especially in the light of the crisis which affected the whole economy with very few exceptions. Although the probabilities of default were on average high during the crisis, the uncertainty about default decreased in that it almost became more of a certainty. A second reason for finding low sensitivity of US small business to systemic risk factor stems from the data set being quasi-exhaustive and approaches the limits of diversification in the US economy. As Dietsch and Petey (2004) we believe financial institutions observe higher asset correlations in their portfolios

\footnotetext{
${ }^{3}$ The low values of sensitivity parameters $w_{k}$ remain robust to changes in the default definition to a less conservative one (which considers only loss events acquired by a debt holder). Also, for US geographic regions, the values of sensitivity parameters $w_{k}$ remain low. Intuitively, it is expected that geographic proximity in the activity of small businesses would cause them to be more susceptible to common risk factors. However, the results for US states show that the idiosyncratic risk in small business loans prevails.
} 
due to possible further diversification on their books.

On the asset correlation side, presented in Table 2.6, we find that during the whole period analyzed, implied asset correlation averaged around $0.41 \%$, with the lowest values of $0.00 \%$ for mining and agriculture and a statistically significant highest value of $0.78 \%$ for the retail trade businesses. Most importantly, regardless of the small business' riskiness and industry, our estimates are significantly lower than any available estimate for larger firms. For example, McNeil and Wendin (2007) report asset correlations between larger firms ranging from $6.30 \%$ $10.90 \%$. That is fifteen to twenty-six times more than our average estimate for small businesses. These considerably lower asset correlations between small businesses have important regulatory consequences, which are discussed further in this section.

We now turn our attention to the development of small business riskiness over the course of the recent financial crisis. For this purpose we apply a moving window technique in which the overall sample period is subdivided into three phases according to NBER business cycle reference dates. First phase: pre-crisis, covers June 2005 till September 2007. The crisis phase is from December 2007 until June 2009 and the post-crisis phase covers September 2009 until December 2010. This subdivision allows us to estimate the model separately in those three phases and to focus on changes of joint default risk. Figure 2.2 addresses two important elements of default risk in a portfolio of loans: expected and unexpected losses. Both of these are expected to vary over the different phases of the crisis. Expected losses are associated with the probabilities of default, as illustrated in Panels a, c and e. Unexpected losses associated with asset correlations, as is illustrated in Panels b, $d$ and $f$. Clustering of defaults can be linked to both of these channels, either through increased default frequencies or by high asset correlation and thus higher uncertainty of default. Before the crisis the probability of default was high, with an average of $13.47 \%$ (Panel a), and they fell slightly to $13.14 \%$ on average during the crisis (Panel c). It is after the trough that the probability of default fell considerably to a low average value of $11.23 \%$ (Panel e). We also observe that before the economic turmoil, asset correlation was on average at a low level $(0.25 \%)$. It declined even further to $0.13 \%$ during the crisis when the mass of the asset correlations moved to the left, with many obligors exhibiting virtually no correlation with each other. Those firms which withstood the crisis showed little sensitivity to economic conditions but instead a substantial reliance on the firm's characteristics. On the other 
Table 2.6

\section{Asset correlation and default rates per credit rating \& industry}

Small businesses are subject mainly to idiosyncratic risk with low asset correlation. The values reported cover the period from June 2005 to December 2010. The credit rating is constructed to represent deciles of the firms' risk distribution where 1 represents the lowest and 10 the highest credit risk. Bootstrapped S.E. in parenthesis.

\begin{tabular}{|c|c|c|c|c|c|c|c|c|c|c|c|}
\hline \multirow{3}{*}{$\begin{array}{l}\text { Indus- } \\
\text { try }\end{array}$} & \multicolumn{11}{|c|}{ Asset correlation $\rho_{i i}(\%)$ within obligor class and default rates $\bar{p}(\%)$} \\
\hline & & edit ra & & & & & & & & & \\
\hline & & 1 & 2 & 3 & 4 & 5 & 6 & 7 & 8 & 9 & 10 \\
\hline \multirow[t]{3}{*}{ Agri } & $i i$ & 0.14 & 0.00 & 0.31 & 0.00 & 0.60 & 0.70 & 0.58 & 0.47 & 0.40 & 0.38 \\
\hline & & $(0.43)$ & $(0.36)$ & $(0.50)$ & $(0.40)$ & $(0.68)$ & $(0.67)$ & $(0.72)$ & $(0.65)$ & $(0.63)$ & $0.68)$ \\
\hline & $p$ & 5.94 & 5.68 & 5.50 & 6.17 & 6.52 & 8.09 & 9.99 & 11.15 & 16.49 & 23.49 \\
\hline \multirow{3}{*}{ Mining } & $\overline{\rho_{i i}}$ & 0.00 & 3.39 & 0.08 & 0.00 & 0.43 & 0.00 & 0.00 & 0.00 & 0.00 & 2.58 \\
\hline & & (1.62) & $(5.12)$ & $(3.36)$ & (3.78) & $(4.54)$ & $(4.32)$ & (4.77) & (6.65) & (6.83) & $(9.73)$ \\
\hline & $\bar{p}$ & 9.16 & 9.05 & 8.71 & 11.96 & 13.34 & 15.03 & 18.33 & 17.21 & 23.32 & 31.57 \\
\hline \multirow[t]{3}{*}{ Constr } & $\bar{\rho}_{i i}$ & 0.30 & 0.31 & 0.23 & 0.25 & 0.41 & 0.35 & 0.38 & 0.41 & 0.61 & 0.76 \\
\hline & & $(0.30)$ & $(0.24)$ & $(0.20)$ & $(0.22)$ & $(0.23)$ & $(0.21)$ & $(0.21)$ & $(0.21)$ & $(0.23)$ & $(0.27)$ \\
\hline & $\bar{p}$ & 8.65 & 7.30 & 8.06 & 8.84 & 9.53 & 10.82 & 12.19 & 14.56 & 20.46 & 30.82 \\
\hline \multirow[t]{3}{*}{ Mfg } & $\overline{\rho_{i i}}$ & 0.34 & 0.20 & 0.29 & 0.38 & 0.21 & 0.22 & 0.45 & 0.37 & 0.50 & 0.40 \\
\hline & & $(0.30)$ & $(0.30)$ & $(0.30)$ & $(0.32)$ & $(0.27)$ & $(0.25)$ & (0.35) & $(0.28)$ & $(0.31)$ & $(0.31)$ \\
\hline & $p$ & 13.38 & 12.62 & 12.99 & 13.79 & 14.37 & 15.56 & 17.39 & 19.55 & 24.11 & 32.36 \\
\hline \multirow[t]{3}{*}{ Trans } & $\overline{\rho_{i i}}$ & 0.00 & 0.05 & 0.43 & 0.66 & 0.00 & 0.32 & 0.27 & 0.55 & 0.60 & 0.80 \\
\hline & & $(0$. & $(0$. & (0 & $(0$. & (0 & (0 & (0.47) & $(0.50)$ & $(0.57)$ & $(0.57)$ \\
\hline & $\bar{p}$ & 10.32 & 10.65 & 10.71 & 10.81 & 11.06 & 11.67 & 13.34 & 15.01 & 18.06 & 26.01 \\
\hline \multirow[t]{3}{*}{ Wholes } & $\overline{\rho_{i i}}$ & 0.19 & 0.42 & 0.05 & 0.33 & 0.41 & 0.07 & 0.42 & 0.21 & 0.51 & 0.40 \\
\hline & & $(0.24)$ & $(0.34)$ & $(0.20)$ & $(0.34)$ & $(0.35)$ & $(0.23)$ & (0.34) & $(0.27)$ & $(0.35)$ & $(0.34)$ \\
\hline & j & 13.11 & 11.89 & 12. & 13.86 & 14.10 & 14.76 & 16.49 & 18.49 & 22.90 & 30.26 \\
\hline \multirow[t]{3}{*}{ RetlTrd } & ii & 0.14 & 0.45 & 0.40 & 0.50 & 0.59 & 0.46 & 0.51 & 0.41 & 0.43 & 0.78 \\
\hline & & $(0.21)$ & $(0.30)$ & $(0.24)$ & $(0.24)$ & $(0.26)$ & $(0.22)$ & $(0.22)$ & $(0.18)$ & $(0.18)$ & $(0.26)$ \\
\hline & $\bar{p}$ & 10.67 & 9.84 & 10.50 & 11.08 & 11.14 & 12.21 & 13.10 & 14.63 & 18.21 & 25.68 \\
\hline \multirow[t]{3}{*}{ FIRE } & $\overline{\rho_{i i}}$ & 0.14 & 0.23 & 0.07 & 0.45 & 0.21 & 0.24 & 0.75 & 0.48 & 0.58 & 0.58 \\
\hline & & $(0.21)$ & $(0.26)$ & $(0.17)$ & $(0.29)$ & $(0.26)$ & $(0.28)$ & (0.41) & $(0.34)$ & $(0.42)$ & $0.43)$ \\
\hline & $\bar{p}$ & 9.25 & 8.09 & 8.94 & 9.21 & 9.46 & 10.63 & 11.63 & 14.42 & 18.40 & 25.63 \\
\hline \multirow[t]{3}{*}{ Service } & $\overline{\rho_{i i}}$ & 0.14 & 0.14 & 0.18 & 0.25 & 0.25 & 0.25 & 0.29 & 0.29 & 0.32 & 0.52 \\
\hline & & $(0.09)$ & $(0.09)$ & (0.09) & $(0.10)$ & (0.10) & (0.09) & (0.10) & $(0.10)$ & $(0.11)$ & $(0.15)$ \\
\hline & $p$ & 7.93 & 7.62 & 8.17 & 8.99 & 9.46 & 10.29 & 11.56 & 13.30 & 17.40 & 24.73 \\
\hline \multirow[t]{3}{*}{ PA } & $\overline{\rho_{i i}}$ & 0.54 & 0.00 & 0.00 & 0.33 & 0.31 & 0.35 & 1.40 & 1.44 & 0.38 & 0.94 \\
\hline & & $(0$ & $(0.8$ & ( & 1.64) & (2. & (1.95) & (2.18) & $(2.29)$ & (1.97) & $(1.61)$ \\
\hline & $p$ & 21.29 & 21.90 & 21.47 & 23.51 & 21.83 & 19.56 & 15.72 & 16.47 & 17.42 & 22.28 \\
\hline
\end{tabular}

hand, after the economic turmoil average asset correlation increased to $0.68 \%$ exposing the mutual dependence of small businesses.

Figure 2.3 sheds a different light on the evolution of portfolio default risk. It is a comparison of Monte-Carlo-generated default distributions plotted for the three separate phases defined above and for the entire period analyzed. We simulate panels of default indicators for a portfolio of 10,000 firms distributed proportionally to the historical data across credit ratings and industries. To that end we use the estimates of $\theta$ and of default thresholds $\Phi^{-1}\left(\bar{p}_{k}\right)$ which are phase-specific. The density estimates are obtained by Gaussian kernel smoothing (with interval 

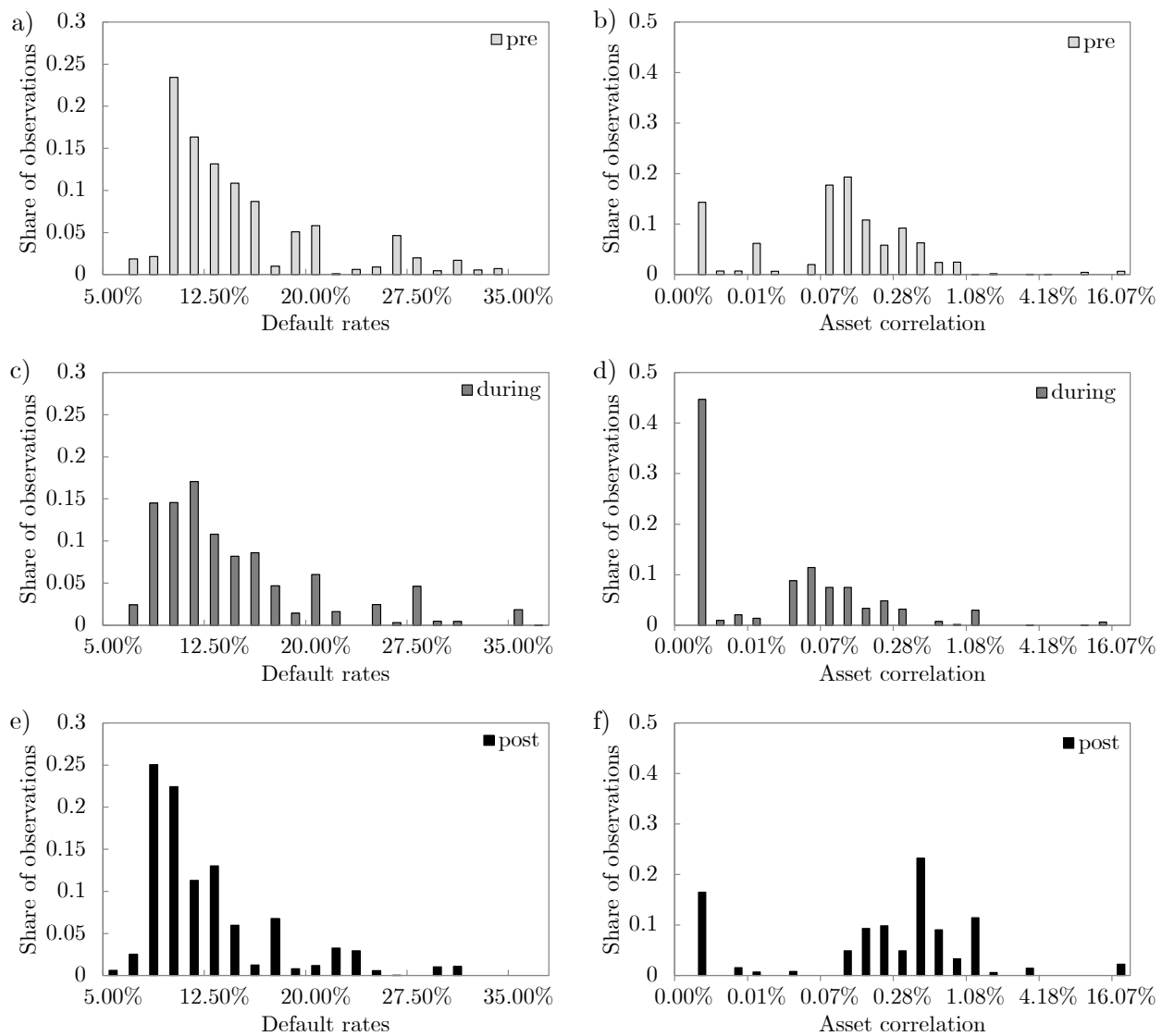

Figure 2.2: Default rates $\bar{p}$ and asset correlation $\rho_{i i}$ per credit rating \& industry in the pre-, during and post-crisis phases. The pre-crisis phase covers June 2005 till September 2007; crisis is from December 2007 until June 2009 and post-crisis phase covers September 2009 until December 2010.

length of 10). From a Basel perspective, the pricing of loan exposures and provisions should cover losses up to the expected losses. On the other hand, if there are any losses associated with the unexpected losses they should be covered by the capital requirements.

The results show that default frequency distributions were quite different during the different phases. We observe shifts in both expected and unexpected losses as we move through different phases of the crisis. The pre-crisis phase was characterized by a relatively high expected losses and moderate unexpected losses. In this phase the average realized number of defaults was 1,345 with $99.9^{\text {th }}$ percentile of losses at 1,560 defaults. Interestingly, the least uncertain level of defaults occurred during crisis. At that time the distance between the realized number of defaults $(1,314)$ and $99.9^{\text {th }}$ percentile $(1,450)$ reached its 


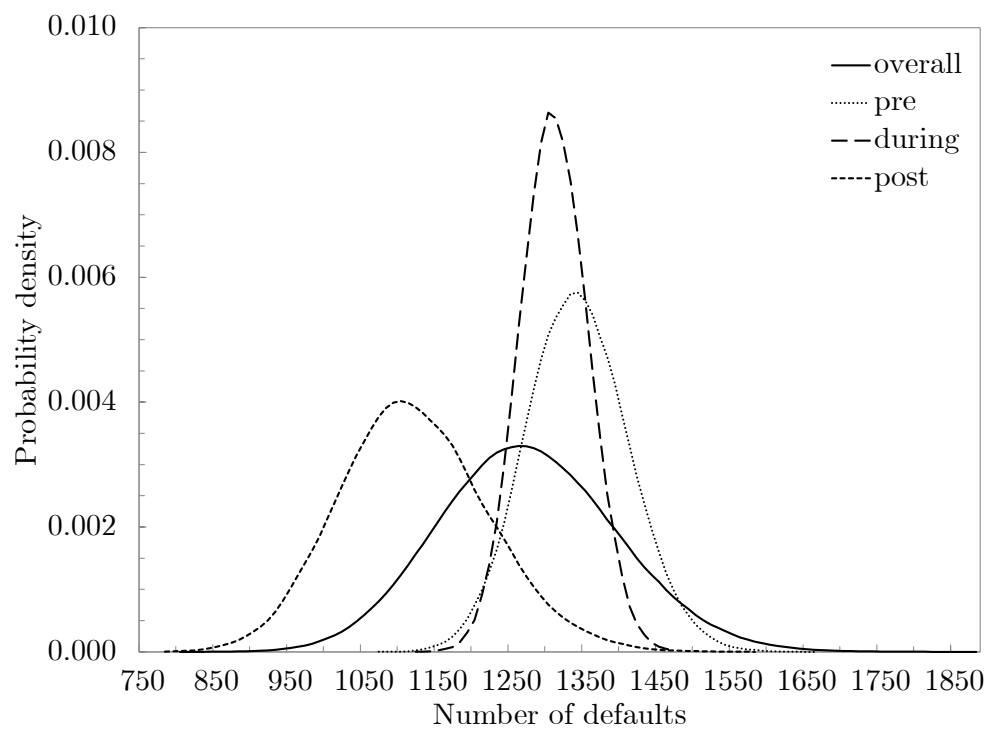

Figure 2.3: Evolution of portfolio default distribution. We observe considerable shifts in both expected and unexpected losses over the course of the crisis. Also, the default distribution narrows in the crisis. Density of number of defaults for the pre-crisis (dotted line), during the crisis (dashed line), post-crisis (square-dotted line) phases and over the whole analyzed period (solid line). The density estimates are given by Gaussian kernel smoothing (with interval length of 10) of the Monte Carlo generated default distribution. The pre-crisis phase covers June 2005 till September 2007; crisis is from December 2007 until June 2009 and post-crisis phase covers September 2009 until December 2010.

minimum, pointing to low capital requirement but nevertheless high provisions. The post-crisis phase was characterized by low expected losses (1,121 defaults), signalling an economic recovery which, however, was accompanied by high uncertainty with $99.9^{\text {th }}$ percentile at 1,453 defaults. Typically, the expected losses (thus provisions level) are considered not to embody uncertainty, which instead is associated with the unexpected losses. However, what we observe are considerable shifts in the expected losses related to levels of provision. In practice, from a risk management perspective, this should mean that the capital held by a financial institution also accounts for shifts in expected losses.

Next, we employ our estimator on a portfolio of corporate debt. We show that the suggested estimator produces results for corporate exposure that are similar to the outcomes of the Basel II regulatory framework, which illustrates its reliability. To this end we use the public information on US corporate default rates per credit rating provided by S\&P. S\&P reports payment history of about 3,000 US firms during a period of six years (from 2005 through 2010) and cover a broad range of industries. Both S\&P and our study weigh the default events by 
Table 2.7

\section{Capital requirement for corporate debt in the US}

Our estimates of capital requirement in corporate portfolios are in line with Basel II. The default rates $\bar{p}$ are an average over time of observed default frequencies. Estimation of asset correlation $\rho_{i i}$ within obligor class is based on sample of annual default rates provided by S\&P. The time span is 2005-2010. Monte Carlo S.E. in parenthesis. $K_{m}$ stands for capital requirement computed with the regulatory formula but with our estimates of asset correlation, $K_{r}$ is the regulatory one. In computation of capital requirement we assume $L G D=0.50$ and effective maturity $M=3$. Significant difference to $K_{r}$ is denoted by ${ }^{*}$ at the $90 \%$ level, ${ }^{* *}$ at the $95 \%$ level and ${ }^{* * *}$ at $99 \%$ level. Panel B displays tests for a difference between the $K_{r}$ and $K_{m}$.

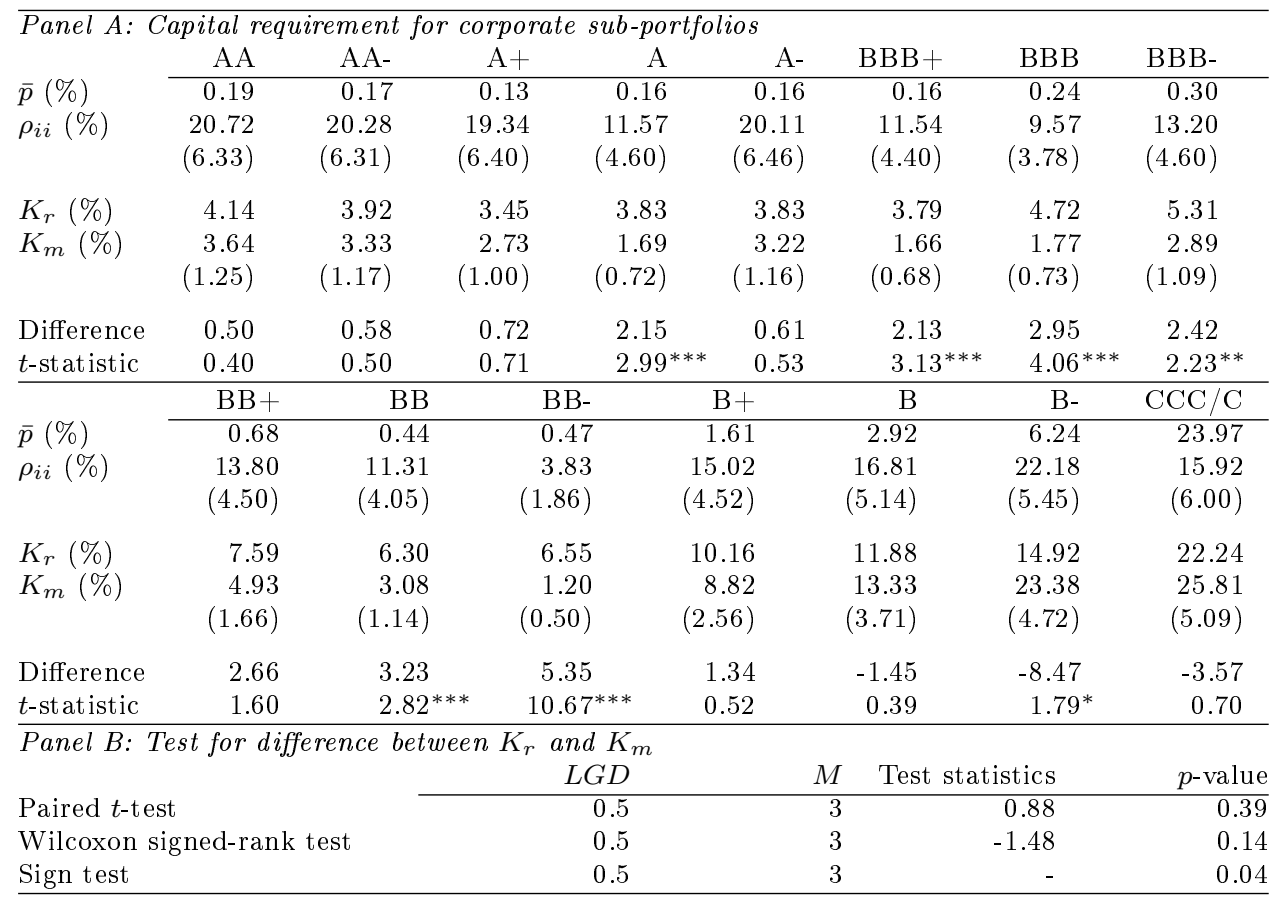

the number of obligors rather than the nominal value of default. We exclude AAA and $\mathrm{AA}+$ ratings from the analysis due to the lack of defaults in those rating categories during the period analyzed. For consistency with the Basel methodology (Gordy (2000, 2003)) the estimation of our model follows per sub-portfolio composed of obligors from one homogenous obligor class. This procedure is equivalent to estimation of a single-factor model.

Panel A in Table 2.7 shows the resulting asset correlation estimates, together with the default rates, capital requirements for corporate exposures and the difference between our model and the Basel approach. In general the results show that although larger firms have lower probabilities of default relative to retail debt, they are heavily exposed to 
changes in economic conditions. The asset correlations vary between $3.83 \%$ and $22.18 \%$ and average $15.01 \%$, which confirms a substantial interdependence in corporate exposure. Most importantly, the capital requirements for exposure by large firms (implied by our estimates of asset correlations) are in line with the regulatory ones, as shown both in Panels A and B in Table 2.7. The reported paired difference test confirms that our model and Basel II formula produce similar outcomes on average. We find no significant difference between the capital requirements computed according to regulatory formula and the ones computed using our estimates of asset correlation.

Given the consistency of Basel II and the suggested model related to portfolios of large corporates, one could perhaps expect to find matching estimates in the case of retail portfolios as well. To illustrate the implication of the model on capital requirements in financial institutions holding retail portfolios, we use the results from Table 2.6 and contrast them with outcomes of the Basel II regulatory formula. Table 2.8 suggests that small businesses are subject to inefficient capital allocations imposed by the regulator. The results show significant discrepancies in capital requirements implied by Basel II and the proposed model. For all levels of credit worthiness of the obligor, the Basel II formula significantly overstates the asset correlations (and thus the capital requirements) for sub-portfolios of small businesses. This is shown by the highly significant paired difference test. Indeed, we observe that the capital requirement is on average almost four times higher than the data would suggest. And it is the more creditworthy obligors that suffer the highest capital charges relative to their riskiness. For these firms the regulatory formula overestimates the capital requirement by as much as a factor of about ten. As a result these more creditworthy obligors pay for the credit risk of their less creditworthy peers. It also creates inverse incentives for financial institutions, which may flee to other obligor classes in which loans originated are less costly to hold. Similarly, we compute the 'aggregated' capital requirement on a portfolio level which is composed of all the obligor classes in the historical proportions. Here the regulatory capital requirement amounts to $7.31 \%$, which is almost four times more than our multi-factor model implies $(2.01 \%)$.

As the Basel Committee on Banking Supervision (2005) suggests, the overly high capital requirements for US retail loan portfolios may stem from a need for constructing a uniform framework applicable to a wider range of countries. The regulatory formula for retail asset correla- 
Table 2.8

\section{Capital requirement for small business portfolios}

Basel II significantly overstates the small business risk and introduces distortions. $K_{m}(\%)$ stands for capital requirement computed with the regulatory formula but with our estimates of asset correlation, $K_{r}(\%)$ is the regulatory requirement. We take the asset correlation as in Table 2.6 and assume $L G D=0.50$. The latter parameter does not affect the ratio $K_{r} / K_{m}$. Bootstrapped S.E. are in parentheses.

\begin{tabular}{|c|c|c|c|c|c|c|c|c|c|c|c|}
\hline athet & & & for & 60 & & $b-p c$ & (lios) & & & & \\
\hline & Cred & ting: 1 & 2 & 3 & 4 & 5 & 6 & 7 & 8 & 9 & 10 \\
\hline Agri & $\overline{K_{r}}$ & 6.01 & 5.98 & 5.96 & 6.04 & 6.09 & 6.33 & 6.71 & 6.97 & 8.21 & 9.48 \\
\hline & $K_{m}$ & 0.73 & 0.00 & 1.07 & 0.00 & 1.78 & 2.27 & 2.35 & 2.25 & 2.64 & 3.09 \\
\hline & & $(0.91)$ & $(0.80)$ & $(0.88)$ & $(0.90)$ & (1.13) & $(1.25)$ & $(1.57)$ & (1.65) & $(2.05)$ & $(2.56)$ \\
\hline & $K_{r} / K_{m}$ & 8.23 & NÁ & 5.55 & NÁ & 3.43 & 2.79 & 2.86 & 3.10 & 3.11 & 3.07 \\
\hline Mining & $\overline{K_{r}}$ & 6.54 & 6.52 & 6.45 & 7.16 & 7.49 & 7.88 & 8.59 & 8.36 & 9.46 & 10.34 \\
\hline & $K_{m}$ & 0.00 & 6.33 & 0.71 & 0.00 & 2.41 & 0.00 & 0.00 & 0.00 & 0.00 & 9.56 \\
\hline & & $(2.76)$ & $(5.77)$ & $(4.39)$ & $(5.50)$ & $(6.51)$ & $(6.57)$ & $(7.48)$ & $(8.68)$ & $(9.10)$ & (10.80) \\
\hline & $K_{r} / K_{m}$ & NÁ & 1.03 & 9.06 & NA & 3.10 & NA & NÁ & NA & NA & 1.08 \\
\hline Constr & $\overline{K_{r}}$ & 6.44 & 6.20 & 6.33 & 6.48 & 6.61 & 6.90 & 7.22 & 7.78 & 9.00 & 10.28 \\
\hline & $K_{m}$ & 1.48 & 1.34 & 1.23 & 1.36 & 1.89 & 1.88 & 2.11 & 2.46 & 3.73 & 5.00 \\
\hline & & $(0.85)$ & $(0.58)$ & $(0.59)$ & $(0.65)$ & $(0.58)$ & $(0.63)$ & $(0.64)$ & $(0.67)$ & $(0.75)$ & $(0.92)$ \\
\hline & $K_{r} / K_{m}$ & 4.35 & 4.64 & 5.16 & 4.77 & 3.51 & 3.67 & 3.42 & 3.16 & 2.41 & 2.06 \\
\hline Mfg & $K_{r}$ & 7.50 & 7.32 & 7.40 & 7.59 & 7.73 & 8.00 & 8.40 & 8.83 & 9.57 & 10.39 \\
\hline & $K_{m}$ & 2.13 & 1.53 & 1.92 & 2.29 & 1.71 & 1.84 & 2.88 & 2.79 & 3.62 & 3.63 \\
\hline & & $(1.07)$ & (1.13) & $(1.05)$ & $(1.05)$ & (1.13) & $(1.12)$ & $(1.24)$ & (1.14) & (1.21) & (1.55) \\
\hline & $K_{r} / K_{m}$ & 3.52 & 4.79 & 3.85 & 3.32 & 4.51 & 4.35 & 2.92 & 3.17 & 2.64 & 2.86 \\
\hline Trans & $\overline{K_{r}}$ & 6.78 & 6.86 & 6.87 & 6.89 & 6.95 & 7.09 & 7.49 & 7.88 & 8.54 & 9.82 \\
\hline & $K_{m}$ & 0.00 & 0.69 & 2.07 & 2.66 & 0.00 & 1.86 & 1.85 & 2.96 & 3.46 & 4.83 \\
\hline & & $(1.40)$ & (1.61) & (1.62) & $(1.52)$ & (1.35) & $(1.47)$ & $(1.52)$ & $(1.51)$ & $(1.82)$ & $(1.90)$ \\
\hline & $K_{r} / K_{m}$ & NÁ & 9.98 & 3.32 & 2.60 & NA & 3.81 & 4.05 & 2.66 & 2.46 & 2.03 \\
\hline Wholes & $\overline{K_{r}}$ & 7.43 & 7.15 & 7.35 & 7.61 & 7.67 & 7.82 & 8.21 & 8.63 & 9.40 & 10.24 \\
\hline & $K_{m}$ & 1.52 & 2.19 & 0.73 & 2.13 & 2.44 & 0.95 & 2.71 & 2.01 & 3.59 & 3.53 \\
\hline & & $(1.00)$ & $(1.00)$ & $(0.96)$ & $(1.19)$ & (1.13) & $(1.10)$ & $(1.22)$ & $(1.31)$ & (1.34) & $(1.73)$ \\
\hline & $K_{r} / K_{m}$ & 4.88 & 3.26 & 10.06 & 3.57 & 3.15 & 8.24 & 3.03 & 4.30 & 2.62 & 2.90 \\
\hline RetlTrd & $\overline{K_{r}}$ & 6.86 & 6.68 & 6.83 & 6.96 & 6.97 & 7.22 & 7.43 & 7.79 & 8.57 & 9.78 \\
\hline & $K_{m}$ & 1.15 & 2.02 & 1.97 & 2.33 & 2.56 & 2.35 & 2.61 & 2.47 & 2.91 & 4.73 \\
\hline & & $(0.84)$ & $(0.77)$ & $(0.67)$ & $(0.61)$ & $(0.62)$ & $(0.64)$ & $(0.63)$ & $(0.59)$ & $(0.63)$ & $(0.82)$ \\
\hline & $K_{r} / K_{m}$ & 5.95 & 3.31 & 3.47 & 2.99 & 2.73 & 3.07 & 2.85 & 3.16 & 2.95 & 2.07 \\
\hline FIRE & $\overline{K_{r}}$ & 6.56 & 6.33 & 6.49 & 6.55 & 6.60 & 6.85 & 7.08 & 7.74 & 8.61 & 9.77 \\
\hline & $K_{m}$ & 1.03 & 1.20 & 0.69 & 1.93 & 1.31 & 1.52 & 3.01 & 2.67 & 3.43 & 4.02 \\
\hline & & $(0.78)$ & $(0.75)$ & $(0.70)$ & $(0.70)$ & $(0.83)$ & $(0.90)$ & $(0.94)$ & $(1.06)$ & (1.39) & (1.67) \\
\hline & $K_{r} / K_{m}$ & 6.35 & 5.26 & 9.45 & 3.39 & 5.04 & 4.51 & 2.36 & 2.90 & 2.51 & 2.43 \\
\hline Service & $\overline{K_{r}}$ & 6.31 & 6.25 & 6.35 & 6.50 & 6.60 & 6.78 & 7.07 & 7.48 & 8.40 & 9.66 \\
\hline & $K_{m}$ & 0.90 & 0.87 & 1.06 & 1.38 & 1.42 & 1.49 & 1.78 & 1.94 & 2.42 & 3.75 \\
\hline & & $(0.32)$ & $(0.30)$ & $(0.28)$ & $(0.30)$ & $(0.31)$ & $(0.31)$ & $(0.32)$ & $(0.36)$ & $(0.43)$ & $(0.55)$ \\
\hline & $K_{r} / K_{m}$ & 7.00 & 7.15 & 6.00 & 4.71 & 4.65 & 4.53 & 3.98 & 3.85 & 3.47 & 2.57 \\
\hline PA & $\overline{K_{r}}$ & 9.14 & 9.24 & 9.17 & 9.49 & 9.23 & 8.83 & 8.04 & 8.20 & 8.41 & 9.30 \\
\hline & $K_{m}$ & 3.56 & 0.00 & 0.00 & 2.89 & 2.68 & 2.71 & 5.11 & 5.33 & 2.65 & 4.90 \\
\hline & & $(2.45)$ & $(2.93)$ & $(3.46)$ & $(4.32)$ & $(4.72)$ & $(4.51)$ & $(4.15)$ & $(4.39)$ & $(4.25)$ & $(4.08)$ \\
\hline & $K_{r} / K_{m}$ & 2.56 & NÁ & NÁ & 3.28 & 3.44 & 3.26 & 1.57 & 1.54 & 3.17 & 1.90 \\
\hline & Test $f$ & ore & 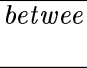 & 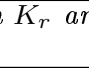 & $\begin{array}{l}d K_{m} \\
L G D\end{array}$ & & est $s$ & istics & & & value \\
\hline Paired $t$ & -test & & & & 0.5 & & & 41.65 & & & 0.00 \\
\hline $\begin{array}{l}\text { Wilcoxo } \\
\text { test }\end{array}$ & n signed & & & & 0.5 & & & -8.68 & & & 0.00 \\
\hline Sign tes & & & & & 0.5 & & & -9.90 & & & 0.00 \\
\hline
\end{tabular}


tion does not match historical loan data. Instead the Basel Committee on Banking Supervision reverse-engineered asset correlation from the information on capital held historically by banks. Our results suggest that the retail asset correlation function obtained and imposed by regulator is far from accurate. Moreover, the resulting inefficiencies in capital allocations encourage more financing in the large corporate sector rather than in the small business economy. This is an undesirable outcome, particularly from the point of view of policy makers.

From a risk management perspective an important feature of the approach suggested in this study is given by a possibility to assess the parameter uncertainty of capital requirements. For example, if we take the prudential value of the capital requirement equal to its estimate plus its uncertainty (this is the standard error), the capital requirement increases by $10.80 \%$ (from $9.56 \%$ to $20.36 \%$ ) for least creditworthy obligors from the mining industry. But on average the prudential financial business would hold $1.87 \%$ above the model's requirement.

This leads us to another aspect of parameter uncertainty, namely uncertainty which stems from normality assumptions of common risk factors. Although the normality of risk factors is not a necessity for the construction of the multi-factor model, we derive our estimates for asset correlation for the case in which the common and idiosyncratic risk factors are distributed normally. We conducted simulations to explore the effects of implementing student-t and gamma distributed risk factors. The estimates remain close to the values under normality. In spite of this, any difference in the distribution of the risk factors may have an impact on the portfolio risk, see Schönbucher (2000). Thus if a financial institution believes the common risk factors of its portfolio follow a fat-tailed distribution, the proper response is to implement a corresponding prudential approach to asset correlation estimates and following capital requirements.

\subsection{Concluding remarks}

This paper compares the minimum capital requirements implied by the Basel II Accord and those implied by a multi-factor firm value model for an extensive data set of US small businesses. We find, firstly, that for retail loan portfolios, the Basel II formula overestimates the need for economic capital. Moreover, it is the most creditworthy small obligors that suffer the highest capital charges relative to their riskiness. These 
most creditworthy obligors essentially pay for their riskier peers. This can result in distorted lending and risk management practices by financial institutions which hold retail loan portfolios. Our empirical results show that, from a credit risk perspective, retail exposures are a much safer investment than the regulations would suggest. In our view this regulatory flaw results from the overly-simplistic way in which Basel II models and estimates the asset correlations in retail loan portfolios.

Secondly, we trace the evolution of two important elements of default risk in a portfolio of loans: expected and unexpected losses. Interestingly, the crisis eliminated many uncertainties about default in a retail loan portfolio. Thus, the firms which withstood the deterioration of macroeconomic conditions did not go systematically into default.

Lastly, equipped with a simple yet effective estimation technique, we provide an empirical analysis of a representative panel of exposures to US small businesses between 2005 and 2011. We find that, in general, sensitivity to the common risk factors remains low and small business risk results predominantly from idiosyncratic risk, even when controlling for different definitions of the default event, geographical proximity, as well as industry and firm size heterogeneity. Our results show that only $0.00-3.39 \%$ of the asset variability is explained by economy-wide risk factors. The remaining $96.61 \%-100.00 \%$ of small business risk is due to changes in the firm-specific characteristics. Importantly, regardless of small businesses' riskiness, industry or firm size, our estimates of asset correlations are significantly lower than any available estimates for corporate firms. 


\section{Chapter 3}

\section{Ripple effects from industry defaults}

\subsection{Introduction}

In 2008 the Big Three: General Motors, Chrysler and Ford found themselves on the brink of financial insolvency and had to seek financial support from the government. In a highly leveraged and concentrated automotive industry this caused financial distress to spread to their suppliers. Just by the end of 2008 GM held back $\$ 10$ billion in payments to suppliers of parts which had already been delivered (Vlasic and Wayne (2008)). The resulting liquidity shortage meant many suppliers were unable to meet obligations to subcontractors, so further weakening the industry's supply chain (Klein (2009)). This is an example of how major corporate credit event (which we call industry default) generates negative externalities and wealth effects. This can affect the creditworthiness of firms in the supply chain and so can trigger default clustering. This can result in an industry-wide change in default rates ${ }^{1}$. Throughout this paper we will use the term ripple effect to describe such a change in the industry default rate following industry-wide default. The main question we ask is whether an industry default is followed by default clustering (ripple effect) in linked industries. By 'linked industries' we mean the industries that are linked via supply chain (through customer-supplier relationships as in Cohen and Frazzini (2008)) or via

\footnotetext{
${ }^{1}$ Industry default rate measures the rate at which active and financially sound small businesses default within one year. The default event takes place if a payment is either 90 days overdue or is unlikely to be paid.
} 
the product market (competitors as in Lang and Stulz (1992)).

Our contribution to the existing literature is threefold. First, we derive our results for U.S. small businesses in manufacturing industries for which the empirical evidence for default risk spillovers is scarce. Importantly, private firms are not less susceptible to counterparty risk and liquidity shocks than more researched large corporates. But, in general, the measurement of default risk spillover relies on information about individual counterparty exposure and bilateral links. Collecting this data for small business lending is hindered by both the prohibitive cost and less rigorous information quality. This information scarcity can subject even a diversified investment portfolio to the potential for volatility and future losses. This paper offers a plausible alternative for modelling counterparty exposure on an aggregate level using production process linkages. This suggested alternative uses only publicly available data, which could make it useful in bank risk management departments.

As a ripple effect can significantly increase losses on a loan portfolio, its measurement is of special interest to providers of small business finance. According to the FDIC, US commercial banks' exposure to loans granted to small businesses is significant and amounted in June 2011 to $24.9 \%$ of all commercial and industrial loans. This study aims to provide insights into default risk transmission to small businesses using a new data set. This data spans 2005 to 2011 and combines information on major defaults on S\&P rated debt with a panel of small businesses defaults, industry production process linkages, and industry characteristics.

Second, the study also provides an original perspective on aspects of portfolio concentration and default risk transmission. In particular, we take the point of view of small business finance providers, many of which face potential risk from the ripple effect on their concentrated loan portfolios. We examine how the magnitude of ripple effects changes with different portfolio concentrations in large, interconnected and highly concentrated industries. Industry size refers to the number of establishments operating in a given industry, interconnectedness corresponds to the number of bilateral connections between industries, and concentration measures the degree of competition between firms and their ability to set prices above marginal cost.

Lastly, we provide novel evidence on Kiyotaki and Moore (2002) balance sheet contagion. We analyze here a ripple effect mechanism in which industry default propagates either directly through the flow of receivables that link firms along the production process, or indirectly 
through fluctuations in asset prices. It is important to recognize that this transmission occurs more frequently and and begins well in advance of bankruptcy. So far research on default risk transmission focuses on the role of bankruptcy as the event causes default risk in linked industries. But bankruptcies are relatively rare events, they are often anticipated and are often preceded by defaults, late payments, debt renegotiation and fire sales. A bankruptcy event is therefore a very late indicator of default risk spillover. Instead, default risk can spread months prior to a bankruptcy and is often set in motion by events such as first payment disruption to suppliers. For example, in 2010, out of 50 defaults on $\mathrm{S} \& \mathrm{P}$ rated debt in the U.S. only 15 were caused by bankruptcy events (Chapter 11 filings). To this end, in the spirit of Kiyotaki and Moore (2002) we would like to verify the existence of such early default risk spillover effects or ripple effects for linked industries.

We present evidence that distress in one industry has a ripple effect on linked industries. Our results show that the default rate among small businesses is higher when there is industry default in any industry which buys their products, as well as in the same industry as them. We find that small businesses in larger industries (measured by the number of establishments) are subject to lower ripple effect. It means that sizable industries suffer lower ripple effect because the damage to an industry's credit worthiness is measured relative to the number of establishments in that industry. Furthermore, the relationship between concentration (industry's markup) and the ripple effect is negative. More concentration offers the possibility to benefit from a distress of another company.

Default clustering can seem, to an outside observer, to result from common shocks causing otherwise heterogeneous firms to suffer simultaneous financial distress. ${ }^{2}$ Additionally, once initiated, this aggregate behavior persists in the economy and ripples through several industry sectors. Abstracting from aggregated shocks, as noticed in Hor-

\footnotetext{
${ }^{2}$ In credit risk modelling such common shocks can be found i.e. in factor models or intensity models. In particular, the asymptotic single factor model in Basel II identifies one common risk factor as a driver of many defaults throughout the whole economy. Also some intensity models subject firm's default intensity to a change in macroeconomic risk factors. Alternative methods of default clustering in the literature include, for example, jumps in intensity models (Berndt, Ritchken, and Sun (2010)), Markov chains in which default intensities change at the default of a counterparty (Kraft and Steffensen (2007)) or frailty models in which default clustering is partially explained by an unobserved latent variable driving default (Duffie, Eckner, Horel, and Saita (2009)).
} 
vath (2000), an alternative mechanism to explain firms' behavior might comes directly from the production process. Many commodities are intermediate inputs for a new commodity. We use the production process setting in Figure 3.1 to illustrate the ripple effect. We talk about customer or supplier ripple which takes place between two industries linked by a production process.

For example, consider industry $j$ which uses the intermediate output of industry $i$ in its own production process of another commodity. ${ }^{3}$ In this case, firms from industry $j$ enter a supplier-customer relationship with firms from industry $i$ which is accompanied by credit chains as in Kiyotaki and Moore $(2002,1997)$. Suppose an industry default occurs in industry $j$ at time $t$. Although the involved customers and suppliers are not directly identified, the existence of the linkage along the production process between industries $j$ and $i$ indicates that at least some firms from $i$ enter a direct customer-supplier relationship, thus being potentially exposed to distress of their counterparties in $j$. For these firms in our example, the default of firms in $j$ translates into a shock affecting their receivables, resulting in decreased value for the firm. Consequently, the ripple results in an increase in the number of defaults in industry $i$.

We talk about a competitor ripple which occurs within the same industry. In this case an industry default can have either a negative or positive effect on industry competitors. First the adverse effect, called contagion effect, arises from negative information about industry profit perspectives. Suppose that a firm's investments are correlated with the investments of its competitors. If an industry default occurs due to an adverse shock to competitors' investments it also signals a decrease in the firm's investment value. Second the positive effect, called competitive effect, reflects an opportunity to seize new market share that is lost by the distressed competitors, and in consequence to gain market power and to benefit from some form of monopoly (Lang and Stulz (1992)).

\footnotetext{
${ }^{3}$ Two industries are linked by a production process if one supplies intermediate goods to the production of the other. Most of intermediate goods are a result of production to order. Abramovitz (1948) distinguishes also two other types of production: spot production (i.e. services) and production to inventory (consumer durables).
} 


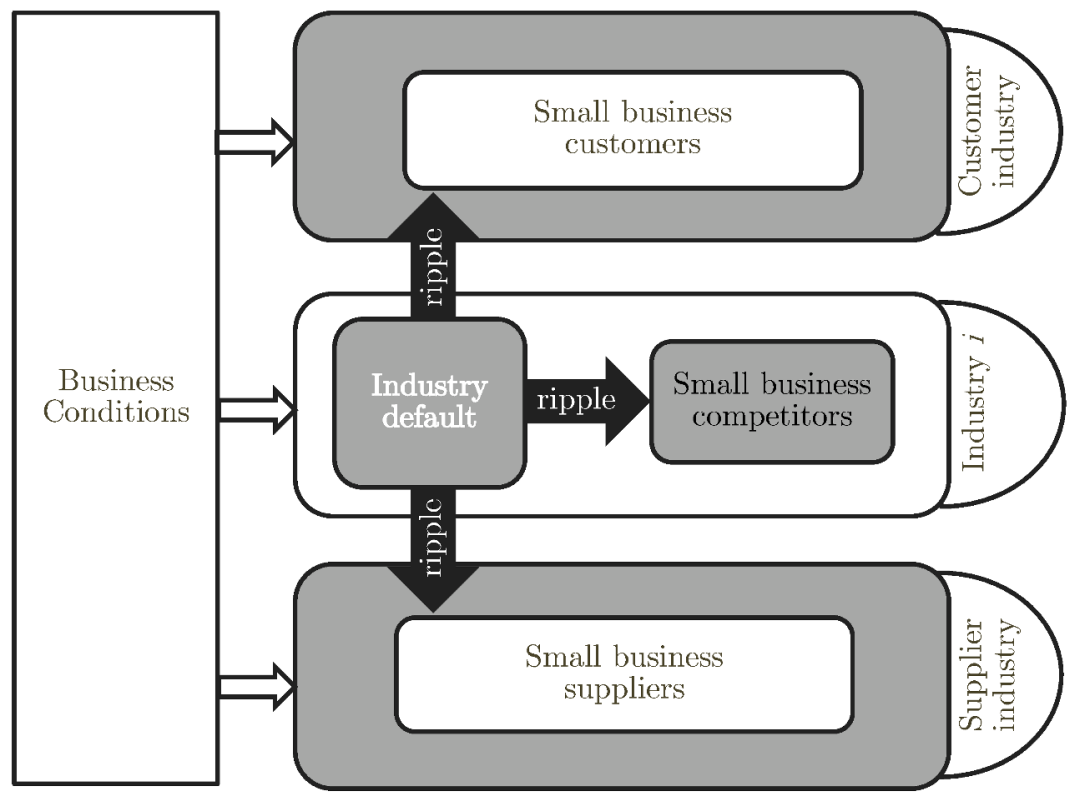

Figure 3.1: Customer, supplier and competitor ripple effects from an industry default. Industry $i$ awaits intermediate inputs from supplier industry and owes the customer industry to complete products but suffers an industry default.

\subsection{Example}

In this paper we relate the network of product flows to how default risk progresses in the economy. We take an example of an industry default and observe whether it is followed by default in vertically linked industries. Figure 3.2 illustrates such development in a subset of the automotive supplier network. Indeed industry defaults follow a pattern in this case. The product flow is a perfect indicator of the sequence in which industries are affected by an industry default. Starting with the top customer industry (motor vehicle parts) which defaults in the first quarter of 2008 for the first time in a year, the industry defaults occur next in this industry's direct suppliers. Next in line are fabricated metal products industry, which delivers a considerable $7 \%$ of its production to motor vehicle parts makers. With time, the default risk also ripples further to more distant suppliers.

A similar picture appears in U.S. small businesses operating in those industries. Figure 3.3 illustrates the time series behavior of the private firms operating in the automotive supplier network. To draw the picture in Panel (a) we use all industries for which customers are shown 


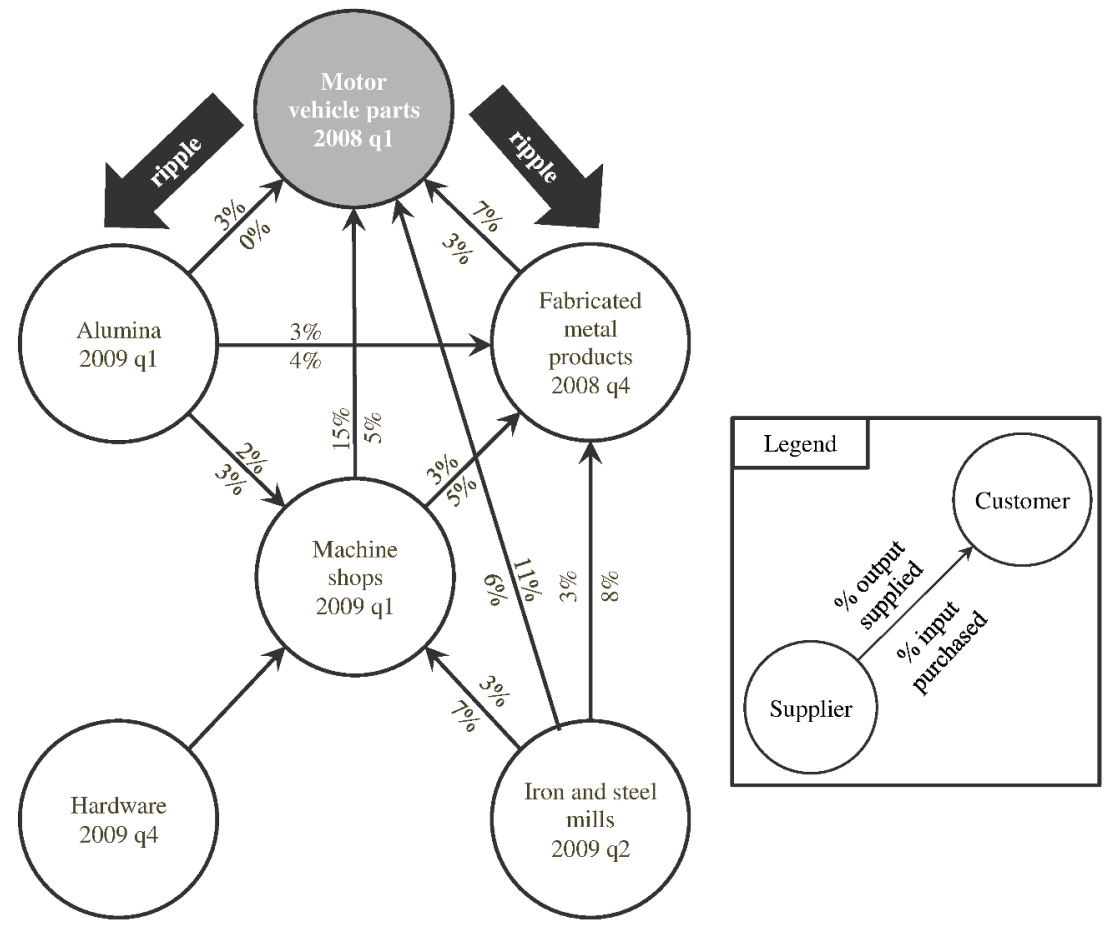

Figure 3.2: Subset of the automotive supplier network and industry default. The figure presents a supplier network given by the U.S. Bureau of Labor Statistics Input Output tables. The arrows indicate product flows. The quarters in the circles denote quarters in which first industry default occurred as of $2007 \mathrm{q} 1$.

in Figure 3.2. In the next step, we compute the small business default rates and set the time studied around the time of distress in the customer's industry. We benchmark their behavior against a sample of matched industries which resemble them in all aspects other than the industry default rates in customer industries (the matching procedure is described in detail in section 3.6.1). The general response of small businesses' default rates to industry default in a customer industry is an increase next quarter. Similarly, Panel (b) shows ripple effects for small businesses in industries that buy form the ones in Figure 3.2 and Panel (c) shows ripple effect for small businesses in the same industries as those in Figure 3.2. In case of a supplier being in default, the small business default rates are always higher than for the matched sample. Also, they show an increased default risk (relative to the matched sample) one quarter after the industry default in the supplying industry. 
(a)

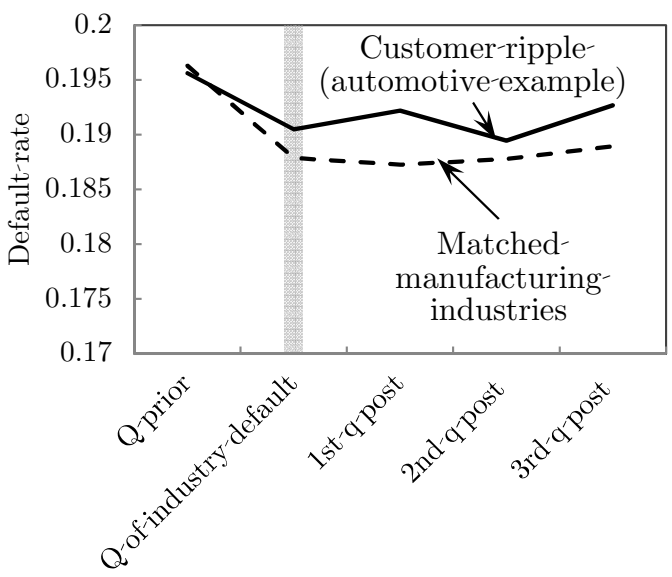

(b)

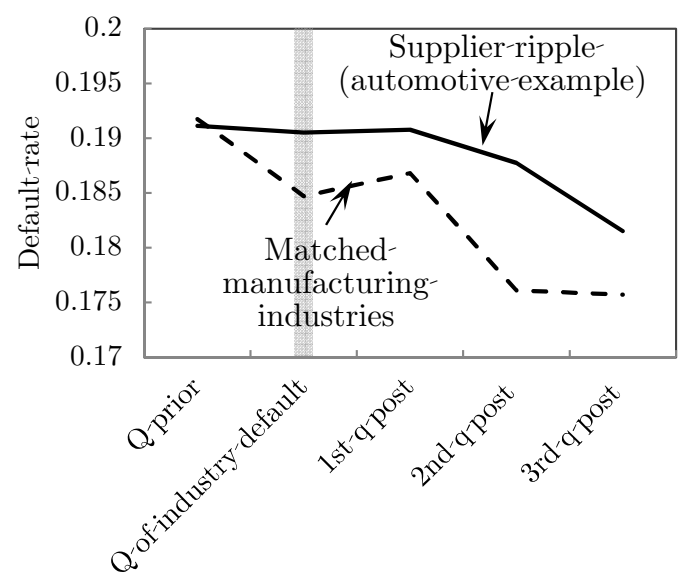

(c) -

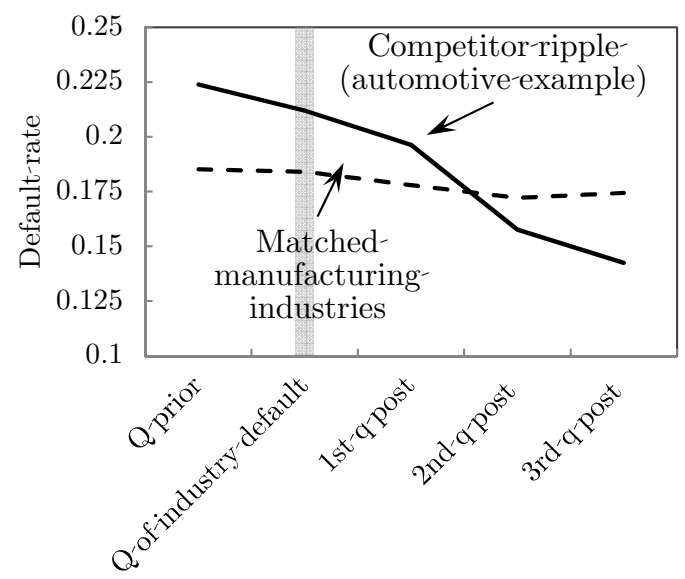

Figure 3.3: Default rates among small firms in the automotive supplier network. The figure presents default rates in U.S. small firms in the industries related to automotive industries around industry defaults displayed in Figure 3.3. 


\subsection{Related literature}

In an economy with simultaneous borrowing and lending between firms, a default on one loan can significantly affect the riskiness of another. Performance of such interlocked loans moves in-step with the business cycle, and in turbulent times leads to default clustering. Kiyotaki and Moore (2002) discuss a theoretical framework in which local defaults spread to other sectors in the economy via accounts receivables or similar assets used as collateral. The accounts receivable mechanism is the subject of numerous studies regarding the role of supply chain and credit networks in the transmission of shocks. For example Raddatz (2010) or Holly and Petrella (2012) presents evidence that a customersupplier network propagates sectoral or aggregate shocks through the economy. Yet only Wagner, Bode, and Koziol (2011) recognize the importance of market structure in default risk transmission. In their paper a distress of one supplier benefits its competitors as they gain more market power. The collateral mechanism is studied by Acharya, Bharath, and Srinivasan (2007), Benmelech and Bergman (2011) and Kiyotaki and Moore (1997). At the heart of this second mechanism rests a devaluation of an asset class which if pledged as collateral worsens the ability of a credit-constrained firm to raise more funding and decreases its net worth. As Bernanke and Gertler (1989) point out, such unrelated shocks to a borrower's collateral value and thus its net worth can generate fluctuations in an aggregate economy.

On a portfolio level, both mechanisms of ripple effects can work simultaneously and manifest themselves as default clustering. Empirically, it is their net effect that is observed. Without any knowledge of collateral prices and re-deployability, the ripple effect from counterparty risk is virtually indistinguishable from the ripple effect from collateral deterioration. In this paper we study the net effect of these two.

Our study is motivated by the literature which examines the role of market structure in the ripple effect seen among competing firms in the same industry. An important work by Lang and Stulz (1992) provides empirical evidence for a generally adverse stock price reaction in response to the announcement of a competitor's bankruptcy. This pattern, however, is reversed for firms in highly concentrated industries with lose credit-constraints. Similar results are shown in Cheng and McDonald (1996) and Hertzel et al. (2008). The latter finds significant negative effects which extend beyond the single industry, also 
affecting supplier and customer industries. In addition, a more recent study by Jorion and Zhang (2009) explores the default risk implications for the counterparties of a firm undergoing bankruptcy. When studying creditors of the distressed firm they find strong evidence of an increase in CDS spreads and greater probability of failure in the near future. Hertzel and Officer (2012) discuss changes in loan conditions under which firms obtain their funding at the time of bankruptcy announcements by industry competitors. However the existing studies focused on the ripple effect of bankruptcies (which in general are events that happen late in the process) to capture the balance sheet contagion as described by Kiyotaki and Moore (2002). Also, the aspects of size and production linkages of an industry were missing from the market structure analysis, although they are receiving considerable attention in the banking industry.

Thus, although an industry default is an important credit event, to date there is no evidence about whether or how this has an impact on default rates in small business loan portfolios. Instead, the existing evidence of default risk transmission is limited to outcomes of bankruptcies, and this data is only available for large public firms. But as Kiyotaki and Moore (1997) notice, the effect of default risk transmission is amplified in an economy with small firms with limited access to capital markets, thus making them more credit-constrained. In such an economy, the entrepreneur finds herself borrowing from and lending to her suppliers even though she could be credit-constrained herself.

\subsection{Empirical methodology}

We test the existence of the ripple effect in manufacturing industries using difference-in-difference methodology. To this end, we estimate variants of the following specifications on industry-quarter observations, which include 77 manufacturing industries in 22 quarters. The dependent variable is small business default rate which measures the rate at which financially sound, non-defaulted small businesses go into default withing one year:

$$
\begin{aligned}
p_{i, t} & =\alpha_{C u} \text { Dose }_{C u, i, t} \times \text { Post }_{C u, i, t}+\alpha_{S u} \text { Dose }_{S u, i, t} \times \text { Post }_{S u, i, t}+ \\
& +\alpha_{C o} \text { Dose }_{C o, i, t} \times \text { Post }_{C o, i, t} \\
& +\beta X_{i, t}+\sum_{i=1}^{I} \text { Industry }_{i}+\sum_{t=1}^{T} Q_{t}+\epsilon_{i, t}
\end{aligned}
$$




$$
\text { where } \text { Dose }_{n, i, t}=\frac{\sum_{j=1}^{I} \text { Debt }_{n, j i, t}}{\sum_{j=1}^{I} \text { Assets }_{n, j i, t}}
$$

Subscripts $i$ and $t$ denote industry and quarter respectively. The subscript $n$ corresponds to the treatment type: $C u$ denotes customer ripple, $S u$ supplier ripple and $C o$ competitor ripple. The variable Dose measures the treatment's intensity. In particular, Dose $C u, i, t$ is the total amount of debt in default on $\mathrm{S} \& \mathrm{P}$ rated debt in all industries $j$ buying from industry $i$ at time $t$, divided by the total assets in industries those industries. In other words, it is the amount in default in customer industries standardized by the overall size of customer industries. Similarly, Dose $_{S u, i, t}$ is the amount in default in supplier industries standardized by the overall size of those industries. Dose ${ }_{C o, i, t}$ denotes the amount in default in the same industry standardized by its own size. Post $_{C u}$, Post $_{S u}$ and Post $C o$ are dummies that take the value of one in the quarter following an default, respectively, in the industries of the customer, supplier or the same industry. Matrix $X$ stands for industry level controls. We also include industry and quarter fixed effects. The industry fixed effects subtract any unobserved heterogeneity on the industry level. This way we control for any time invariant factors, i.e. infrastructure, supply chain base, etc. In this case the identification of ripple effects comes from the time series variation in small business default rates on an industry level. Also, the quarter fixed effects account for any aggregate co-movement in the small business default rate. The variable Dose is absorbed by the industry fixed effects as its potential level equals the leverage ratio in customer industries. The variable Post is absorbed by the quarter fixed effects.

We expect the interaction terms between Dose and Post to be associated positively and significantly with the small business default rate. This relationship is expected to be positive because the small business default rate should be higher following distress in a linked industry (Post variable equal one). Also, the more severe is the distress in the linked industry (high level of Dose), the higher the small business default rate.

To illustrate the difference-in-difference approach, consider the following example. Suppose we are interested in the effect of a default by GM in the first quarter of 2009 on the default rate of small businesses in the 'Engine, turbine, and power transmission equipment manufacturing' industry. This industry supplies the 'Motor vehicle manufacturing' industry in which GM operates. To this end, we would subtract the 
default rate after the GM default from the default rate prior to the first quarter of 2009. However, the 2009 GM default overlapped with the onset of recession, a factor which could also affect the small business default rate in the 'Engine, turbine, and power transmission equipment manufacturing' industry. Therefore, benchmarking the outcome against a 'control' industry, i.e. 'Metalworking machinery manufacturing', that was not affected by any customer ripple at that time helps to control for general business conditions. In essence, the differencein-difference approach compares the difference in default rate in the 'Engine, turbine, and power transmission equipment manufacturing' industry pre and post GM default to the difference in 'Metalworking machinery manufacturing' industry pre and post GM default (see also Bertrand and Mullainathan (2003) for other examples of difference-indifference approach). Our regression differs from the above example because we allow more severe industry defaults to be followed by even higher increases in small business default rate.

Since the industry defaults were staggered over time, the regression in (3.1) will set as 'control' the industries that, at a given time, are not treated by the specific ripple type. The control industries, however, may include industries that were (or will be) under ripple effect. In fact all manufacturing industries face a ripple effect at some time. Also, if we are interested in the customer ripple, the control industries can also face supplier or competitor ripple. Similar logic applies to supplier and competitor ripple.

To determine the role of industry characteristics in the ripple effect, we estimate the following regression:

$$
\begin{aligned}
p_{i, t} & =\sum_{n=C u, S u, C o} \gamma_{n} \text { Dose }_{n, i, t} \times \text { Post }_{n, i, t} \times \text { Feature }_{i, t} \\
& +\sum_{n=C u, S u, C o} \alpha_{n} \text { Dose }_{n, i, t} \times \text { Post }_{n, i, t} \\
& +\sum_{n=C u, S u, C o} \theta_{n} \text { Post }_{n, i, t} \times \text { Feature }_{i, t} \\
& +\beta X_{i, t}+\sum_{i=1}^{I} \text { Industry }_{i}+\sum_{t=1}^{T} Q_{t}+\epsilon_{i, t}
\end{aligned}
$$

where the Feature stands for an industry characteristic of interest, i.e. size (which is the number of establishments in an industry), interconnectedness (which is the number of overall connections to suppliers and customers) and concentration (which is the industry markup). The subscript $n$ corresponds to the treatment type: $C u$ denotes customer 
ripple, $S u$ supplier ripple and $C o$ competitor ripple. An industry which is smaller, less interconnected and less concentrated is expected to suffer higher ripple effects. The interaction term Dose $\times$ Feature is absorbed by the Feature variable.

\subsection{Data}

The data is on quarterly frequency with information available on industry level. We are interested in measuring the ripple effect for U.S. small businesses in 77 manufacturing industries in 22 quarters from 2005 q3 to $2010 \mathrm{q} 4$. This amounts to a total of 1,694 observations.

\subsubsection{Dependent variable}

We adopt the Basel Accords view to compute the small business default rate. It means that a default event takes place if a payment occurs either 90 days overdue or is unlikely to be paid (i.e. due to bankruptcy or a credit rating downgrade to default). Here, the small business default rate is a cumulative number and represents a share of financially sound firms that go into default at any time within 1 year. In particular, at time $t$ we identify a group of firms in non-defaulted state. We track them over the next four quarters to see if they go into default at any point in time. Then, the default rate is the sum of those defaults over the initial number of firms. We repeat this procedure for each quarter.

To that end, we conduct an extensive analysis of nearly 240,000 U.S. small businesses per quarter from a new data set provided by Dun $\&$ Bradstreet. The data set covers rich quarterly information on firms' actual borrowing and payment behavior, i.e. number and amount of late payments. In addition each record contains information on credit ratings, County Court Judgments, legal pre-failure events, legal form, age, industry or location. The data set spans the period from 2005 q2 to $2011 \mathrm{q}^{4}$ during which the study looks a representative blend of U.S. industries, regions and firm sizes (for more detail on small businesses sample please refer to Bams, Pisa, and Wolff (2012)). The D\&B data on small business payment behavior is collected from about 6,000

\footnotetext{
${ }^{4}$ Sample is limited by the data provided by Dun \& Bradstreet. As the computation of the small business default rate requires forward looking information on four quarters ahead, we are able to compute small business default rate only up to 2010 q4.
} 
Table 3.1

\section{Summary statistics}

The sample runs from 2005 q 3 to 2010 q4 and includes 340 major defaults on S\&P rated debt with complete information on industry association. Some of the major defaults in one industry fall in the same quarter, so there are 255 unique industry defaults. The table reports the total amount on which industry default occurred and describes manufacturing industries in the U.S. The industry's interconnectedness is measured by the total number of input-output relationships, as derived from U.S. Bureau of Labor Statistics IO data. The input-output relationships are only those in which either CUST or SUPP have value greater than $1 \%$.

\begin{tabular}{lrrrrr}
\hline & N & \multicolumn{1}{c}{ Mean } & \multicolumn{1}{c}{ SD } & Min & \multicolumn{1}{c}{ Max } \\
\hline Panel A: Manufacturing industries characteristics & & & & \\
Coverage of the small businesses & 1,694 & 1407.836 & 3617.539 & 10 & $37,650.00$ \\
Default rate of small businesses (\%) & 1,694 & 17.991 & 5.103 & 0 & 40 \\
Dose customer x Post (\%) & 1,694 & 0.983 & 7.576 & 0 & 173.905 \\
Dose supplier x Post (\%) & 1,694 & 1.923 & 17.465 & 0 & 391.792 \\
Dose competitor x Post (\%) & 1,694 & 0.284 & 4.424 & 0 & 173.905 \\
Major default within 1 Y & 1,694 & 0.143 & 0.351 & 0 & 1 \\
Share large firms (\%) & 1,694 & 4.425 & 3.745 & 0 & 31.818 \\
Share young firms (\%) & 1,694 & 0.982 & 1.653 & 0 & 13.158 \\
Median credit score & 1,694 & 486.419 & 14.060 & 461 & 560 \\
Single customer industry & 1,694 & 0.065 & 0.246 & 0 & 1 \\
Single supplying industry & 1,694 & 0.078 & 0.268 & 0 & 1 \\
Sales [mil] & 1,694 & 64.800 & 79.700 & 2.892 & 773 \\
Inventories [mil] & 1,694 & 6.463 & 6.853 & 0.310 & 51 \\
Industry size & 1,694 & $4,156.370$ & $5,512.680$ & 101 & 34,385 \\
Industry interconnectedness & 1,694 & 30.679 & 7.267 & 8 & 46 \\
Industry concentration & 1,694 & 0.338 & 0.103 & 0.109 & 0.843 \\
\hline Panel B: Major defaults & & & & & \\
Debt amount [mil \$] per major default & 340 & $2,630.810$ & $10,438.960$ & 0 & $144,426.200$ \\
\hline
\end{tabular}

major firms (both financial and non-financial). Table I Panel A summarizes the final sample of U.S. manufacturing small businesses which are exposed to ripple effects from industry defaults. It shows that the number of small businesses per industry ranges from 10 to 37,650 .

\subsubsection{Independent variables}

The independent variables of interest are Dose and Post. There are three types of treatment, thus there are three variants of Dose and Post variables. An industry can be affected by customer $(C u)$, supplier $(S u)$ or competitor $(C o)$ ripple. The first variable of interest, Dose, measures the severity of the three effect treatments. In particular, Dose $\mathrm{Cu}_{i, t}$ denotes the defaulted debt in customer industries, standardized by the total assets of industries in which the industry default occurred; Dose $_{S u, i, t}$ denotes the intensity of industry default in supplier industries; and $D_{o s e_{C o, i, t}}$ denotes the intensity of industry default in the firm's own industry. We standardize using firm's total assets in the Compustat sample that operates in that industry. 
The Dose of this treatment is derived from information on major defaults on S\&P rated debt. We focus on major defaults since they have a greater ability to stimulate an industry-wide response (see also Lang and Stulz (1992)). There are at least two reasons to assume this. First, damage to existing production relationships increases with size of the default. As a result, a larger number of suppliers are affected and suffer a more extensive shock to their accounts receivables. Second, a major default can reveal negative information about industry competitors if their investments are correlated with the investments of the defaulting firm. This would indicate that the industry is in imminent distress. Consequently, uninformed customers reduce their demand for intermediate goods and thus alter an industry's creditworthiness.

Data about major U.S. industry defaults are collected from publicly available information provided in the 'Annual Global Corporate Default Study and Rating Transitions' by S\&P. The data covers 2005 q2 to $2010 \mathrm{q} 4$ and includes the company name, plus the date and amount of the default. ${ }^{5}$ Next, the industry default data are supplemented by industry classification codes from Thompson One Banker or EDGAR. Subsequently, out of 399 defaults on S\&P rated debt, we retain in our sample 340 which could be matched to a primary NAICS or, if unavailable, to a primary SIC industry. The coverage of the major defaults is presented in Table 3.1 Panel B. If there are multiple major defaults in one industry at the same time, we count it as a one industry default. So there are 255 unique industry defaults of total value $\$ 894,475$ million and never less than 2 industry defaults per quarter. Panel A of Figure 3.4 illustrates the evolution of the industry default events in the final sample of industry defaults, with defaults occurring most frequently in 2009 q2 (57 industry defaults), with the highest amount in default in 2009 q1 (mil \$12,572.60).

The second independent variable, Post, is a dummy variable that takes the value of one in a quarter following industry default in a linked

\footnotetext{
${ }^{5}$ It is important to note that the industry default rate is calculated from a different data sample than that which includes data about small businesses. We compute a small business default rate from this data set in a separate calculation. Since such an industry default is a 'major' default on S\&P rated debt, it does not become part of the sample of small businesses for which we test for the presence of ripple effects. In general if a competitor is in distress at time $t$, it is excluded from the cohort of financially sound firms in non-defaulted state which comprises the base of our default rate computation. Therefore the default of a competitor at time $t$ does not have any effect on the default rate at the same time, but rather it is included in $t-1$.
} 
(a)

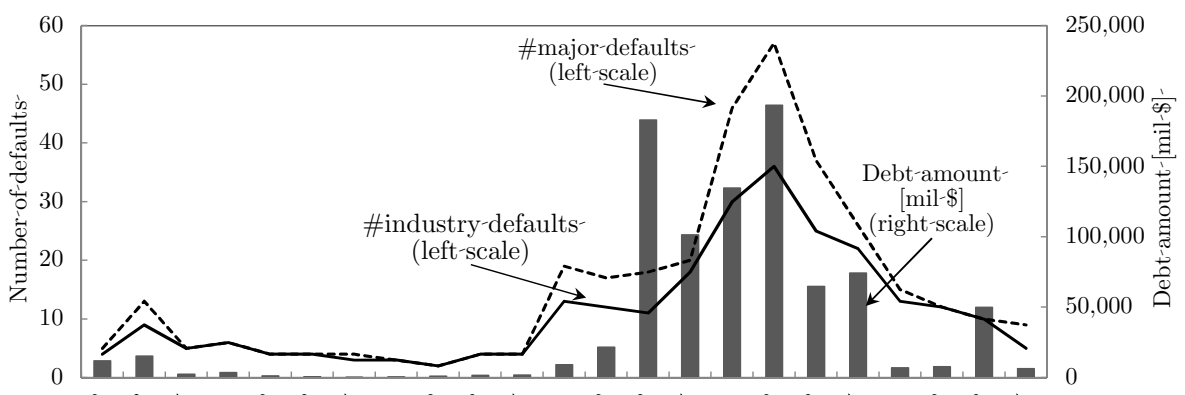

(b)
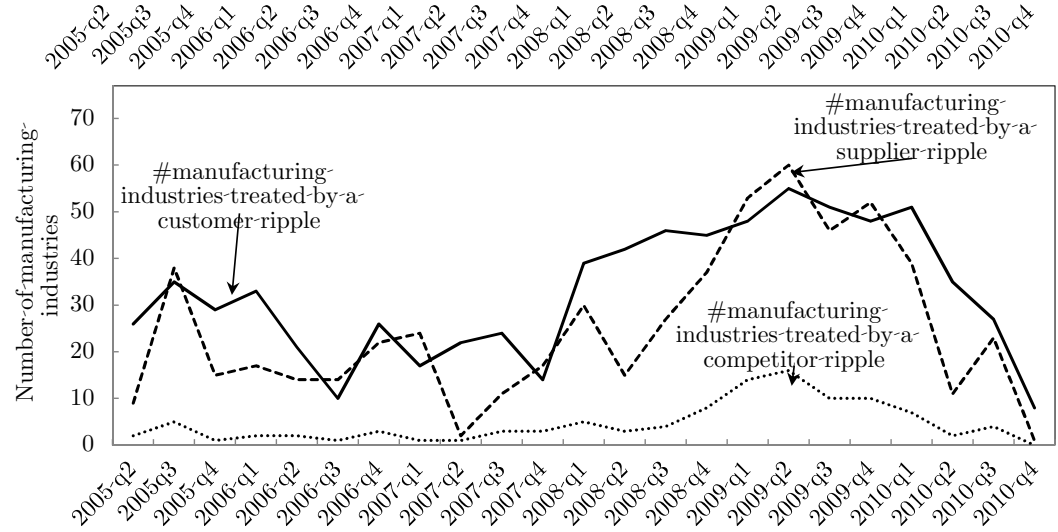

(c)-

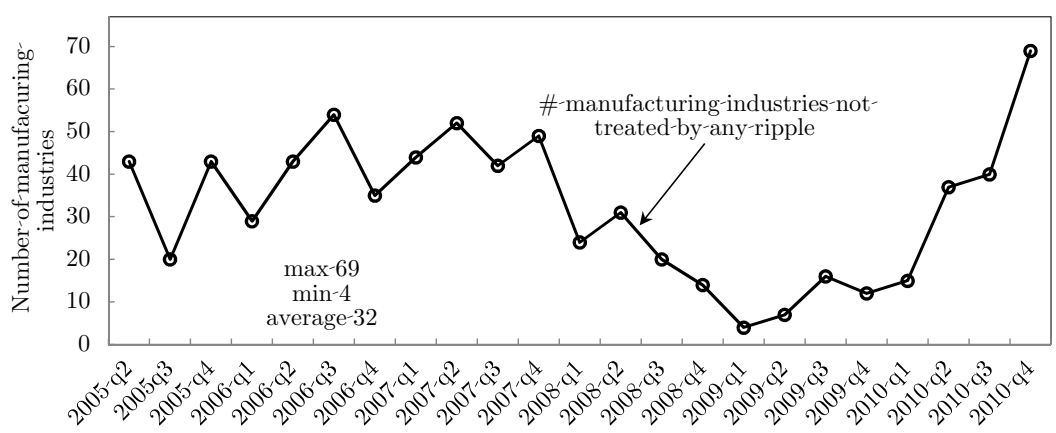

Figure 3.4: Industry defaults and major defaults. Panel (a) presents time series pattern in industry defaults, number of major defaults on the U.S. S\&P rated debt and the debt amount on which the major defaults occurred from 2005 q2 to 2010 q4. Some of the major defaults in one industry fall on the same quarter, so there are 254 unique industry defaults compared to 340 major defaults. Out of the 255 unique industry defaults, 107 occurred in manufacturing industries. Panel (b) presents the number of manufacturing industries that were treated by customer, supplier or competitor ripple and Panel (c) that were not. There are 77 manufacturing industries in total.

industry. In principle, any manufacturing industry can be affected by a customer, supplier or competitor ripple or by any combination of these. The number of manufacturing industries treated by either type of ripple effect is presented in Panel B of Figure 3.2. At any point in time there 
are some industries that are affected by any of the ripples. Panel $\mathrm{C}$ of Figure 3.2 shows the number of industries that are not under any type of treatment. Those industries serve as a control group, i.e. to a pure customer ripple, pure supplier ripple and pure competitor ripple. The number is lowest during the recession when there are only 4 industries not under any treatment. On average during the entire sample period, there are 32 industries not under any treatment. Also, all industries are treated at some point in time.

The linkages between industries are determined based on the Make and Use tables of industry Input-Output (IO) accounts which contain the flows of intermediate inputs in the economy. The IO data are provided by the U.S. Bureau of Labor Statistics on an annual basis for years 1993-2010 and are derived from the U.S. Bureau of Economic Analysis. ${ }^{6}$ We assume industries are linked if a proportion of outputs supplied to or a proportion of intermediate products purchased from a given industry is greater than $1 \%$ (for more detailed description please refer to Appendix B).

\subsubsection{Industry features}

We are interested to see whether a concentration of small business loan portfolios into large, interconnected or concentrated industries affects the magnitude of ripple effects. To measure the industry size, we take the number of establishments from the U.S. Census Bureau County Business Patterns. This annual information is derived from the Census Bureau's Business Register which is the most comprehensive data set on U.S. business activities. Establishments are defined as single physical locations, thus larger firms tend to have more establishments. We aggregate the data into IO industries following the mapping described in Appendix B.

Second, the interconnectedness of an industry is computed from U.S. Bureau of Labor Statistics IO data. It is calculated as a sum of all existing inter-industry input-output relationships with IO industries of a value greater than $1 \%$.

Lastly, we measure industry concentration by industry markup, which is the price-cost margin in an industry. Industrial organization theory predicts a positive relationship between industry concentra-

${ }^{6}$ The most recent release of detailed IO tables by U.S. Bureau of Economic Analysis dates back to 2002. However our sample covers 2005 q2 to 2011 q4. 
tion and industry markup. In particular, more concentrated industries are expected to have lesser competition and can set price further from marginal cost. We follow methodology by Allayannis and Ihrig (2001) and Ali, Klasa, and Yeung (2009) and calculate the price-cost margin as:

$$
\mathrm{PCM}=\frac{\text { Value of sales }+\Delta \text { Inventories }- \text { Payroll }- \text { Cost of materials }}{\text { Value of sales }+\Delta \text { Inventories }}
$$

Given the U.S. Census definition of value added it is equal to (Value added - Payroll) $/$ (Value added + Cost of materials). The annual data used to calculate this measure comes from the U.S. Census Bureau Annual Survey of Manufactures. ${ }^{7}$

\subsubsection{Controls}

We collect industry level controls that include an indicator if an industry experiences a major default within one year. We derive it from the 'Annual Global Corporate Default Study and Rating Transitions' provided by S\&P. The share of large firms that employ more than 100 people, share of young firms that are less than 3 years old, and median D\&B credit score (CPOINTS) ${ }^{8}$ are also expected to play a role in the small business default rates. For example, young firms have high mortality rate and can be more sensitive to a changing business environment. We compute it from the $\mathrm{D} \& \mathrm{~B}$ data set. In our analysis we also include an indicator of whether the industry has only one customer, and an indicator of whether the industry has only one supplier. In general, such focused industries are expected to have higher default rates. This information comes from the IO tables. Additionally, to control for demand and supply shocks we include industry's sales and inventories. This information is provided by U.S. Census Bureau Annual Survey of Manufactures.

\footnotetext{
${ }^{7}$ We aggregate the data items per IO industry following the NAICS and IO mapping discussed in Appendix B.

${ }^{8}$ The credit score predicts a firm's likelihood of becoming delinquent during the next one year period. In its computation D\&B takes into account payments 90 days overdue, relief from creditors or incomplete payments. It ranges from 100 to 670 , assigning likelihood of delinquency between $2.10-61.50 \%$ respectively.
} 


\subsection{Main Results}

In this section particular interest is paid to evolution of industry defaults along the production process and the response they cause in default rates among small businesses. We use the term ripple effect to describe this reaction in small business credit worthiness. This paper distinguishes three types of ripple effects: a customer, supplier and competitor ripple. The last one affects competitors in the defaulting industry. The obtained results are shown to have risk management application in portfolios of loans to small businesses.

\subsubsection{Ripple effects in industry default rates among small manufacturing firms}

Our main results are presented in Table 3.2. It shows that default rates among small businesses are significantly higher in the quarter following a major default in an industry which buys their products or which is in the same industry. As expected, the coefficients on the difference-indifference terms: Dose $_{C u} \times$ Post $_{C u}$ and Dose $_{C o} \times$ Post $_{C o}$ are positive and significant. So the more severe the treatment, as measured by the amount in default relative to industry's assets, the greater the damage to the small business' creditworthiness. The effect is also economically significant. Also, in the case of distress in a customer industry a one standard deviation increase in the $D_{o s e}$ cu is followed by a 9.8 basis point increase in small business default rate in the supplying industries (regression in column (1)). The effect is even greater if industry default occurs in the same industry. In this case, one standard deviation increase in Dose $_{C o}$ is followed by a 12.5 basis point increase in small business default rates in the same industry.

We perform five regressions. In the first we include only the differencein-difference terms together with time and industry fixed effects. In column (2) to (5) of Table 3.2 we control if an industry experiences a major default within one year, or for industry's share of large firms, share of young firms and the median credit score. Intuitively, industries linked along the production process may share some commonalities which make them sensitive to common shocks. A systematic shock to a group of industries should then be reflected in those controls. For example young firms are among the first to default as they are vulnerable due to their new client base and their small capital buffers making 
Table 3.2

\section{Ripple effects on industry default rates among small manufacturing firms}

This table shows pooled OLS regression estimates (\%) based on an industry-quarter observations from manufacturing industries. The dependent variable is the small business default rate which measures the rate at which active and financially sound small businesses default within one year. Regression (4) assumes that industry is treated for two quarters following the shock rather than for one. Regression (5) includes the year-times-industry fixed effects. The figures in square brackets represent a percentage change in the small business default rate to a one standard deviation change in a given covariate. Standard errors are calculated by clustering at industry level and are reported in parenthesis. Significance is denoted by $*$ at the $90 \%$ level, ** at the $95 \%$ level and *** at $99 \%$ level.

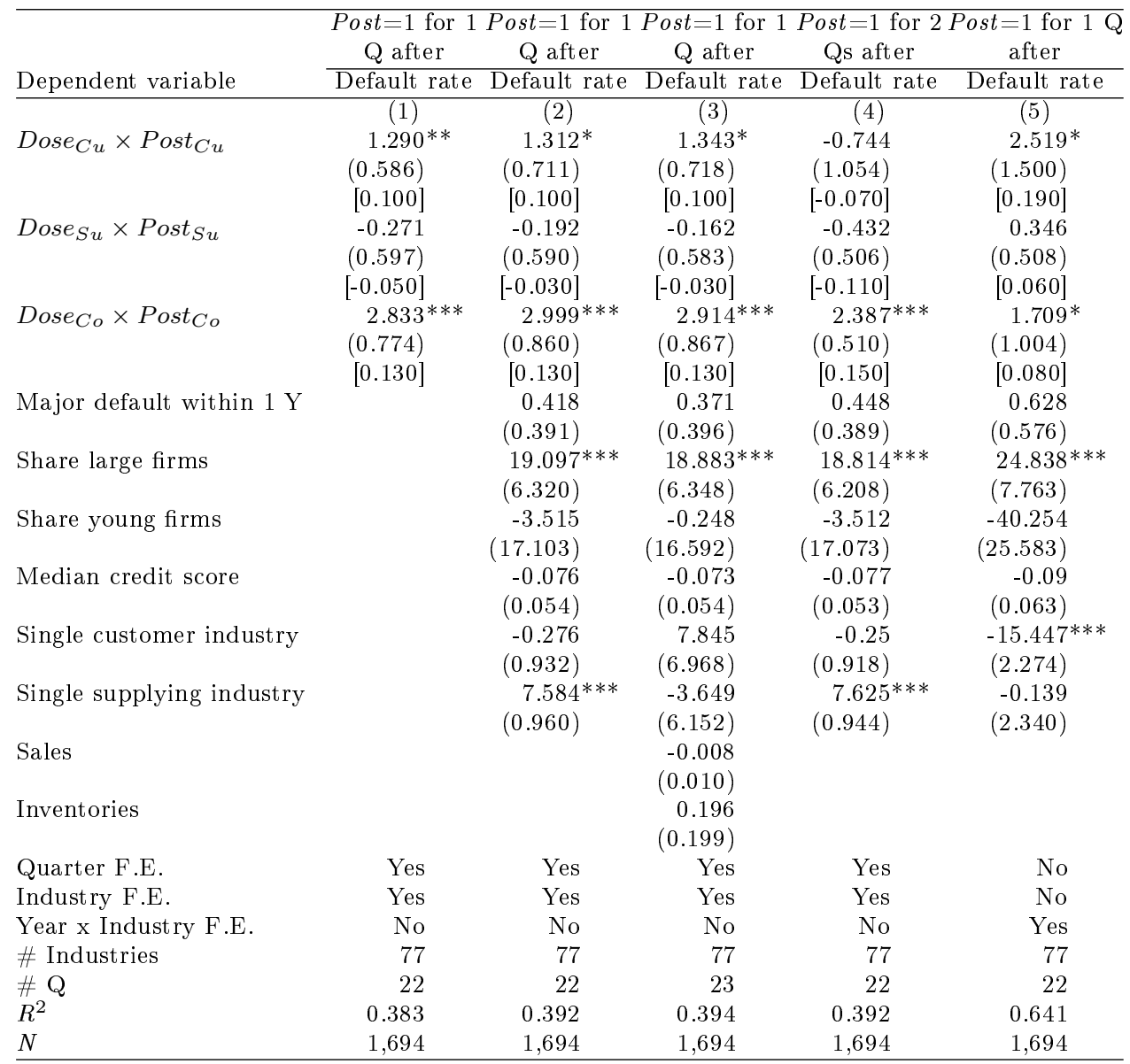

it difficult to withstand losses. Also, credit risk measured as median credit score can reflect a common shock if it alters the firm's credit worthiness.

Also, holding considerable inventories can work as a cushion in the event of a failure by a supplier. Although supplier failure is associ- 
ated with losses on advance payments, holding inventories minimizes disruption to the production process and allows firms to continue to produce. From this point of view, industries with low inventories are more vulnerable to distress in their supplier industry as supplier default can cause a halt in production. This in turn leads to higher volatility of default rates. Apart from the above supply side shock, a common shock can come from the demand side i.e. a drop in sales. However, our results are robust to the inclusion of the sales and inventories ${ }^{9}$ variables in column (3). The ripple effect remains valid even 2 quarters afterward, but only for the competitor ripple as is shown in column (4).

Although the potential level of Dose is captured by the industry fixed effects, we would like to address any concern that Dose might not be constant throughout the time-by-time varying (annual) industry fixed effects. This captures a non-trivial part of the data variability. In this case the identification of the ripple effect comes from the intraannual variability in small business default rates. Results with the time varying industry fixed effects are presented in column (5) in Table 3.2 and the basic message remains unaffected.

Therefore even though industry default is not unanticipated, it serves as an indicator of the severity of financial distress in the defaulting firm. Prior to an industry default, if the major firm experiences liquidity shortage it consequently renegotiates or delays its liabilities, i.e. by postponing payments to its suppliers or delivery to its customers. So although a default on $\mathrm{S} \& \mathrm{P}$ rated debt does not affect small private firms on its own (since their direct exposure to this type of debt is rather limited) one has to bear in mind that industry default is merely an indicator of a process which takes place prior to it. In particular, credit chains which form (through production to order linkages) for most intermediate goods are especially vulnerable to this process. By default, this production process takes time, plus the output is clientspecific and can only be finalized by the specific supplier. Typically, the payment cannot be simultaneous with the production process, but instead the first part is paid up-front to secure the supplier's interests and the rest at the completion to secure the customer's interests. The second payment is therefore a debt repayment and is subject to credit risk (Kiyotaki and Moore (2002)). Also the industry default indicates

\footnotetext{
${ }^{9}$ Variable sales and inventories are taken from U.S. Census Bureau Annual Survey
} of Manufactures. 
that the industry is in imminent distress such that a larger number of small businesses can be affected.

As during the recession most industries were under at least one type of treatment, the OLS regression could be criticized for comparing prerecession industries to the ones during recession. To address this issue we use the matching estimation approach in which we focus on the pre-recession (pre December 2007) period. This way we also alleviate a concern that our results are affected by the credit crunch that occurred during the recession. A credit crunch can force more small businesses to default on their payments due to their being unable to roll-over their credit. Although in OLS estimations a credit crunch should be captured by the quarterly fixed effects, the matching estimation approach is a robust, non-parametric approach that can address both concerns.

Ideally, we would like to compare the default rates in an industry under treatment (ripple effect) to default rates in the same industry which had not been subject to the same treatment (ripple effect). Because we are unable to observe the counterfactual, we aim to approximate it by looking at another industry that mimics the treated industry in all aspects except that it is treated by some given ripple effect (for discussion on application of matching estimator refer to Malmendier and Tate (2009)). To this end, we use the Abadie and Imbens (2007) matching estimation approach. We match exactly, in the same quarter, industries which were treated by a given ripple, with those that were not treated by the same ripple. Matched industries are chosen from all non-treated industries in the same quarter such that they are the closest match based on: all the control we used in regressions in Table 3.2. Additionally, for customer ripple, the match is done on: Dose during supplier treatment, Dose under competitor treatment; for supplier ripple on: Dose during customer treatment, Dose under competitor treatment; and for competitor ripple on: Dose during customer treatment, Dose during supplier treatment. By doing this we want to capture the incremental difference in default rates that is due to the specific ripple. So imagine an industry treated by customer and supplier ripple. To measure the customer ripple, it will be matched to another industry that should resemble it in all dimensions other than the customer ripple. So, the matched industry should not be treated by customer ripple but by a supplier ripple.

Table 3.3 presents the descriptive statistics of treated industries side by side with the non-treated and matched industries. The difference between treated industries and the entire sample is reported in columns 
(R-A) and the difference between treated industries and the matched sample is reported in column (R-M). We test if those differences are equal to zero. Among the variables used in the regressions and in the matching, three are significantly different at $1 \%$ level between industries treated by customer ripple and all those that are not treated by customer ripple, but only one between the treated and matched. Similarly, Panel B shows that three variables are significantly different at $1 \%$ level between industries treated by supplier ripple and all those that are not treated by supplier ripple, but only one between the treated and matched. In case of competitor ripple, the treated industries differ with respect to one variable at $1 \%$ level of significance while not showing any significant difference to the matched sample.

The principal ripple effect for U.S. manufacturing small businesses is measured by the average treatment effect in Table 3.4. The average treatment effect is positive, indicating higher default rates among small businesses following an industry default in a linked industry. Economically, one quarter after industry default, the difference in default rates between treated and matched industries ranges from $0.57 \%$ to $2.62 \%$, depending on ripple type. The most pronounced difference is observed in the pre-recession period after distress in same industry. As expected, distress in a linked industry translates into a significant negative welfare effect for small businesses. It significantly reduces small businesses' credit worthiness. Overall, the production relationships are a strong channel through which negative welfare effects spread and weaken the performance of production partners. Figure 3.5 illustrates the development of default rates in industries treated by the ripple effect and the matched sample. In most cases, the default rates among small businesses respond by increasing right after the industry default, and then tend to converge toward the matched sample 3 quarters afterward.

\subsubsection{Ripple effect and market structure}

We continue our analysis in Table 3.5 by exploring the effect of portfolio concentration on the magnitude of ripple effects. We investigate if large, more interconnected and more concentrated industries are more vulnerable to treatment by ripple effect. We expect that small businesses in industries with greater size (number of establishments) are subject to lower ripple effects. It means that in sizable industries the damage to an industry's credit worthiness is lower as this variable is measured relative to the number of establishments. The damage is 
therefore contained to a smaller share of firms that suffer a shock to their firm value. This in turn decreases the ripple effect in large industries.

Also, we anticipate a non-linear relationship between ripple effect

Table 3.3

\section{Summary statistics for industries receiving ripple in the pre-recession period}

The table shows descriptive statistics for manufacturing industries treated by ripple effect, all manufacturing industries not treated by ripple effect and a control (matched industries). Each treated industry is matched to one non-treated manufacturing industry. The matched industries are chosen from all non-treated industries in the same quarter such that they are the closest match based on: major default within one year, share of large firms, share of young firms, median credit score, whether the industry has only one customer, whether the industry has only one supplier, sales and inventories. Additionally, for customer ripple the match is done on: dose during supplier treatment, dose under competitor treatment; for supplier ripple on: dose during customer treatment, dose under competitor treatment; and for competitor ripple on: dose during customer treatment, dose during supplier treatment. We allow for heteroscedasticity in standard errors (4 matches). The sample runs from 2005 q3 to 2007 q3 and includes 77 industries in 9 quarters. Panel A compares industries under treatment by a customer ripple $(\mathrm{R})$ with those that are intact by any customer ripple (A) and with the matched sample (M). Panel B does the same for industries under treatment by supplier ripple and Panel $\mathrm{C}$ for industries under treatment by competitor ripple. The column (R-A) reports the two-sample t-test for difference in means between the treated industries and all non-treated. The column (R-M) reports the two-sample t-test for difference in means between the treated industries $(R)$ and the matched industries $(M)$. Standard errors are in parenthesis. Significance is denoted by * at the $90 \%$ level, ${ }^{* *}$ at the $95 \%$ level and *** at $99 \%$ level.

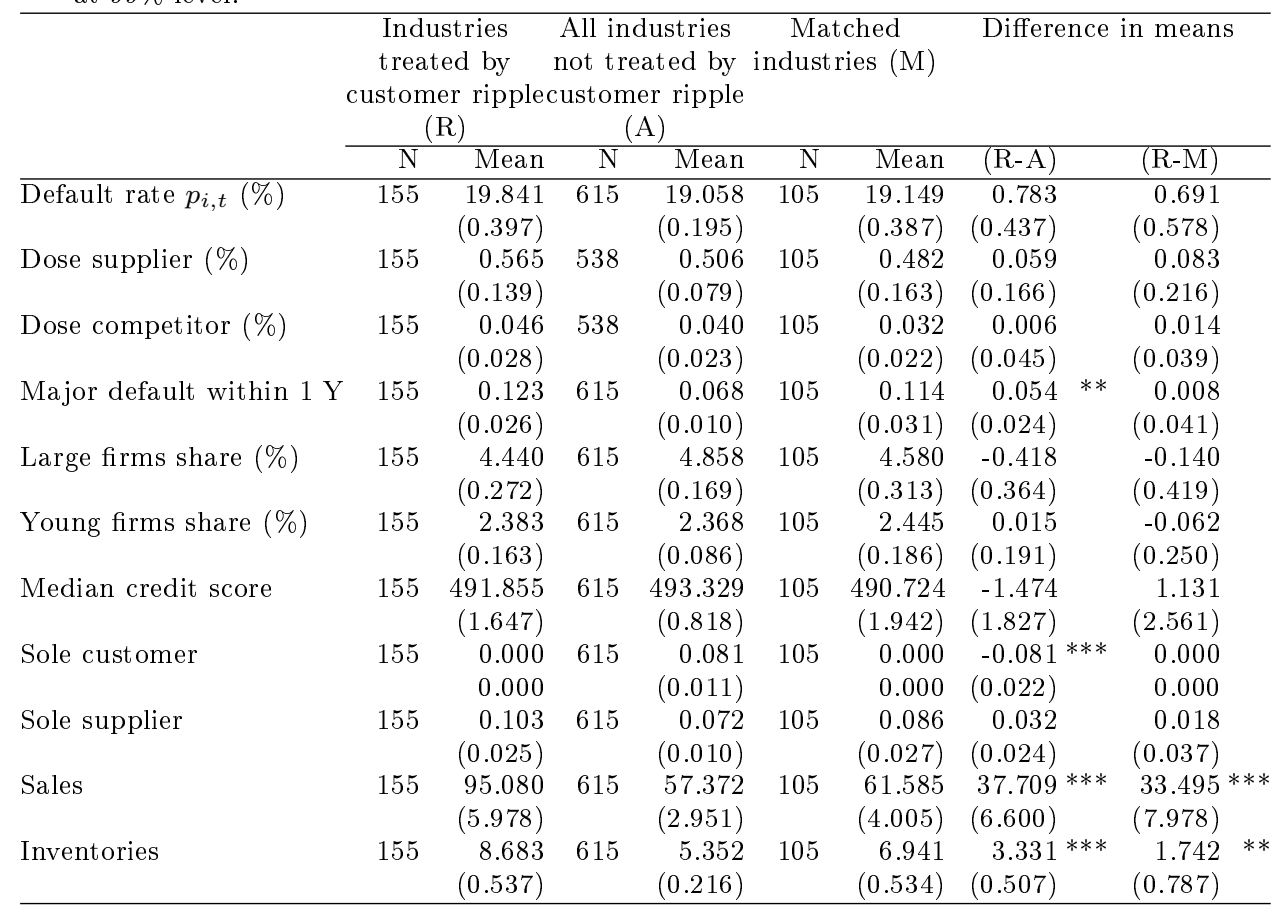


Continued from previous page

Panel B: Supplier ripple

Industries All industries Matched Difference in means

treated by not treated by industries (M)

supplier ripple supplier ripple

\begin{tabular}{|c|c|c|c|c|c|c|c|c|c|}
\hline & \multicolumn{2}{|c|}{$(\mathrm{R})$} & \multicolumn{2}{|c|}{ (A) } & \multirow[b]{2}{*}{$\mathrm{N}$} & \multirow[b]{2}{*}{ Mean } & \multirow[b]{2}{*}{$(\mathrm{R}-\mathrm{A})$} & \multirow{2}{*}{\multicolumn{2}{|c|}{$(\mathrm{R}-\mathrm{M})$}} \\
\hline & $\mathrm{N}$ & Mean & $\mathrm{N}$ & Mean & & & & & \\
\hline \multirow[t]{2}{*}{$\overline{\text { Default rate } p_{i, t}(\%)}$} & 219 & 19.741 & 551 & 19.006 & 148 & 19.646 & 0.735 & * & 0.095 \\
\hline & & $(0.328)$ & & $(0.207)$ & & $(0.351)$ & $(0.388)$ & & $(0.493)$ \\
\hline \multirow[t]{2}{*}{ Dose supplier (\%) } & 219 & 0.143 & 474 & 0.193 & 148 & 0.164 & -0.05 & & -0.021 \\
\hline & & $(0.035)$ & & $(0.036)$ & & $(0.046)$ & $(0.058)$ & & $(0.057)$ \\
\hline \multirow[t]{2}{*}{ Dose competitor $(\%)$} & 219 & 0.024 & 474 & 0.049 & 148 & 0.022 & -0.025 & & 0.002 \\
\hline & & $(0.015)$ & & $(0.026)$ & & $(0.021)$ & $(0.040)$ & & $(0.025)$ \\
\hline \multirow[t]{2}{*}{ Major default within $1 \mathrm{Y}$} & 219 & 0.110 & 551 & 0.067 & 148 & 0.061 & 0.042 & $* *$ & 0.049 \\
\hline & & $(0.021)$ & & $(0.011)$ & & $(0.020)$ & $(0.022)$ & & $(0.030)$ \\
\hline \multirow[t]{2}{*}{ Large firms share (\%) } & 219 & 4.621 & 551 & 4.835 & 148 & 4.176 & -0.213 & & 0.446 \\
\hline & & $(0.247)$ & & $(0.179)$ & & $(0.243)$ & $(0.324)$ & & $(0.361)$ \\
\hline \multirow[t]{2}{*}{ Young firms share (\%) } & 219 & 2.294 & 551 & 2.402 & 148 & 2.336 & -0.107 & & -0.042 \\
\hline & & $(0.141)$ & & $(0.091)$ & & $(0.160)$ & $(0.169)$ & & $(0.216)$ \\
\hline \multirow[t]{2}{*}{ Median credit score } & 219 & 492.790 & 551 & 493.129 & 148 & 490.193 & -0.339 & & 2.597 \\
\hline & & $(1.367)$ & & $(0.868)$ & & $(1.544)$ & $(1.624)$ & & $(2.092)$ \\
\hline \multirow[t]{2}{*}{ Sole customer } & 219 & 0.023 & 551 & 0.082 & 148 & 0.034 & -0.059 & $* *$ & -0.011 \\
\hline & & $(0.010)$ & & $(0.012)$ & & $(0.015)$ & $(0.020)$ & & $(0.017)$ \\
\hline \multirow[t]{2}{*}{ Sole supplier } & 219 & 0.009 & 551 & 0.105 & 148 & 0.027 & -0.096 & *** & -0.018 \\
\hline & & $(0.006)$ & & $(0.013)$ & & $(0.013)$ & $(0.021)$ & & $(0.013)$ \\
\hline \multirow[t]{2}{*}{ Sales } & 219 & 86.338 & 551 & 56.467 & 148 & 59.669 & 29.871 & *** & $26.669 * * *$ \\
\hline & & $(7.079)$ & & $(2.427)$ & & $(3.874)$ & $(5.892)$ & & $(9.185)$ \\
\hline \multirow[t]{2}{*}{ Inventories } & 219 & 7.651 & 551 & 5.376 & 148 & 6.508 & 2.275 & $* * *$ & 1.143 \\
\hline & & $(0.407)$ & & $(0.237)$ & & $(0.477)$ & $(0.456)$ & & $(0.632)$ \\
\hline
\end{tabular}

Panel C: Competitor ripple

Industries All industries Matched Difference in means

treated by not treated by industries (M)

competitor competitor

ripple $(\mathrm{R}) \quad$ ripple $(\mathrm{A})$

\begin{tabular}{|c|c|c|c|c|c|c|c|c|c|}
\hline & \multicolumn{2}{|c|}{ ripple (R) } & \multicolumn{2}{|c|}{ ripple $(\mathrm{A})$} & \multirow[b]{2}{*}{$\mathrm{N}$} & \multirow[b]{2}{*}{ Mean } & \multirow[b]{2}{*}{$(\mathrm{R}-\mathrm{A})$} & \multirow{2}{*}{\multicolumn{2}{|c|}{$(\mathrm{R}-\mathrm{M})$}} \\
\hline & $\mathrm{N}$ & Mean & $\mathrm{N}$ & Mean & & & & & \\
\hline \multirow{2}{*}{$\overline{\text { Default rate } p_{i, t}(\%)}$} & 18 & 21.562 & 752 & 19.159 & 18 & 19.375 & 2.403 & $* *$ & 2.187 \\
\hline & & $(1.030)$ & & $(0.178)$ & & $(1.116)$ & $(1.159)$ & & $(1.519)$ \\
\hline \multirow[t]{2}{*}{ Dose supplier $(\%)$} & 18 & 0.208 & 675 & 0.178 & 18 & 0.150 & 0.052 & & -0.023 \\
\hline & & $(0.160)$ & & $(0.028)$ & & $(0.057)$ & $(0.170)$ & & $(0.096)$ \\
\hline \multirow[t]{2}{*}{ Dose competitor (\%) } & 18 & 0.127 & 675 & 0.527 & 18 & 0.453 & -0.32 & & -0.245 \\
\hline & & $(0.077)$ & & $(0.071)$ & & $(0.235)$ & $(0.434)$ & & $(0.284)$ \\
\hline \multirow{2}{*}{ Major default within $1 \mathrm{Y}$} & 18 & 0.278 & 752 & 0.074 & 18 & 0.278 & 0.203 & *** & 0.000 \\
\hline & & $(0.109)$ & & $(0.010)$ & & $(0.109)$ & $(0.064)$ & & $(0.154)$ \\
\hline \multirow{2}{*}{ Large firms share (\%) } & 18 & 5.563 & 752 & 4.755 & 18 & 4.820 & 0.808 & & 0.743 \\
\hline & & $(1.445)$ & & $(0.146)$ & & $(0.703)$ & $(0.967)$ & & $(1.607)$ \\
\hline \multirow{2}{*}{ Young firms share (\%) } & 18 & 2.455 & 752 & 2.369 & 18 & 2.507 & 0.086 & & -0.052 \\
\hline & & $(0.457)$ & & $(0.077)$ & & $(0.467)$ & $(0.506)$ & & $(0.654)$ \\
\hline \multirow[t]{2}{*}{ Median credit score } & 18 & 493.472 & 752 & 493.022 & 18 & 494.250 & 0.45 & & -0.778 \\
\hline & & $(4.686)$ & & $(0.742)$ & & $(5.212)$ & $(4.850)$ & & $(7.009)$ \\
\hline \multirow[t]{2}{*}{ Sole customer } & 18 & 0.000 & 752 & 0.066 & 18 & 0.000 & -0.066 & & 0.000 \\
\hline & & 0.000 & & $(0.009)$ & & 0.000 & $(0.059)$ & & 0.000 \\
\hline \multirow[t]{2}{*}{ Sole supplier } & 18 & 0.000 & 752 & 0.080 & 18 & 0.000 & -0.08 & & 0.000 \\
\hline & & 0.000 & & $(0.010)$ & & 0.000 & $(0.064)$ & & 0.000 \\
\hline \multirow[t]{2}{*}{ Sales } & 18 & 101.625 & 752 & 64.085 & 18 & 81.796 & 37.54 & ** & 19.829 \\
\hline & & $(17.863)$ & & $(2.725)$ & & $(14.600)$ & $(17.832)$ & & $(23.070)$ \\
\hline \multirow[t]{2}{*}{ Inventories } & 18 & 8.670 & 752 & 5.960 & 18 & 6.911 & 2.711 & $* *$ & 1.759 \\
\hline & & $(1.278)$ & & $(0.211)$ & & $(1.039)$ & $(1.379)$ & & $(1.647)$ \\
\hline
\end{tabular}


Table 3.4

\section{Ripple effects in the pre-recession period - matching estimator approach}

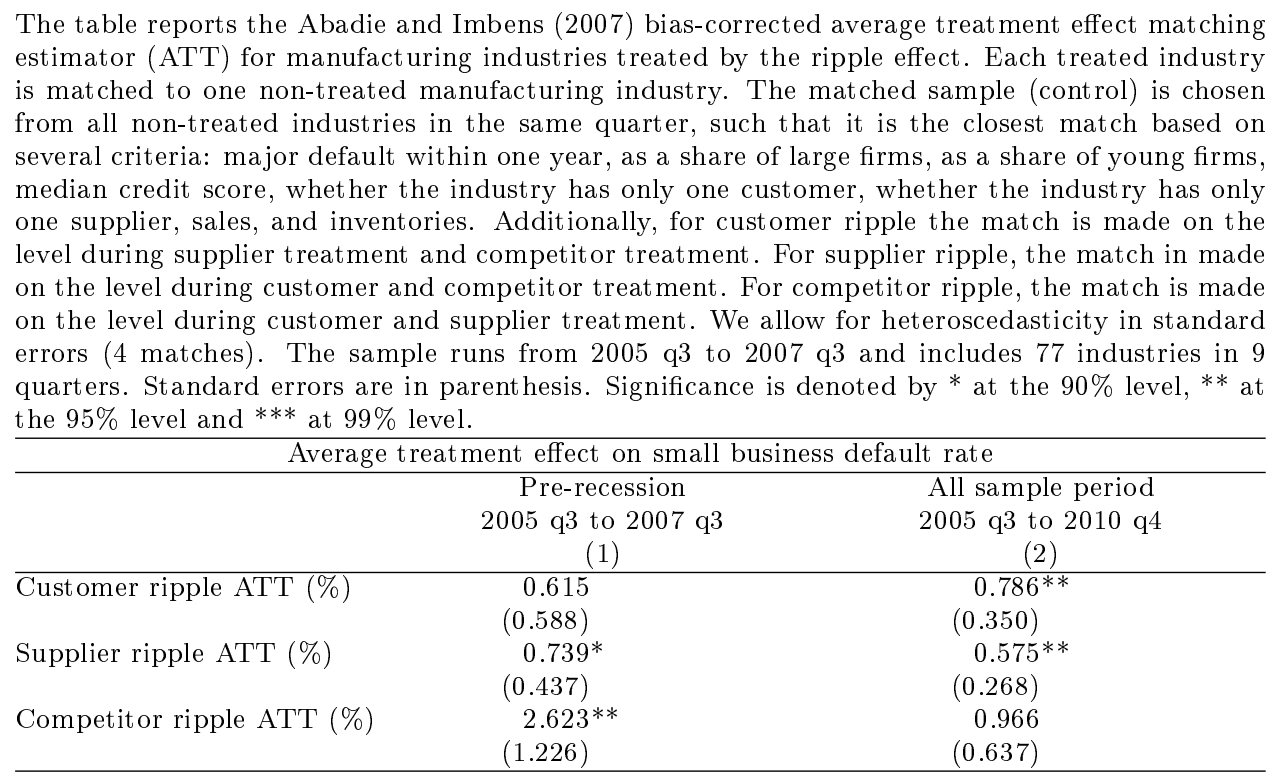

and interconnectedness. We expect lower ripple effect for more interconnected industries that have greater number of bilateral connections between industries. The more interconnected is the industry, the more diverse the economic activity. This potentially allows for diversification of the counterparty risk. On the other hand, the more interconnected industries are exposed to shocks of various origins. Therefore industries with wide connections serve as a hub for the transmission of default risk; they become more easily infected and at the same time infect their counterparties.

We expect lesser ripple effects in concentrated industries as the firms can have an opportunity to seize new market share that is lost by the distressed competitor. In consequence, they are able to gain market power and benefit from some form of monopoly Lang and Stulz (1992). In sum, the ripple effect is expected to be stronger in small and isolated industries with low concentration.

Table 3.5 show the result of regression (3.2). We include here an interaction term between the difference-in-difference terms and the industry feature as size, interconnectedness and concentration. Column (1) of Table 3.5 shows no significant relationship between ripple effect and an industry's size. Next, to account for an anticipated nonlinear re- 
(a) Pre-recession
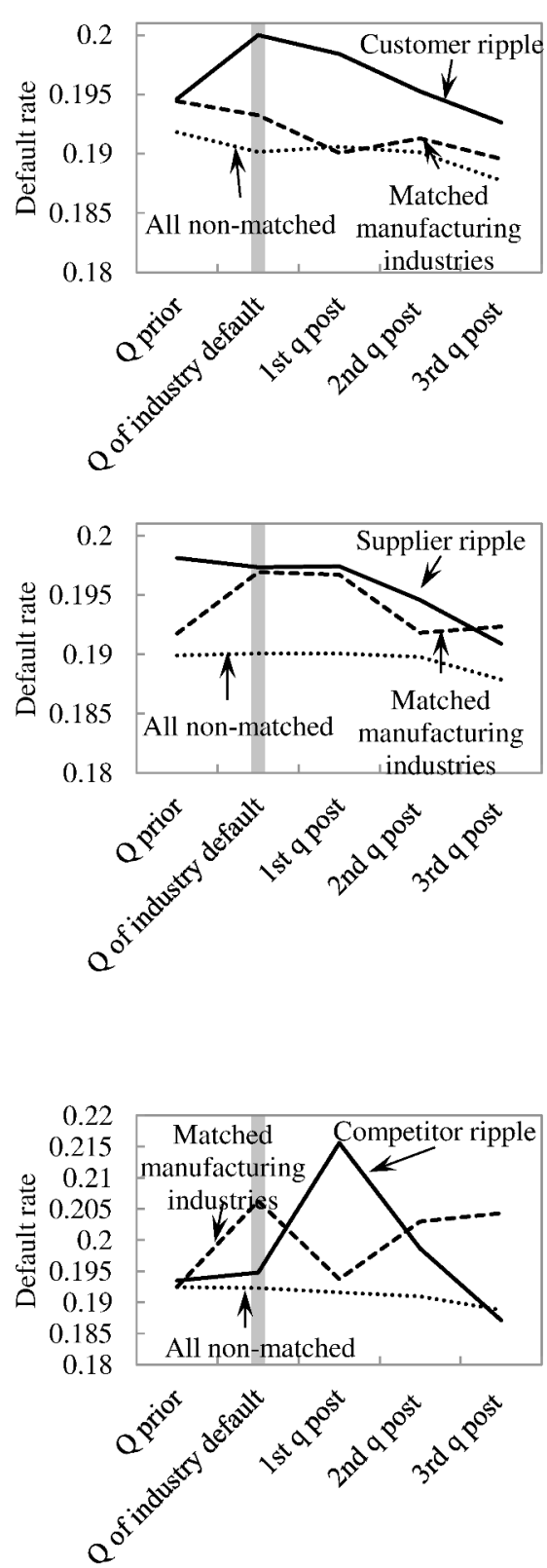

(b) Whole sample
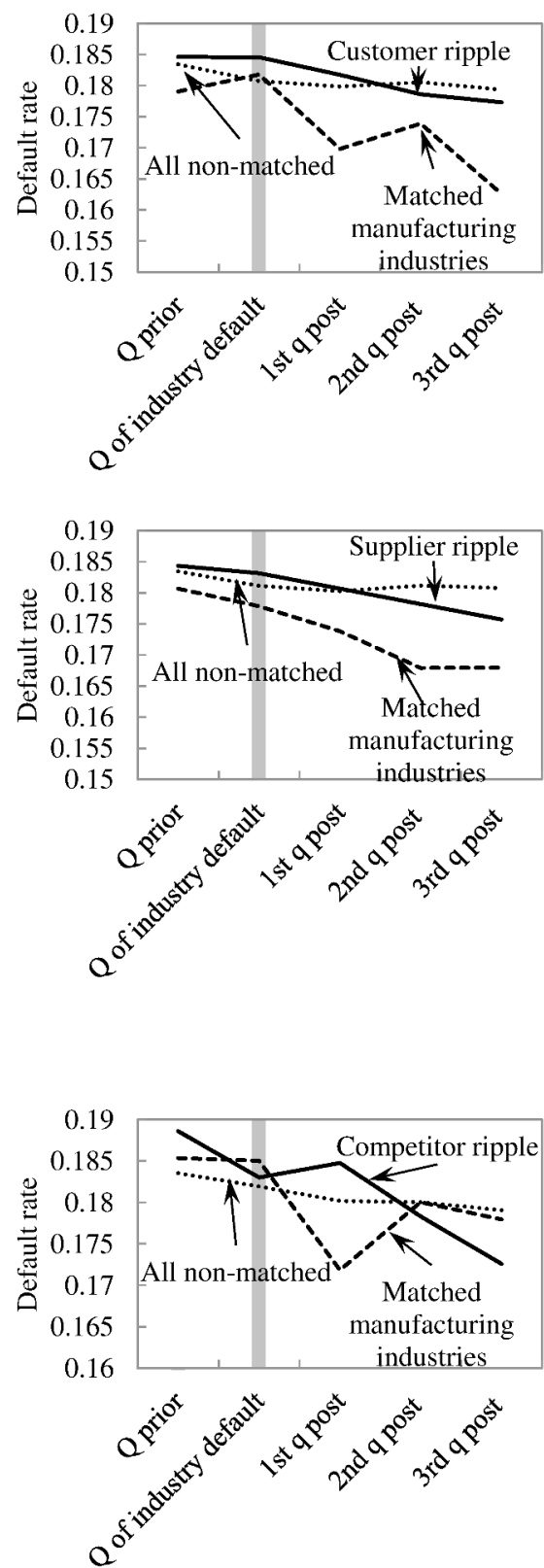

Figure 3.5: Default rates among small firms in the manufacturing industries. The figure presents default rates in U.S. small manufacturing firms around industry defaults in their customer or supplier industries or in their own industry.

lationship between interconnectedness and the ripple effect we include an additional interaction term with interconnectedness squared. Column (2) presents the ripple effect for more interconnected industries. 
We observe no straightforward effect of interconnectedness on the magnitude of ripple effect, although, in general, more interconnected industries enjoy lower default rates, which reveals some diversification benefits. Importantly, the last column confirms that firms in highly concentrated industries can benefit from distress of other firms. In this case, they are able to, for example, step in and take over market share following distress in a customer industry (positive and significant coefficient on Feature $\times$ Dose $_{C u} \times$ Post $_{C u}$ ). Holding a portfolio of small business loans operating in concentrated industries helps to mitigate counterparty risk and, therefore, ripple effect. The results show that an average industry (with respect to concentration) experiences a 0.005 basis point increase in default rate following a treatment by an average Dose $_{C u}$. However, a one standard deviation more concentrated industry actually benefits of an industry default in its customer industry. In this case, we observe a decrease in small business default rates by 1.6 basis points.

In the matching estimator approach, we construct three portfolios containing largest, most interconnected or most concentrated industries from the top quintile. We report the resulting average treatment effects in Table 3.6. Panel A depicts the results for the pre-recession period and Panel B for the full sample period. In the full sample period and partially before the recession, larger industries treated by the ripple effect respond with a lower ripple effect than the matched sample. Thus the larger is the industry, the lower the relative damage to the production relationships. The damage is contained to a smaller share of firms that suffer a shock. Next, column (2) presents the ripple effect for interconnectedness portfolios. A trend is observed in which the industries with wide connections suffer lower ripple effect than the matched sample. Thus, our results suggest that there are diversification benefits in the more interconnected industries. Column (3) of Table 3.5 shows evidence that during full sample period the ripple effect lessens in highly concentrated industries. It is in line with previous research that reports a positive effect from default in concentrated industries. This pattern is, however, reversed prior to the recession, and can suggest that during this particular time period firms actually experienced contagion in default risk rather than competitive advantages. 
Table 3.5

\section{Industry features and ripple effects on industry default rates among small manufacturing firms}

This table shows pooled OLS regression results (\%) based on an industry-quarter observations for manufacturing industries. The dependent variable is small business default rate which measures the rate at which active and financially sound small businesses default within one year. All regressions contain controls as in Table 3.2, that is: major default within one year, share large firms, share young firms, median credit score, single customer industry, single supplying industry, sales, and inventories. Standard errors are calculated by clustering at industry level and are reported in parenthesis. Significance is denoted by $*$ at the $90 \%$ level, ** at the $95 \%$ level and $* * *$ at $99 \%$ level.

\begin{tabular}{|c|c|c|c|}
\hline Feature & Size & Inter-connectedness & Concentration \\
\hline & (1) & $(2)$ & $(3)$ \\
\hline \multirow[t]{2}{*}{$\operatorname{Dose}_{C u} \times$ Post $_{C u}$} & 1.519 & -102.127 & $5.265 * * *$ \\
\hline & $(1.227)$ & $(69.128)$ & $(1.168)$ \\
\hline \multirow[t]{2}{*}{ Dose $_{S u} \times$ Post $_{S u}$} & 0.414 & -2.369 & 1.382 \\
\hline & $(0.932)$ & $(8.626)$ & $(1.992)$ \\
\hline \multirow{2}{*}{ Dose $_{\text {Co }} \times$ Post $_{C o}$} & 7.201 & -147.948 & 14.405 \\
\hline & $(7.416)$ & $(242.097)$ & $(25.835)$ \\
\hline \multirow{2}{*}{ Feature $\times$ Dose $_{C u} \times$ Post $_{C u}$} & 0.000 & 6.065 & $-15.543 * * *$ \\
\hline & $(0.000)$ & $(3.881)$ & $(4.310)$ \\
\hline \multirow{2}{*}{ Feature $\times$ Dose $_{S u} \times$ Post $_{S u}$} & 0.000 & 0.107 & -3.961 \\
\hline & $(0.000)$ & $(0.713)$ & $(5.506)$ \\
\hline \multirow{2}{*}{ Feature $\times$ Dose $_{C o} \times$ Post $_{C o}$} & 0.000 & 9.198 & -35.772 \\
\hline & $(0.000)$ & $(12.931)$ & $(78.540)$ \\
\hline \multirow[t]{2}{*}{ Feature } & 0.000 & $-0.909 * *$ & 7.340 \\
\hline & $(0.000)$ & $(0.400)$ & $(7.068)$ \\
\hline \multirow[t]{2}{*}{ Feature $\times$ Post $_{C u}$} & 0.000 & -0.013 & 0.214 \\
\hline & $(0.000)$ & $(0.046)$ & $(0.787)$ \\
\hline \multirow[t]{2}{*}{ Feature $\times$ Post $_{S u}$} & 0.000 & -0.016 & 0.124 \\
\hline & $(0.000)$ & $(0.056)$ & $(0.956)$ \\
\hline \multirow[t]{2}{*}{ Feature $\times$ Post $_{C u}$} & 0.000 & 0.039 & 0.509 \\
\hline & $(0.000)$ & $(0.100)$ & $(1.444)$ \\
\hline \multirow{2}{*}{ Feature $^{2} \times$ Dose $_{C u} \times$ Post $_{C u}$} & & -0.086 & \\
\hline & & $(0.053)$ & \\
\hline \multirow{2}{*}{ Feature $^{2} \times$ Dose $_{S u} \times$ Post $_{\text {Su }}$} & & 0.000 & \\
\hline & & $(0.014)$ & \\
\hline \multirow[t]{2}{*}{ Feature $^{2} \times$ Dose $_{C o} \times$ Post $_{C o}$} & & -0.131 & \\
\hline & & $(0.169)$ & \\
\hline \multirow[t]{2}{*}{ Feature $^{2}$} & & $0.014^{* *}$ & \\
\hline & & $(0.006)$ & \\
\hline \multirow[t]{2}{*}{ Feature $^{2} \times$ Post $_{C u}$} & & 0.000 & \\
\hline & & $(0.001)$ & \\
\hline \multirow[t]{2}{*}{ Feature $^{2} \times$ Post $_{S u}$} & & 0.001 & \\
\hline & & $(0.002)$ & \\
\hline \multirow[t]{2}{*}{ Feature $^{2} \times$ Post $_{\text {Co }}$} & & -0.001 & \\
\hline & & $(0.003)$ & \\
\hline Controls & Yes & Yes & Yes \\
\hline Quarter F.E. & Yes & Yes & Yes \\
\hline Industry F.E. & Yes & Yes & Yes \\
\hline \# Industries & 77 & 77 & 77 \\
\hline$\# \mathrm{Q}$ & 22 & 22 & 22 \\
\hline$R^{2}$ & 0.394 & 0.399 & 0.395 \\
\hline$N$ & 1,694 & 1,694 & 1,694 \\
\hline
\end{tabular}

\subsubsection{Ripple effect and portfolio loss implication}

How does concentration into large, interconnected or concentrated industries relate to the counterparty risk and the ripple effect in portfo- 
Table 3.6

\section{Industry features and ripple effects in the pre-recession period - matching estimator approach}

The table reports the Abadie and Imbens (2007) bias-corrected average treatment effect matching estimator (ATT) for small business treated by the ripple effect. The 'high feature' sub-portfolios contain industries in the top quintile of a given feature. Each treated industry is matched to one non-treated manufacturing industry. The matched sample (control) is chosen from all non-treated industries in the same quarter such that it is the closest match based on: major default within one year, share of large firms, share of young firms, median credit score, whether the industry has only one customer and whether the industry has only one supplier, sales and inventories.

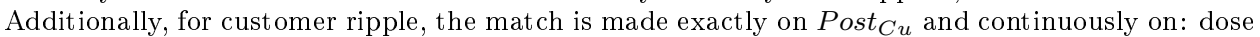
during supplier treatment, dose under competitor treatment; for supplier ripple exactly on Post Su $_{\text {in }}$ and continuously on: dose during customer treatment, dose under competitor treatment; and for competitor ripple exactly on Post $_{C o}$ and continuously on: dose during customer treatment, dose during supplier treatment. We allow for heteroscedasticity in standard errors (4 matches). The sample runs from 2005 q3 to 2007 q3 and includes 77 industries in 9 quarters. Standard errors are in parenthesis. Significance is denoted by * at the $90 \%$ level, ${ }^{* *}$ at the $95 \%$ level and *** at $99 \%$ level.

\begin{tabular}{|c|c|c|c|}
\hline \multicolumn{4}{|c|}{ Average treatment effect on small business default rate } \\
\hline & $\begin{array}{l}\text { High size } \\
\text { (1) }\end{array}$ & $\begin{array}{c}\text { High interconnectedness } \\
(2)\end{array}$ & $\begin{array}{c}\text { High concentration } \\
(3)\end{array}$ \\
\hline \multicolumn{4}{|l|}{ Panel A: Pre-recession period } \\
\hline \multirow[t]{2}{*}{ Customer ripple ATT (\%) } & $1.477 * *$ & $-1.995 * *$ & -0.499 \\
\hline & $(0.606)$ & $(0.954)$ & $(0.850)$ \\
\hline \multirow{2}{*}{ Supplier ripple ATT (\%) } & $-2.549 * * *$ & $-4.008 * * *$ & $2.055 * *$ \\
\hline & $(0.410)$ & $(0.541)$ & $(0.816)$ \\
\hline \multirow{2}{*}{ Competitor ripple ATT (\%) } & -0.990 & -1.193 & insufficient observations \\
\hline & $(1.782)$ & $(0.999)$ & \\
\hline \multicolumn{4}{|l|}{ Panel B: All sample } \\
\hline \multirow[t]{2}{*}{ Customer ripple ATT (\%) } & 0.107 & 0.662 & $-1.102 * *$ \\
\hline & $(0.323)$ & $(0.638)$ & $(0.469)$ \\
\hline \multirow[t]{2}{*}{ Supplier ripple ATT (\%) } & $-1.793 * * *$ & 0.143 & -0.384 \\
\hline & $(0.272)$ & $(0.433)$ & $(0.473)$ \\
\hline \multirow[t]{2}{*}{ Competitor ripple ATT (\%) } & 0.069 & 0.760 & -0.945 \\
\hline & $(0.820)$ & $(0.746)$ & $(2.201)$ \\
\hline
\end{tabular}

lios of loans to small businesses? To answer this question we bootstrap small business portfolios from historical data. Each portfolio contains small businesses distributed across 77 manufacturing IO industries proportionally to the historical data. To find the impact of ripple effect on portfolio default distribution, we consider two scenarios: one without any ripple effect and a second one with single ripple effect.

First, we create the unconditional loss distribution, in which we ignore the existence of ripple effect. The unconditional loss distribution is bootstrapped from the historical data in the following way: we randomly draw a quarter for each industry and take the number of defaults and total number of firms that were in that industry during that random quarter. Second, for the distribution with ripple effect we first randomly select a single industry default from historical data. Then we define the treated industries as linked industries (suppliers, customers 


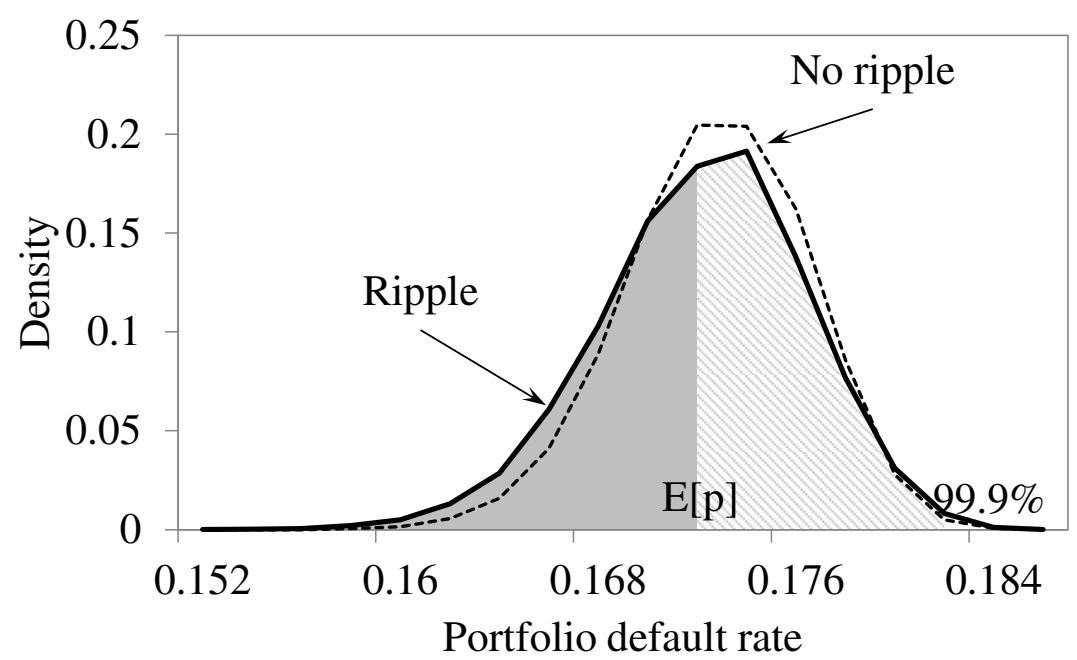

Figure 3.6: Portfolio default distribution This figure shows ripple effect from a single industry default for a diversified portfolio. The unconditional distribution is given by the dashed line and with ripple effects is given by the solid line. In the case of the portfolio with single ripple effect, the full shaded area depicts the expected losses on the diversified portfolio and the dashed shaded area depicts the unexpected losses up to 99.9 percentile.

or the same industry). For them we take the number of defaults and total number of firms that were in those industries for the following quarter. For the non-treated industries we repeat the process used for the unconditional distribution. We repeat that procedure 100.000 times to obtain distribution presented in Figure 3.6.

Figure 3.6 shows the outcome for a diversified portfolio including all 77 manufacturing industries. The dashed line shows the distribution of defaults for the unconditional bootstrapping without ripple effects. The solid line depicts the portfolio default distribution with single ripple effect. For risk management purposes two values are of special interest: (1) the expected losses which should be covered from loan pricing and provisioning (depicted by the shaded area), and (2) unexpected losses up to 99.9 percentile that should be covered from the regulatory capital (depicted by the dashed shaded area). To see how the latter changes with the ripple effect, we zoom into the tails of this distribution.

Panel (a) of Figure 3.7 shows ripple effect from a single industry default for a diversified portfolio including all 77 manufacturing industries. The dashed line shows the distribution of defaults for the unconditional bootstrapping without ripple effects. The results show 
(a) Overall

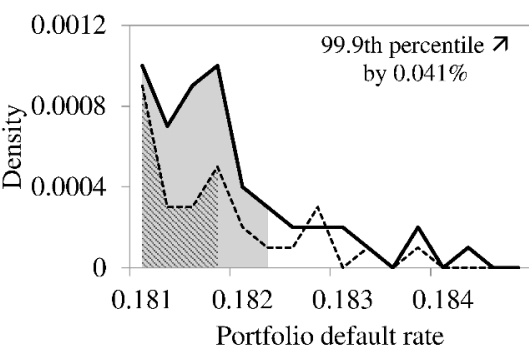

(c) Interconnected industries

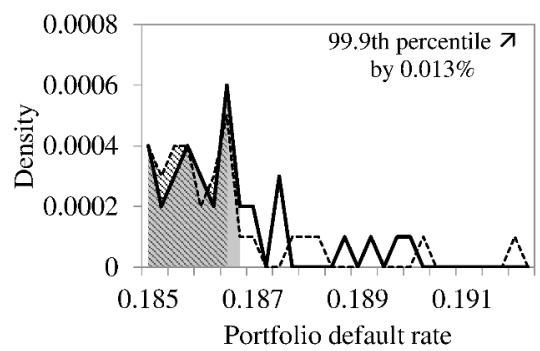

(b) Large industries

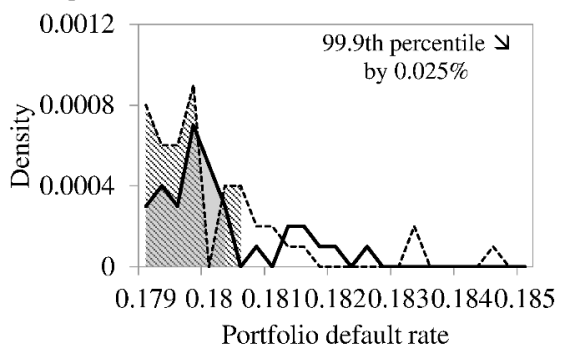

(d) Concentrated industries

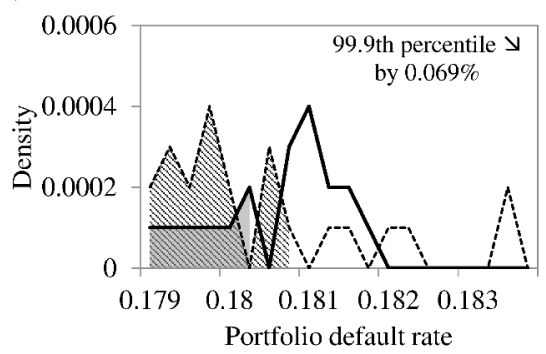

Figure 3.7: Right tails of portfolio default distribution. Ripple effect from a single industry default shifts the density of the portfolio default distribution to the right. It is a consequence of increased expected losses and default correlation. Panel (a) shows ripple effect from a single industry default for a diversified portfolio. Panel (b) shows ripple effect from a single industry default for a portfolio concentrated in large industries. Panel (c) shows ripple effect from a single industry default for a portfolio concentrated in interconnected industries. Panel (d) shows ripple effect from a single industry default for a portfolio concentrated in concentrated industries. The unconditional distribution is given by the dashed line and with ripple effects is given by the solid line. The distributions are bootstrapped from the historical data in the following way: for the unconditional distribution we randomly draw a quarter for each industry and take the number of defaults and total number of firms that were in that industry during that random quarter. For the distribution with ripple effect we first randomly select an industry default from historical data. Then we define the treated industries as the linked industries (suppliers, customers or the same industry). For them we take the number of defaults and total number of firms that occurred in those industries in the following quarter. For the non-treated industries, we repeat the procedure for the unconditional distribution. We repeat that 100.000 times to obtain distribution. The shaded areas depict the 99.9 percentile for the unconditional the loss distribution (dashed shaded area) and for the loss distribution with ripple effect (gray shaded area).

that in a portfolio without ripple effect the 99.9 th percentile of defaults is at $18.17 \%$. In other words, based on this distribution the probability that more than $18.17 \%$ firms will default within the next year is less than $0.1 \%$. This type of information can be used in determining the capital requirements or tranching of a portfolio.

This ripple effect has a substantial implication for the portfolio default distribution as shown in Panel (a) of Figure 3.7. The solid line depicts the portfolio default distribution with a single ripple effect. 
Ripple effect from a single industry default shifts the density of the portfolio default distribution to the right and moves some of the mass to the right tail. It is a consequence of increased expected losses and default correlation. The 99.9th percentile of the default distribution increased from $18.17 \%$ to $18.21 \%$ (which is 4 basis points) after a single industry default. We find that ignoring the ripple effect might lead to an understatement of the portfolio credit risk and thus the required capital.

This non-parametric approach should shed some more light on whether portfolio concentration into large, interconnected and concentrated industries reduces the counterparty risk and ripple effect. Panels (b) to (d) of Figure 3.7 show default distributions for different sub portfolios which are concentrated in the $20 \%$ of larges for (b), most interconnected for (c), and most concentrated industries for (d). Apart from Panel (b), ripple effect is always present, but its magnitude is always smaller than in the diversified portfolio. This gives some scope for risk management in such portfolios.

\subsection{Concluding remarks}

In this paper we draw attention to default risk transmission along the production process. Using a new data set containing information on major defaults on S\&P rated debt, small businesses defaults, production process linkages and industry characteristics, we present evidence that distress in one industry ripples to small businesses in linked industries. Our results show that small businesses in industries exposed to distress through product flow experience significant negative wealth effects and suffer higher default risk. We claim that industries linked either by production process or by product market participate in a ripple effect initiated by one of their counterparties.

We derive our results for U.S. small businesses for which the empirical evidence for default risk transmission is scarce. Importantly, private firms are not less vulnerable to counterparty risk and liquidity shocks than their more researched large-corporate peers. But in general, the measurement of default risk transmission relies on information on individual counterparty exposures, which in small business lending is hindered by the prohibitive cost of information. This paper offers a plausible alternative in which counterparty exposures are modeled as production process linkages. The proposed alternative feeds only on 
public data.

We find evidence that ripple effect is hindered in more concentrated industries. In these industries, the competitive effect plays a dominant role since the firms are able to benefit from counterparty distress. Also, we find that small businesses in large industries (measured by the number of establishments) are subject to lower ripple effects. The damage is therefore contained to a smaller share of the industry that suffers the shock. In other words, relatively fewer firms suffer a hit to their asset value. Moreover, the relationship between interconnectedness (number of bilateral industry connections) and the ripple effect is negative. We observe that wide economic ties offer some diversification benefits. Thus the ripple loses strength as the counterparty risk is slowly diversified away. 


\section{Chapter 4}

\section{Trade credit and firm co-movements}

\subsection{Introduction}

Until recently, economists believed that in the aggregate, idiosyncratic shocks do not matter as they eventually average-out. This view was undermined by work of Long and Plosser (1983), Acemoglu et al. (2012) and Gabaix (2011). For example, Long and Plosser (1983) and Acemoglu et al. (2012) discuss a multi-sector economy, in which a business cycle arises as a result of asymmetric production linkages. In such a multi-sector economy, a shock to a central supplier causes more damage to production than a shock to a peripheral firm, and in aggregate, may not average out. This paper continues this strain of thought, and argues that trade credit amplifies this transmission mechanism. We show that production linkages, along with trade credit, are important for the transmission of idiosyncratic shocks in the economy. We build on the idea that trade credit arises along production linkages, and amplifies idiosyncratic shocks as firms may suffer not only shortage of inputs, but also liquidity.

In the modern economy, suppliers play a dual role: they provide intermediate inputs and extend significant amounts of credit to their customers (Burkart and Ellingsen (2004)). A failure by suppliers often means reduced stock levels and hampered production capacity. During the recent economic slowdown, the fear of disruption to production prompted some firms to give their liquidity-starved suppliers a helping hand. For instance, Bosch, the German car parts and technology firm, 
managed its supply chain risks by offering forward payments and covering costs of raw materials to its suppliers (Bryant (2013)). Wal-Mart followed suit, and offered earlier payments (10-15 days instead of typical 60-90 days) in exchange for a price discount (The Economist (2010)). Wal-Mart's incentives to support its suppliers might have been stronger as the firm is known to use its suppliers as finance providers. Due to the fact that products at the supermarket can be turned into cash at the check-out counter far in advance the supplier needs to be paid, input suppliers to Wal-Mart are effectively also providers of short-term liquidity.

This paper postulates that the use of trade credit in the customersupplier relationship, in general, magnifies the disturbances to a customer's sales. We also argue that in good times when liquidity is abundant, suppliers can insure their customers against liquidity shocks, as proposed in Cuñat (2007). This insurance ultimately stabilizes a customer's sales, but is in place only during booms when suppliers have enough liquidity to support such insurance provision. We formalize this idea in a multi-sector economy of Acemoglu et al. (2012), in which we allow the products delivered on trade credit to have a different productivity to those delivered directly. We derive a testable hypothesis from the augmented Acemoglu et al. (2012) model to see whether this is the case.

Our contribution to the existing literature is threefold. First, this study explores the role of production networks in the propagation of idiosyncratic shocks throughout the economy. We investigate a mechanism described by Acemoglu et al. (2012), in which a shock to one unit in an economy propagates directly onto its production partners and affects their activity. In particular, our paper deals with a fine-grained economy where such a mechanism exists between firms. Here aggregate fluctuations in firms' activity arise from micro-level shocks that strike firms in the production network.

Secondly, the study examines trade credit as a possible amplification mechanism of idiosyncratic shocks. Although the framework of Acemoglu et al. (2012) does not require any market imperfections to generate aggregate fluctuations, we believe that financial constraints as in Kiyotaki and Moore $(1997,2002)$ can stimulate even stronger firm co-movements. Given the role of suppliers as input and trade credit providers, a shock to their production technology alters the availability of inputs and also trade credit.

Lastly, in spite of the wealth of research on cross-sector co-movements, 
there is little empirical evidence at the firm level, in particular on the role of individual firms and their production and trade credit interconnections. Based on a new data set, this study aims to bridge this gap by demonstrating the presence and importance of production and trade credit networks in the propagation of idiosyncratic shocks on a granular (firm) level. The data set covers the years 1980 to 2004, and combines quarterly information on large customers to major U.S. firms from segments information disclosed as part of the Statement of Financial Accounting Standards - SFAS No. 131. This data includes information about the financial position, shocks experienced and sales growth for 2,133 distinct customer-supplier pairs.

To an external observer, co-movements in economic activity seem to originate from large exogenous shocks that affect the entire economy and trigger the business cycle. More recent literature, however, focuses on a second explanation for aggregate fluctuations: the role of disaggregated shocks in aggregate fluctuations. Long and Plosser (1983) derive a theoretical multi-sector model, in which economic activity co-moves as a result of choices of maximizing agents. Shea (2002) and Conley and Dupor (2003) propose sectoral complementarity as the driving force of cross-sector covariance. Also, Horvath (2000) and Holly and Petrella (2012) present evidence that a supplier-customer network propagates sectoral or aggregate shocks through the economy. Importantly, Acemoglu et al. (2012) emphasize that in an economy with asymmetric production linkages, in which one industry plays an important role as a supplier to other industry production process, the diversification argument of Lucas (1977) does not apply. In other words, idiosyncratic shocks do not average-out in the aggregate, but instead cause economic activity to move together across sectors. Yet only Gabaix (2011) and Carvalho and Gabaix (2013) show empirically that a major share of the economic fluctuations can be attributed to firm-level shocks that strike large U.S. firms. The latter studies however neglect the existence of production and trade credit networks.

Imperfections in capital, labor or product markets lay at the root of the third principal explanation for aggregate fluctuations. Important work by Kiyotaki and Moore (1997) discusses a theoretical framework, in which small initial shocks are amplified as a result of credit limits and asset prices. Similarly, Bernanke, Gertler, and Gilchrist (1996) propose that during economic downturns, firms with high agency costs experience greater credit tightening due to creditors' flight to quality. The resulting liquidity shortage is studied also by Cavalcanti (2010) 
who shows that in general larger anti-creditor bias (measured as the fraction of total assets that courts are unable to retrieve from defaulting debtors) causes a sharper decline in credit supply during recession. This pattern is reversed only in economies with exceptionally high anticreditor bias, as local firms are less leveraged. In addition, in a context of a network of interbank exposures, Caballero and Simsek (2013) derive a model, in which a complexity in such networks amplifies the perceived counterparty risk and makes banks reluctant to buy risky assets. This in turn leads to fire sales and a drop in asset prices. However, only Raddatz (2010) discusses the role of trade credit alongside production process linkages in generating and amplifying sectoral co-movements. Our study contributes to this literature by formalizing the role of trade credit in a multi-sector economy of Acemoglu et al. (2012). Additionally, we provide empirical evidence on the most disaggregated level: the firm-level.

Our study is further motivated by the strand of literature proposing firm-level shocks as a micro-foundation of co-movements in economic activity. Seminal work by Gabaix (2011) shows that due to fat-tailed distribution of firm sizes, independent shocks to small firms cannot compensate for shocks to large firms and thus do not average out in the aggregate. This idea is continued in Carvalho and Gabaix (2013) and di Giovanni, Levchenko, and Méjean (2014). The latter analyze a comprehensive data set of French firms and provide evidence on the role of firm-size distribution and production network, but neglect the trade credit channel as an amplification mechanism. Although firmlevel shocks take an important place in economic debate, to date there is no evidence on their role in conjunction with production linkages and trade credit in creating co-movements in the economy.

We provide novel evidence that the use of trade credit between production partners can magnify a shock to a supplier and propagate onto its customers. The disturbance to customer's sales increases with the importance of trade credit linkage. This is especially the case in bad times when firms are short of liquidity and cannot withstand a drop in trade credit provision.

The paper is organized as follows. The next section introduces the multi-sector model with cascading effects, in which productivity shocks to one firm propagate to the rest of the economy. Section 4.3 outlines the empirical design and section 4.5 the data used, in particular the matched data set of the Compustat Segment and Compustat. The empirical results are presented in section 4.5 , which also summarizes 
the implications of idiosyncratic shocks for first-order and higher-order interconnections. Finally, section 4.6 concludes.

\subsection{Theory}

In this section we illustrate how a structural model with explicit production linkages can be used to determine the effects of direct production process linkages and trade credit linkages. As in Acemoglu et al. (2012), we consider a static version of the multi-sector economy of Long and Plosser (1983). The economy is populated by a representative household with given tastes and production possibilities. The household is endowed with one unit of labor, which is supplied inelastically. At the beginning of each period, the household decides about its consumption as well as commodity and labor inputs to various production transformations to be completed this period. Those choices are constrained by the availability of labor and inputs. As we assume the commodities to be perishable, only the amount produced in a given period can be used as an input in the production process in that period. During the period, the production transformation is subject to various exogenous shocks, which alter the production possibilities and ultimately determine the amount of commodities available for consumption or production input.

Each commodity is produced by a competitive firm and can either be directly consumed or used as an input in the production of another commodity. If used as an input, we follow Raddatz (2010) and allow a fraction $\beta$ of this input to be purchased on trade credit. ${ }^{1}$ We deviate from Acemoglu et al. (2012) in that respect. Then, the fraction $(1-\beta)$ is paid up-front or on delivery while payment of the fraction $\beta$ is due at a later date and shows up in the customer's balance sheet as an item in accounts payable.

In particular, $n$ firms buy intermediary inputs from one another and firm $i$ produces quantity $x_{i}$ of commodity $i$ according to a Cobb-Douglas

\footnotetext{
${ }^{1}$ In the Cobb-Douglass representation of production possibilities it is equivalent to consider a proportion of a given input or a proportion of all the inputs to be purchased on trade credit.
} 
technology with constant returns to scale ${ }^{2}$ :

$$
\begin{aligned}
x_{i} & =z_{i}^{\alpha} l_{i}^{\alpha} \prod_{j=1}^{n} x_{i j}^{(1-\alpha)(1-\beta) w_{i j}} x_{i j}^{(1-\alpha) b \beta w_{i j}} \\
& =z_{i}^{\alpha} l_{i}^{\alpha} \prod_{j=1}^{n} x_{i j}^{(1-\beta+b \beta)(1-\alpha) w_{i j}}
\end{aligned}
$$

where $z_{i}=\exp \left(\varepsilon_{i}\right)$ is the firm specific productivity shock distributed independently across firms, $l_{i}$ is the amount of labor hired by firm $i, x_{i j}$ is the amount of commodity $j$ used in the production process of commodity $i$, parameter $\alpha$ is the output elasticity of labor in the economy and parameter $b$ governs the effect of trade credit. If the parameter $b$ assumes a value greater than one, the inputs purchased on trade credit have greater output elasticity than the inputs purchased directly. In the reverse situation, if $b$ assumes a value less than one, the inputs purchased directly have greater productivity. The parameter $w_{i j} \geq 0$ denotes an element in the input-output matrix $W_{n \times n}$ that measures the amount spent on input $j$ per dollar of production of firm $i$. The column sums of $W$ imply the importance of a firm as a supplier to other firms' production processes. At the firm level, the diagonal of $W$ is equal to zeroes since a firm does not deliver to itself. The fact that a firm uses intermediate inputs from other firms is a basis for interconnectedness in this economy. The transmission of idiosyncratic shocks occurs downstream through the input-output matrix from the supplier to its customer.

Let $y$ denote the logarithm of real value added that we call aggregate output for reasons of brevity. In Appendix $\mathrm{C}$ we show that the evolution of aggregate output follows:

$$
y=\mu+u^{\prime} \varepsilon
$$

where $\mu$ is a constant that depends on models parameters only, $\varepsilon$ is a vector of firm specific shocks and $u$ is a vector that governs the transmission of idiosyncratic shocks in the economy. With $\mathbf{1}$ defined as a

\footnotetext{
${ }^{2}$ From constant returns to scale we have that: $\sum_{j} w_{i j}=\frac{1}{1-\beta+b \beta}$
} 
column vector of ones, we derive the vector $u$ as:

$$
\begin{aligned}
u & =\frac{\alpha}{n}\left[I-(1-\alpha)(1-\beta+b \beta) W^{\prime}\right]^{-1} \mathbf{1} \\
\text { or } \quad u & =\frac{\alpha}{n}\left[I-(1-\alpha)(1+\eta \beta) W^{\prime}\right]^{-1} \mathbf{1} \\
\text { where } \quad \eta=b-1 &
\end{aligned}
$$

Equation (4.2) shows that the fluctuations in aggregate output are a sum of idiosyncratic shocks to firms in the economy with coefficients given by the elements of the $u$ vector. In other words, fluctuations in aggregate output originate from disturbances to a firm's production possibilities. Those disturbances are then weighted by the importance of production and trade credit linkages. Importantly, the parameter $\eta$ corresponds to the importance of trade credit linkage. If $\eta$ takes a value greater than zero it amplifies the transmission mechanism that occurs due to direct production process linkage. Values lower than zero decrease this mechanism. If trade credit has no effect on the transmission of idiosyncratic shocks between firms, the parameter $\eta$ takes a value of zero and the above equation simplifies to the influence vector of Acemoglu et al. (2012) given by:

$$
v=\frac{\alpha}{n}\left[I-(1-\alpha) W^{\prime}\right]^{-1} \mathbf{1}
$$

where the aggregate fluctuations arise as a consequence of idiosyncratic shocks and the firms' production network in the economy only.

Similarly as in Raddatz (2010), the vector $u$ reflects both the production network and the trade credit channel in transmitting the idiosyncratic shocks. In particular, by taking a first order Taylor approximation of $u$ around $\eta=0$, it follows that:

$$
\begin{aligned}
u & \approx \frac{\alpha}{n}\left[I-(1-\alpha) W^{\prime}\right]^{-1} \mathbf{1} \\
& +\eta \frac{\alpha}{n}\left[I-(1-\alpha) W^{\prime}\right]^{-1}(1-\alpha) \beta W^{\prime}\left[I-(1-\alpha) W^{\prime}\right]^{-1} \mathbf{1} \\
& =v+\eta\left[I-(1-\alpha) W^{\prime}\right]^{-1}(1-\alpha) \beta W^{\prime} v .
\end{aligned}
$$

It can be seen that elements of the $u$ vector depend on the direct production network linkages (first term) and to some degree on the trade credit channel (second term). ${ }^{3}$ Elements of the $u$ vector can be considered as weights. Those weights if applied to firm-level shocks result

\footnotetext{
${ }^{3}$ For derivation please refer to Appendix D
} 
in aggregate fluctuations. The greater the importance of a firm as an input supplier, the greater the term $v$ and the greater the weight of its shock on its downstream customers. Also, with positive values of $\eta$, the larger the share of inputs provided on trade credit $(\beta)$, the greater the weight applied to a supplier's shock.

For a single customer, equation (4.2) and (4.5) imply that customers' activity is subject to its suppliers' economic conditions. And the more strategic is the supplier, i.e. by delivering a large share of inputs (large $w_{i j}$ ) or of trade credit (large $\beta$ ), the greater is the customer's exposure to a supplier's shocks. In Appendix 3 we show that on a firm level it holds that::

$$
y_{i}=\mu_{i}+\sum_{j=1}^{n} D_{j i} \varepsilon_{j}+\eta \sum_{j=1}^{n}\left[\left(1-(1-\alpha) W^{\prime}\right)^{-1}(1-\alpha) \beta W^{\prime} D\right]_{j i} \varepsilon_{j}
$$

where $\quad D \equiv \frac{\alpha}{n}\left[I-(1-\alpha) W^{\prime}\right]^{-1}$.

In the economy described above, we assume the household has a Cobb-Douglass utility function over $n$ distinct commodities:

$$
u\left(c_{1}, c_{2}, \ldots, c_{N}\right)=\prod_{i=1}^{n}\left(c_{i}\right)^{1 / n}
$$

where $c_{i}$ is the consumption of $i$ 's commodity.

\subsection{Empirical approach}

Our main objective is to determine if disturbances in a customer's sales can be attributed to trade credit exposures that occur along production linkages. To this end, we identify idiosyncratic shocks $\varepsilon$ by means of a strategy proposed by Gabaix (2011). Manski (1993) notices a reflection problem. This boils down to the idea that firms' activity might be volatile due to aggregate shocks, but not necessarily vice versa. To address this reflection problem, we use various measures for the idiosyncratic shocks. We begin with the following representation of firm activity:

$$
y_{i} \equiv \ln \left(\text { sales }_{i}\right) .
$$

We motivate this choice by the fact that trade credit is measured as a proportion of sales supplied with a deferred payment. As the 
trade credit channel is central for our analysis, we refrain from other measures, such as value added per worker (see Gabaix (2011)), total factor productivity (see Carvalho and Gabaix (2013)) or employment (see Moscarini and Postel-Vinay (2012)). Also di Giovanni, Levchenko, and Méjean (2014) look exclusively into the development of sales.

We quantify $\varepsilon_{i}$ in a manner similar to Gabaix (2011), that is we set the idiosyncratic shock to be a deviation from a certain benchmark. Similar to Gabaix (2011), we set this benchmark to be equal to average sales in the economy and denote it by $\bar{y}_{E}$. In particular, this benchmark is computed as an average $\ln ($ sales) of all firms in Compustat database. The firm-level shock is then given by a difference between the business' sales and the average sales in the economy:

$$
\hat{\varepsilon}_{i}=y_{i}-\bar{y}_{E} \text {. }
$$

An alternative specification is to measure the deviations relative to an industry or region benchmark where the industry benchmark is given by the average sales of firms in a particular industry. We use the six digit NAICS classification to define an industry. The region benchmark is given by an average of the sales of firms in a region where the region is defined by the zip code of each firm's headquarters. Those specifications make the assumption that the firms respond to the common factors with the same sensitivity.

Due to large firms having the value of $y_{i}$ persistently above the benchmark, we focus instead on the change in a firm's activity, since this is more appropriate for giving insights into a firm's condition. In particular, if a firm grows at a rate higher than the growth rate of its benchmark, it can give an additional boost to its customers by delivering more inputs or trade credit. That is why we follow the literature (Gabaix (2011), di Giovanni, Levchenko, and Méjean (2014), etc.) and look into the growth rate of firm's activity and in particular into growth rate of sales. So, let the growth rate of sales be given by $g_{i}=\Delta y_{i}$ which is the difference in log sales from one year to the other and $\hat{e}_{i}=\Delta \hat{\varepsilon}_{i}$ which is the change in log sales from one year to the other relative to the change in the benchmark. ${ }^{4}$ To test the hypothesis that trade credit on a firm-level amplifies idiosyncratic shocks to suppliers and transmits them downstream onto production partners, we take the first difference in equation (4.6):

$$
g_{i}=\underbrace{\sum_{j=1}^{n} D_{j i} \hat{e}_{j}}_{\text {production process exposures }}+\eta \underbrace{\sum_{j=1}^{n}\left[\left(1-(1-\alpha) W^{\prime}\right)^{-1}(1-\alpha) \beta W^{\prime} D\right]_{j i}}_{\text {trade credit exposures }} \hat{e}_{j} .
$$

\footnotetext{
${ }^{4}$ Note that $\hat{e}_{i}=\Delta \hat{\varepsilon}_{i}$ is also equivalent to $\hat{e}_{i}=\Delta g_{i}-\Delta g_{E}$.
} 
The second term, which we call production process exposures, depicts the relationship between a customer's sales growth and the production linkages in the absence of trade credit linkages, or if trade credit does not matter for transmission of idiosyncratic shocks. It is a weighted sum of firm-level suppliers' shocks, where the weights depend on the relative importance of those suppliers in customer's production. The third term, which we call trade credit exposures, is a weighted sum of firm-level suppliers' shocks with weights determined by both suppliers' importance in delivering inputs and their position as trade credit providers.

In that third term, parameter $\eta$ indicates the importance of the trade credit channel in the transmission of firm-level shocks. Positive values of $\eta$ amplify the disturbance to the production process while negative values dampen that effect. If $\eta=0$ the trade credit channel is irrelevant for the transmission of idiosyncratic shocks between firms. We test our hypothesis about the role of trade credit in transmitting idiosyncratic shocks by looking if the parameter $\eta$ is equal to zero. In general, we expected the estimate of $\eta$ to be positively and significantly associated with customers' sales growth. During booms, however, we expect this relationship to be negative as trade credit can serve as insurance from liquidity shocks to customers.

To this end we estimate variants of the following specification:

$$
g_{i}=\phi \sum_{j=1}^{n} D_{j i} \hat{e}_{j}+\eta \sum_{j=1}^{n}\left[\left(1-(1-\alpha) W^{\prime}\right)^{-1}(1-\alpha) \beta W^{\prime} D\right]_{j i} \hat{e}_{j}+\xi_{i} .
$$

From the theoretical model we expect the estimate of parameter $\phi$ to be equal to one.

\subsection{Data}

At the heart of our data is a list of all customer-supplier linkages. Under the Statement of Financial Accounting Standards - SFAS No. 131 a firm needs to disclose certain information on operating segments. In particular, firms are required to reveal the identity of major customers that correspond to $10 \%$ or more of its sales. The customer-supplier linkages are collected from the Compustat Segments from 1980 to 2004. Compustat Segments reports only the name of the major customer and the dollar amount of sales to this customer. In order to match the 


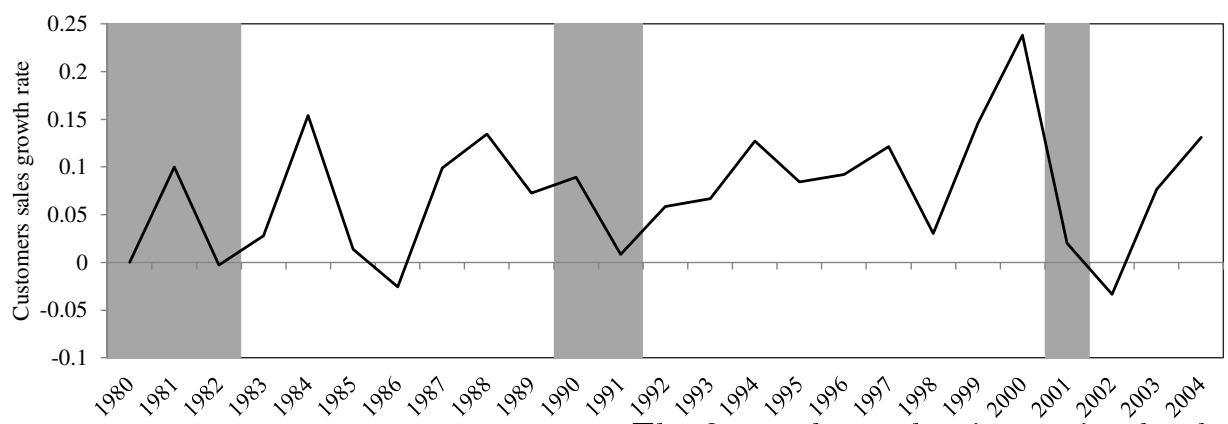

Figure 4.1: Customers sales growth rate. The figure shows the time series development of the average growth rate of sales among the customers.

supplier to financial information on its customers we use the sample provided by Cohen and Frazzini (2008). The sample assigns the Compustat Segments customers to CRSP's permno. We use this established connection to match the customer-supplier linkages contained in Compustat Segments to CRSP-Compustat's balance sheet information.

We base our analysis on all the customer-supplier pairs established by Cohen and Frazzini (2008) with a match to Compustat balance sheet information and non-missing values of sale in two consecutive years. The final set contains 2,730 unique customer-year observations. Each of these observations is connected on average to 2.4 suppliers with a total of 6,558 unique firm-year customer-supplier relationships that represent 2,133 distinct customer-supplier pairs over the years 1980 to 2004.

Table 4.1 presents the descriptive statistics of our sample. The customers reported in Panel A tend to be larger than the suppliers in Panel B. This discrepancy is partially due to the way the data has been constructed. The customers reported in Compustat Segments, and therefore in the Cohen and Frazzini (2008) sample, are those that correspond to at least $10 \%$ of sales. Those firms are inclined to be larger, with assets on average almost 23 times higher and sales 16 times higher than the sample of suppliers. During the entire sample period, both customers and suppliers experience, on average, a positive sales growth rate $(g)$. The average customers' sales growth is illustrated in Figure 4.1. For most of the time it stays positive with short episodes of negative growth in 1982, 1986 and 2002.

The labor income share denoted by $\alpha$ is assumed to be constant over the whole economy and takes value of 0.61 . We compute it from the OECD data on Unit Labor Costs as the average of Labor Income Share (Real ULC) over the years when the statistic is available, that is from 
1995 to 2004 . Next, the parameter $\left(w_{i j}\right)$ is said to capture the amount spent on input $j$ per dollar of production of firm $i$. On a firm-level we approximate it by the ratio of sales from supplier (firm $j$ ) to customer (firm $i$ ) over the customer's cost of goods sold (Compustat item cogs). It represents the amount the customer $i$ spent on inputs from supplier $j$ per dollar amount of the cost of its production. On average, about $7.10 \%$ of customer's inputs come from one of its suppliers. Next, similarly to Raddatz (2010), we measure the share of trade credit received by customer $(\beta)$ as the ratio of its accounts payable (Compustat item ap) over its cost of goods sold (Compustat item cogs). It depicts the proportion of purchased inputs with deferred payment and customary reflects the share of goods that the customer purchased in trade credit. Due to data availability, we are not able to distinguish how much of the trade credit comes from which supplier. To this end we assume this proportion to be equal across all its relationships with suppliers. In our sample, customers buy about $46.20 \%$ of its inputs on trade credit. This is a relatively high proportion which can be the result of the construction of the customers' sample. It includes larger firms which may execute some form of market power and demand better delivery conditions from their suppliers. As a comparison, Raddatz (2010) reports an average of $13.00 \%$ of inputs that were financed with trade credit for a universe of US firms in Compustat over a similar time period.

We identify the shocks $(\hat{e})$ to suppliers as a deviation from a benchmark. The benchmark is given by an average sales growth among a group of firms, to which the supplier belongs. We take the Compustat universe of firms to compute the economy sales growth $\left(\bar{g}_{E}\right)$ as the average growth among all the Compustat firms. Next, we categorize firms into industries based on the four digit SIC code to compute the industry benchmark as an average for sales growth among firms in the same industry. We repeat that exercise and compute the state benchmark as an average for sales growth among firms in the same U.S. state and the county benchmark as an average for sales growth among all firms operating in the same county.

\subsection{Application and results}

In this section, particular interest is paid to the relevance of trade credit linkages along the production process linkages in the propagation of shocks from suppliers to customers. According to our model in 
Table 4.1

\section{Descriptive statistics}

The sample runs from 1980 to 2004. It covers all the customer-supplier pairs established by Cohen and Frazzini (2008) with a match to Compustat balance sheet information and non-missing values of sale in two consecutive years. Panel A shows the descriptive statistics for the sample of customers. Panel B shows the descriptive statistics for the sample of suppliers.

\begin{tabular}{|c|c|c|c|c|c|}
\hline & $\mathrm{N}$ & Mean & SD & Min & $\operatorname{Max}$ \\
\hline \multicolumn{6}{|l|}{ Panel A: Customers } \\
\hline Assets [ $\$$ billions] & 2,730 & $25,952.270$ & $82,226.300$ & 0.719 & $1,484,101.000$ \\
\hline EBIT [ $\$$ billions] & 2,680 & $1,724.820$ & $3,757.393$ & $-10,537.000$ & $52,205.000$ \\
\hline Sales [ $\$$ billions] & 2,730 & $15,295.560$ & $27,421.090$ & 0.126 & $286,103.000$ \\
\hline Sales growth rate $(g)$ & 2,730 & 0.080 & 0.257 & -3.417 & 2.606 \\
\hline$w_{i j}$ & 2,310 & 0.071 & 0.567 & 0.000 & 17.321 \\
\hline Share of trade credit received $\beta$ & 2,691 & 0.462 & 2.246 & 0.000 & 39.026 \\
\hline \multicolumn{6}{|c|}{ Production process exposures (second term in equation (4.11)) computed relative to: } \\
\hline - economy benchmark & 2,730 & -0.001 & 0.125 & -5.802 & 1.162 \\
\hline - industry benchmark & 2,730 & 0.135 & 7.144 & -2.512 & 373.274 \\
\hline - state benchmark & 2,730 & -0.02 & 1.012 & -52.771 & 0.948 \\
\hline - county benchmark & 2,730 & 1.242 & 64.974 & -3.173 & 3394.861 \\
\hline \multicolumn{6}{|c|}{ Trade credit exposures (third term in equation (4.11)) computed relative to: } \\
\hline - economy benchmark & 2,730 & -0.003 & 0.243 & -12.37 & 1.137 \\
\hline - industry benchmark & 2,730 & 0.29 & 15.23 & -2.484 & 795.758 \\
\hline - state benchmark & 2,730 & 0 & 0.108 & -4.803 & 1.162 \\
\hline - county benchmark & 2,730 & 0.112 & 5.914 & -2.061 & 308.976 \\
\hline \multicolumn{6}{|l|}{ Panel B:Suppliers } \\
\hline Assets [ $\$$ billions] & 4,613 & $1,191.835$ & $3,946.029$ & 0.491 & $73,634.900$ \\
\hline EBIT [ $\$$ billions] & 4,532 & 80.432 & 403.699 & $-2,285.963$ & $1,0504.000$ \\
\hline Sales [ $\$$ billions] & 4,509 & 907.607 & $3,007.936$ & 0.004 & $47,180.970$ \\
\hline Sales growth rate $(g)$ & 4,613 & 0.094 & 0.426 & -2.994 & 4.057 \\
\hline \multicolumn{6}{|l|}{ Shock $(\hat{e})$ computed with: } \\
\hline - economy benchmark & 4,613 & -0.007 & 0.421 & -3.172 & 4.067 \\
\hline - industry benchmark & 4,613 & -0.008 & 0.399 & -3.038 & 3.873 \\
\hline - state benchmark & 4,613 & -0.006 & 0.416 & -3.246 & 3.874 \\
\hline - county benchmark & 4,613 & -0.004 & 0.421 & -3.172 & 4.067 \\
\hline
\end{tabular}

section 4.2, a shock to a supplier can be transmitted either in the form of a failure to deliver intermediate inputs, and therefore disrupting customer's production process, or through the trade credit channel that disrupts a customer's liquidity.

Before we delve into the role of trade credit as a transmission mechanism, we examine in Table 4.2 the correlations between customer and supplier sales growth, and the benchmarks. The correlations are computed from yearly observations pooled across all the customer and supplier firms. At the bottom of column (2) we report the correlations between supplier sales growth and the shocks to customer sales growth using different benchmarks. The high correlation indicates that there is a considerable commonality between disturbance to customer sales growth and their suppliers' sales growth. High deviations of customer sales growth are associated with high supplier sales growth. Also, customer sales growth tends to be correlated with shocks to their suppliers. 
Table 4.2

\section{Correlation between customer sales growth and supplier sales growth}

Pairwise correlation coefficients are calculated over yearly observations pooled across all the customer and supplier firms. The sales growth among customers is denoted by $g_{C}$ and among supplier by $g_{S}$. The economy benchmark is denoted by $\bar{g}_{E}$, the industry benchmark by $\bar{g}_{I}$, the state benchmark by $\bar{g}_{S}$, and the county benchmark by $\bar{g}_{C}$. The shock calculated relative to the economy benchmark is denoted by $\hat{e}_{E}$, relative to the industry benchmark by $\hat{e}_{I}$, relative to the state benchmark by $\hat{e}_{S}$, relative to the county benchmark by $\hat{e}_{C}$.

\begin{tabular}{lrrrrrrrrrr}
\hline & $s_{C}$ & $s_{S}$ & $\bar{g}_{E}$ & $\bar{g}_{I}$ & $\bar{g}_{S}$ & $\bar{g}_{C}$ & $\hat{e}_{E}$ & $\hat{e}_{I}$ & $\hat{e}_{S}$ & $\hat{e}_{C}$ \\
\hline & $(1)$ & $(2)$ & $(3)$ & $(4)$ & $(5)$ & $(6)$ & $(7)$ & $(8)$ & $(9)$ & $(10)$ \\
\hline$g_{C}$ & 1.000 & & & & & & & & \\
$g_{S}$ & 0.195 & 1.000 & & & & & & & \\
$\bar{g}_{E}$ & 0.285 & 0.157 & 1.000 & & & & & & \\
$\bar{g}_{I}$ & 0.259 & 0.353 & 0.416 & 1.000 & & & & & \\
$\bar{g}_{S}$ & 0.272 & 0.212 & 0.729 & 0.407 & 1.000 & & & & \\
$\bar{g}_{C}$ & 0.172 & 0.172 & 0.603 & 0.288 & 0.469 & 1.000 & & & \\
$\hat{e}_{E}$ & 0.159 & 0.991 & 0.020 & 0.300 & 0.114 & 0.092 & 1.000 & & & \\
$\hat{e}_{I}$ & 0.092 & 0.910 & -0.015 & -0.066 & 0.046 & 0.059 & 0.924 & 1.000 & & \\
$\hat{e}_{S}$ & 0.146 & 0.981 & 0.014 & 0.279 & 0.016 & 0.084 & 0.991 & 0.922 & 1.000 & \\
$\hat{e}_{C}$ & 0.160 & 0.974 & 0.023 & 0.293 & 0.110 & -0.056 & 0.983 & 0.909 & 0.975 & 1.000 \\
\hline
\end{tabular}

The time series evolution of the economy, industry, state and county benchmark is illustrated in Figure 4.2. Their behavior is related to the average sales growth rate among suppliers and their shock, which we approximate by the deviation from the benchmark. In general, their behavior is closely related, and both values co-move together. For example, during the NBER recessions, illustrated by the shaded areas, both the benchmark and the average behavior of suppliers tend to drop considerably.

Whether those shocks to suppliers are transmitted through the production network, and which part of the production network plays a crucial role, is answered in Table 4.3. We report coefficients on the production process term $(\phi)$ and on the credit linkage $(\eta)$. We postulate that the use of credit in the customer-supplier relationship magnifies the disturbances to a customer's sales. As described in section 4.2, we are able to test this hypothesis by estimating the coefficients in equation (4.11). The estimated relationship between the production linkage $(\phi)$ and the credit linkage $(\eta)$ is expected to be positive and significant as the change to customer's sales should be greater with a greater shock to its crucial suppliers of inputs and of trade credit. Table 4.3 shows that apart from the production linkage, the credit linkage is positively and significantly related to customers' sales growth (which is given by the positive and significant coefficient on trade credit exposures $\eta$ ). Depending on the specification, a one standard deviation increase in the 
a) Economy benchmark

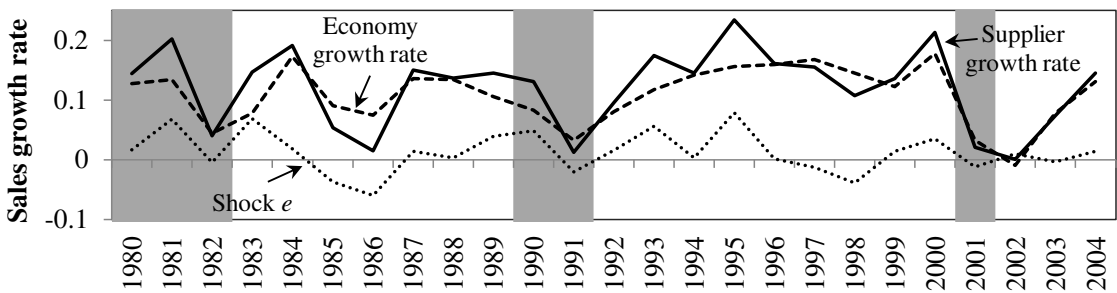

b) Industry benchmark

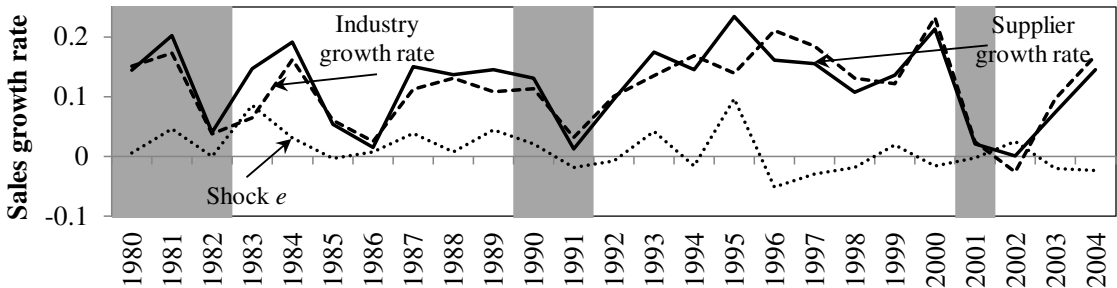

c) State benchmark

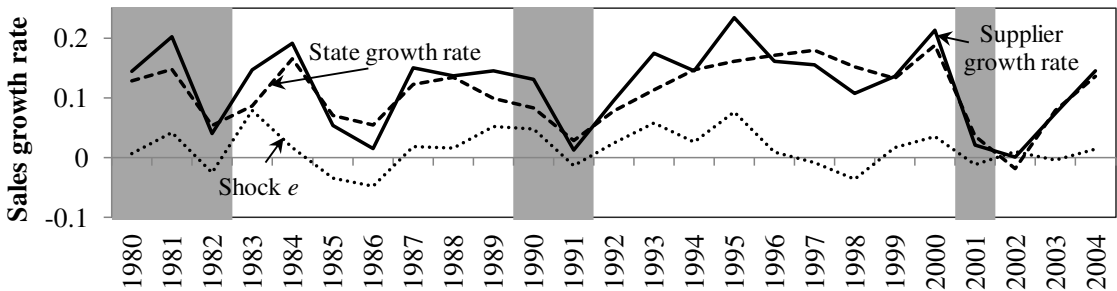

d) County benchmark

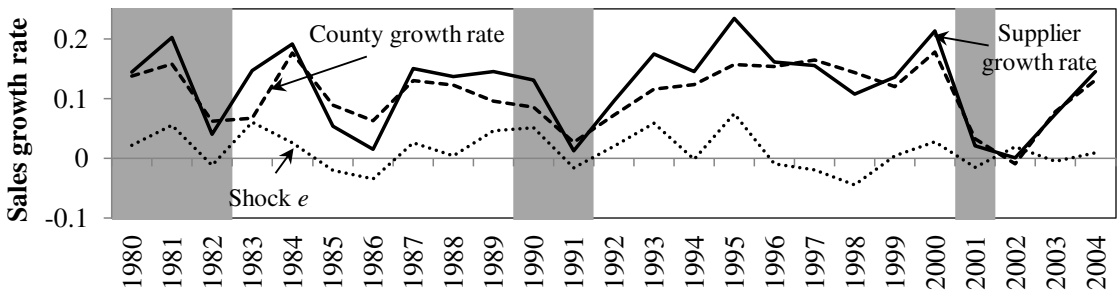

Figure 4.2: Suppliers sales growth rate and the benchmark. The figure shows the time series developments of average growth rate of sales among suppliers. It is benchmarked against the average growth rate in the economy (Panel a), in the industry (Panel b), in the state (Panel c), in the county (Panel d).

use of trade credit $(\beta)$ increases the customer's sales growth by 3.59$4.27 \%$. The effect is also economically significant, with a one standard deviation increase in a shock to one supplier increasing a customer's sales growth by $0.64-0.79 \%$, depending on the benchmark used in the 
Table 4.3

\section{Trade credit linkages and sales growth}

Trade credit channel amplifies disturbances to sales growth. The Table shows coefficient estimates of the equation (4.11), in which the dependent variable is the sales growth of a firm. The figures in square brackets represent the economic effect of the production and credit linkages, which is a change in a customer's sales growth to a one standard deviation increase in the shock to a single supplier. The sample runs from 1980 to 2004. All regressions include a constant. Significance is denoted by $*$ at the $90 \%$ level, $* *$ at the $95 \%$ level and $* * *$ at $99 \%$ level. Standard errors in parenthesis.

\begin{tabular}{|c|c|c|c|c|}
\hline \multicolumn{5}{|c|}{ Sales growth } \\
\hline & \multicolumn{4}{|c|}{ Benchmark } \\
\hline & $\begin{array}{c}\text { Economy } \\
\text { (1) }\end{array}$ & $\begin{array}{c}\text { Industry } \\
(2)\end{array}$ & $\begin{array}{c}\text { State } \\
(3)\end{array}$ & $\begin{array}{c}\text { County } \\
(4)\end{array}$ \\
\hline \multicolumn{5}{|l|}{$\overline{\text { Panel A: Basic results }}$} \\
\hline \multirow[t]{3}{*}{ Production linkages $(\phi)$} & $1.138 * * *$ & $1.044 * * *$ & $1.231 * * *$ & $1.166 * * *$ \\
\hline & $(0.081)$ & $(0.084)$ & $(0.085)$ & $(0.082)$ \\
\hline & [0.479] & {$[0.417]$} & {$[0.512]$} & [0.491] \\
\hline \multirow[t]{3}{*}{ Credit linkages $(\eta)$} & $0.018^{* * *}$ & $0.016 * * *$ & $0.019 * * *$ & $0.018 * * *$ \\
\hline & $(0.001)$ & $(0.001)$ & $(0.001)$ & $(0.002)$ \\
\hline & {$[0.008]$} & {$[0.006]$} & {$[0.008]$} & {$[0.008]$} \\
\hline Firm F.E. & No & No & No & No \\
\hline Year F.E. & No & No & No & No \\
\hline$N$ & 2,730 & 2,730 & 2,730 & 2,730 \\
\hline$R^{2}$ & 0.066 & 0.053 & 0.070 & 0.068 \\
\hline \multicolumn{5}{|c|}{ Panel B: Fixed effects models } \\
\hline \multirow[t]{3}{*}{ Production linkages $(\phi)$} & $1.162^{* * *}$ & $0.864 * * *$ & $1.272^{* * *}$ & $1.185^{* * *}$ \\
\hline & $(0.088)$ & $(0.083)$ & $(0.092)$ & $(0.090)$ \\
\hline & [0.489] & {$[0.345]$} & {$[0.529]$} & {$[0.499]$} \\
\hline \multirow[t]{3}{*}{ Credit linkages $(\eta)$} & $0.018^{* * *}$ & $0.013^{* * *}$ & $0.02^{* * *}$ & $0.018^{* * *}$ \\
\hline & $(0.001)$ & $(0.001)$ & $(0.001)$ & $(0.002)$ \\
\hline & {$[0.008]$} & {$[0.005]$} & {$[0.008]$} & {$[0.008]$} \\
\hline Firm F.E. & Yes & Yes & Yes & Yes \\
\hline Year F.E. & Yes & Yes & Yes & Yes \\
\hline$N$ & 2,730 & 2,730 & 2,730 & 2,730 \\
\hline$R^{2}$ & 0.164 & 0.137 & 0.169 & 0.164 \\
\hline
\end{tabular}

Panel A of Table 4.3.

The positive and significant coefficients on the production exposures and trade credit exposures imply that a shock to downstream suppliers is transmitted through two channels: (1) production channel as a disturbance in input delivery and (2) trade credit channel as a disruption in the use of trade credit. The growth in customers' sales is therefore subject to the state of their suppliers that are vital with respect to delivery of inputs and trade credit. The basic result is robust to alternative benchmarks and to inclusion of firm and annual fixed effects.

Note that our matrix of linkages is not exhaustive, and we are missing the customer-supplier linkages that do not pass the $10 \%$ threshold to be reported in the Compustat Segments database. However, we believe that it would be acceptable for those connections to be approximated by the industry, state or county benchmark. In turn, this leaves those 
connections with no impact on the analysis as their shocks are equal to zero.

In the last step, we look at timing of the trade credit channel in transmitting shocks from downstream suppliers to upstream customers. To grasp how the trade credit channel can change with liquidity in the economy, we distinguish between booms and recessions according to the NBER business cycle reference dates. Studies like Gao (2014) show that in a tight network of customer-supplier relationships, a liquidity shock to one firm triggers a flow of liquidity from other parts of the network. An example we mentioned earlier is Bosch that supported its liquidity starved suppliers by offering them forward payments and reimbursement of raw materials. Such behavior by firms can dampen shocks to any of the firms in such liquidity rich networks. On the other hand, if firms depend on the liquidity provided by their production partners, a small shock to one firm in the network can spillover onto their affiliates and cause a larger disruption to the production process than the initial shock. Table 4.4 provides evidence of such supporting behavior during booms (Panel A) when networks are abundant in liquidity. It is given by the negative and significant coefficient on the trade credit term $(\eta)$ and means that during good times trade credit works as a stabilizer of firms' sales growth. This pattern, however, is reversed during recessions (Panel B). At those times, firms are not able to lend a helping hand to their production partners and the existence of trade credit linkage increases the damage to production processes.

\subsection{Concluding remarks and discussion}

This paper provides a framework, in which a transmission of idiosyncratic (firm-level) shocks across firms in the economy occurs along production linkages and trade credit connections. We build on the idea that trade credit arises along production linkages and amplifies idiosyncratic shock as firms may be exposed to not only a shortage of inputs but also liquidity.

We provide novel evidence that use of trade credit between production partners can exacerbate a shock to suppliers and spill-over to their customers. The wider and more important the trade credit linkage, the higher the disturbance to a customer's sales. We find that a customer's sales growth rate changes with shocks to important input suppliers and significant trade credit providers. Also, although the trade credit chan- 
Table 4.4

\section{Trade credit linkages and sales growth - different phases of business cycle}

Trade credit channel amplifies disturbances to sales growth during bad times but dampens during good times. The Table shows coefficient estimates of the equation (4.11), in which the dependent variable is the sales growth of a firm. The sample runs from 1980 to 2004 . Recession years are taken from the NBER business cycle reference dates and includes years: 1980, 1981, 1982, 1990, 1991 and 2001. The boom years are those remaining. All regressions include a constant. Significance is denoted by * at the $90 \%$ level, $* *$ at the $95 \%$ level and $* * *$ at $99 \%$ level. Standard errors in parenthesis.

\begin{tabular}{|c|c|c|c|c|}
\hline \multicolumn{5}{|c|}{ Sales growth } \\
\hline & \multicolumn{4}{|c|}{ Benchmark } \\
\hline & $\begin{array}{c}\text { Economy } \\
(1)\end{array}$ & $\begin{array}{c}\text { Industry } \\
(2)\end{array}$ & $\begin{array}{c}\text { State } \\
(3)\end{array}$ & $\begin{array}{c}\text { County } \\
(4)\end{array}$ \\
\hline \multicolumn{5}{|l|}{ Panel A: Boom } \\
\hline Production linkages $(\phi)$ & $\begin{array}{c}1.312^{* * *} \\
(0.090)\end{array}$ & $\begin{array}{l}1.467^{* * *} \\
(0.102)\end{array}$ & $\begin{array}{l}1.319^{* * *} \\
(0.091)\end{array}$ & $\begin{array}{c}1.312^{* * *} \\
(0.089)\end{array}$ \\
\hline Credit linkages $(\eta)$ & $\begin{array}{l}-0.300 * * * \\
(0.094)\end{array}$ & $\begin{array}{l}-0.250^{* *} \\
(0.101)\end{array}$ & $\begin{array}{l}-0.310^{* * * *} \\
(0.096)\end{array}$ & $\begin{array}{l}-0.524^{* * *} \\
(0.195)\end{array}$ \\
\hline Firm F.E. & No & No & No & No \\
\hline Year F.E. & No & No & No & No \\
\hline$N$ & 2,236 & 2,236 & 2,236 & 2,236 \\
\hline$R^{2}$ & 0.087 & 0.086 & 0.086 & 0.088 \\
\hline \multicolumn{5}{|l|}{ Panel B: Recession } \\
\hline Production linkages $(\phi)$ & $\begin{array}{l}0.745^{* * *} \\
(0.237)\end{array}$ & $\begin{array}{c}0.304^{*} \\
(0.180)\end{array}$ & $\begin{array}{l}1.340^{* * * *} \\
(0.318)\end{array}$ & $\begin{array}{c}0.724 \text { *** } \\
(0.234)\end{array}$ \\
\hline Credit linkages $(\eta)$ & $\begin{array}{l}0.012^{* * *} \\
(0.004)\end{array}$ & $\begin{array}{c}0.005^{*} \\
(0.003)\end{array}$ & $\begin{array}{l}0.021^{* * * *} \\
(0.005)\end{array}$ & $\begin{array}{l}0.011^{* * *} \\
(0.004)\end{array}$ \\
\hline Firm F.E. & No & No & No & No \\
\hline Year F.E. & No & No & No & No \\
\hline$N$ & 494 & 494 & 494 & 494 \\
\hline$R^{2}$ & 0.016 & 0.002 & 0.031 & 0.015 \\
\hline
\end{tabular}

nel can serve as a stabilizer of customer's sales in good times, this is does not occur in bad times when firms are short of liquidity and so are unable to withstand a drop in trade credit provision. 


\section{Chapter 5}

\section{Conclusions and discussion}

This dissertation analyzes the issues related to co-movements in credit risk by firms and industries among production partners that use trade credit. In particular, we look at this from three different perspectives: asymptotic single factor model (chapter two), empirical difference-indifference approach (chapter three) and a multi-sector economy model (chapter four). In all three we discuss the existence and sources of co-movements in firms' activity and credit risk. Below we outline the general findings of this dissertation and their application.

\section{Credit risk and small businesses}

Small businesses are not as well researched as their larger counterparts. The main obstacle to researching private firms is the absence of publicly available financial statements, as well as the lack of market trading. In chapter two we propose a technique to estimate the dependency of a portfolio on small business. We find that sensitivity to common risk factors is very low and small businesses mostly face idiosyncratic risk, for example related to their location or manager characteristics.

The low sensitivity to common risk factor translates into low asset correlation. Portfolios of loans with those characteristics have a low level of unexpected losses. Banks cover these from the required capital. If pricing and provisioning of those loans is done properly, banks should be required to hold only small amount of capital against those loans. However, we find that Basel II overestimates the required capital for portfolios of loans to small businesses, with the most creditworthy small firms being required the highest capital charges relatively to their riskiness. 
Additionally, in chapter three, we approach the question of default correlation from the banks' perspective. For instance, we identify signals that are easily and publicly available (default on S\&P rated debt) that banks should be concerned with as they are followed by default clustering. Additionally, we look at how default correlation differs with changing compositions of bank loan portfolios. We find evidence that default correlations are lower in concentrated and in large industries.

\section{Correlations and production linkages}

In chapter three we demonstrate that default correlation takes place prior to bankruptcy, and can affect not only direct creditors, but also small firms that operate in industries linked by the production process. So far, the existing literature on default correlation focused on the more researched public firms. The question of failure dependencies for small private firms, however, remains an open one. It is especial interesting since loans to small private firms constitute a quarter of all commercial and industrial lending.

Importantly, we show evidence of default correlation for small businesses. The existing research has not equipped banks with tools to measure the counterparty risk in such portfolios. One problem with measuring counterparty risk in portfolios of loans to small private firms is the lack (or the prohibitive cost) of data about individual counterparty exposure. Instead, we propose to use the input-output tables (publicly available information) which indicates which industry produces goods used as production inputs in another industry. Ultimately, we argue that industry production linkages are a valid method for determining a proxy for counterparty exposure in portfolios with limited information, such as portfolios small business loans.

In chapter four, we show that, in general, trade credit that accompanies production linkages can aggravate a shock to the supplier, but also the customer as the shock is transmitted downstream. The more trade credit between production partners is widely and deeply used, the higher the disturbance to a customer's sales. This pattern is reversed in good times when trade credit serves as a stabilizer for a customer's sales. This can be due to its role as an insurance, in which risk is shifted from the customer onto their supplier (which now carries now the risk of project failure). Also, during good times, liquidity is abundant and firms are able to shift liquidity to a liquidity-starved production partner in order to maintain stable production. 


\section{Appendix A}

\section{Parameter estimation}

Given the vector of sensitivity parameters $w$, the distribution of a single default event in a obligor class $k$ is given by:

$$
p_{i}=P\left[D_{i, t+1}=1\right]=P\left[A_{i, t+1}<\Phi^{-1}\left(\bar{p}_{k}\right)\right]=\int_{-\infty}^{\Phi^{-1}\left(\bar{p}_{k}\right)} f\left(A_{i, t+1}\right) d A_{i, t+1}
$$

where $f(\cdot)$ is a density function and in our application of the model takes the form of normal probability distribution function and $\Phi(\cdot)$ denotes the cumulative standard normal distribution function. By design for any $i$ and $j$ where $i \neq j$ the probability distribution of a default event, in which two obligors fail to meet their payments is modelled as a bivariate normal distribution:

$$
\begin{aligned}
f_{i j}\left(A_{i, t} ; A_{j, t}\right) & =\frac{1}{2 \pi|\Sigma|^{1 / 2}} \exp \left\{-\frac{1}{2} A^{T} \Sigma^{-1} A\right\} \\
\text { where } \quad A & =\left[\begin{array}{c}
A_{i, t} \\
A_{j, t}
\end{array}\right] \\
\text { and } \Sigma & =\left[\begin{array}{cc}
1 & w_{k} w_{l} \Omega_{k l} \\
w_{k} w_{l} \Omega_{k l} & 1
\end{array}\right]
\end{aligned}
$$

The above joint density of $A_{i, t}$ and $A_{i, t}$ can be transformed by standardizing the vector $A$ and integrating out the effects of the risk factors. Consequently one will obtain the probability of an event, in which both obligors default at once:

$$
\begin{aligned}
p_{k l} & \equiv P\left[D_{i, t+1}=1, D_{j, t+1}=1\right] \\
& =\int_{-\infty}^{\Phi^{-1}\left(\bar{p}_{l}\right)} \Phi\left(\frac{\Phi^{-1}\left(\bar{p}_{k}\right)-\Omega_{k l} w_{k} w_{l} y}{\sqrt{1-\Omega_{k l}^{2} w_{k}^{2} w_{l}^{2}}}\right) \frac{1}{\sqrt{2 \pi}} \exp \left(-\frac{1}{2} y^{2}\right) d y
\end{aligned}
$$


The expression in (A.6) gives the population moment for joint probability of default. The sample moment is derived in the following way. We take the joint probability of default for two firms $i$ and $j$ from two different obligor classes $k$ and $l$ to be an average of all occasions, in which both firms are simultaneously in default:

$$
\hat{p}_{i j}=\frac{1}{T} \sum_{t=1}^{T}\left(D_{i, t+1} \cdot D_{j, t+1}\right)
$$

Next, to arrive at sample moment of joint probability of default for two obligor classes, we need to take an average over all possible pairs of firms in both obligor classes:

$$
\hat{p}_{k l}=\frac{1}{N_{k, t} N_{l, t}} \sum_{i \in k}^{N_{k, t}} \sum_{j \in l}^{N_{l, t}} \frac{1}{T} \sum_{t=1}^{T}\left(D_{i, t+1} \cdot D_{j, t+1}\right)
$$

where $N_{k t}$ and $N_{l t}$ is the number of firms in obligor class and respectively. Now we change the order of summation, which gives us that the sample moment for joint probability of default is an average over time of the product of observed default frequencies:

$$
\begin{aligned}
\hat{p}_{k l} & =\frac{1}{T} \sum_{t=1}^{T} \frac{\sum_{i \in k}^{N_{k, t}} D_{i, t+1}}{N_{k, t}} \frac{\sum_{j \in l}^{N_{l, t}} D_{j, t+1}}{N_{l, t}} \\
\Rightarrow \hat{p}_{k l} & =\frac{1}{T} \sum_{t=1}^{T}\left(O D F_{k, t} \cdot O D F_{l, t}\right)
\end{aligned}
$$

The GMM estimator proposed minimizes the distance between the population and sample moments with respect to the parameter vector $\theta$. 


\section{Appendix B}

\section{Industry linkages}

The IO data cover commodity flows for 195 IO industries. We recode the firm NAICS and SIC codes into one of the 195 IO industries using concordance tables between IO and 2007 NAICS provided by the U.S. Bureau of Labor Statistics. Moreover, the concordance tables between 2007 NAICS, 2002 NAICS and SIC are provided by the U.S. Bureau of Economic Analysis. Our analysis focuses on 77 IO manufacturing industries. In a few cases, the procedure maps one SIC into few IO industries. In this case we follow Ahern and Harford (2014) and assign a firm from that SIC industry into one of those IO industries at random. It allows us to preserve the behavior of firms in the aggregate in one IO industry while matching the firms to a single IO industry.

To identify the supplier-customer pairs, we construct matrices with commodity flows from the annual Make and Use tables. Following Ahern and Harford (2014) the commodity output matrix $S H A R E_{I x K}$ is derived from the make table $M_{I x K}$ and records the proportion of an industry $i$ in production of a commodity $k$. On the other hand, the $u_{k i}$ element of a use matrix $U_{K x I}$ gives the dollar amount of commodity $k$ used as an intermediate input in production process of industry $i$. In the next step, the REVSHARE $E_{I x I}$ is an industry-by-industry matrix, which records the dollar flow from the user industries in columns to the producer industries in rows:

$$
R E V S H A R E=S H A R E \times U
$$

Next, the customers' matrix $C U S T_{I x I}$ is derived as a proportion of intermediate products produced and supplied by a row industry to its customers. It specifies how much of the outputs of the production process is supplied to a given customer. Analogously, the suppliers' matrix 
$S U P P_{I x I}$ records the proportion of intermediate products purchased and used by the column industry from its suppliers. In other words it indicates how much of the inputs to the production process comes from a given supplier. A relationship is identified as a customer or supplier relationship if entries of $C U S T$ or $S U P P$ are greater than $1 \%$. 


\section{Appendix $\mathrm{C}$}

\section{Competitive equilibrium}

We derive the competitive equilibrium by following closely Acemoglu et al. (2012). The competitive equilibrium is a set of commodity prices $p_{i}$, wage $h$ and consumption choices $c_{i}$ that satisfy the representative household's utility maximization problem; firms' profit maximization problem subject to condition that the commodity and labor markets clear, that is:

$$
\begin{gathered}
c_{i}+\sum_{j=1}^{n} x_{i j}=x_{i} \\
\sum_{i=1}^{n} l_{i}=1
\end{gathered}
$$

From the firm $i$ profit maximization problem subject to labor and input choices, $l_{i}$ and $x_{i j}$ respectively, we obtain:

$$
\begin{gathered}
l_{i}=\frac{\alpha x_{i} p_{i}}{h} \\
x_{i j}=\frac{x_{i} p_{i}(1-\alpha)(1-\beta+b \beta)}{p_{j}}
\end{gathered}
$$

In the next step we substitute the optimal labor and input choices into the production function. By taking logs and simplifying we arrive at the following expression:

$$
\begin{aligned}
\alpha \ln (h)= & \alpha \varepsilon_{i}+C+\ln \left(p_{i}\right)+(1-\alpha)(1-\beta+b \beta) \sum_{j=1}^{n} w_{i j} \ln \left(w_{i j}\right) \\
& -(1-\alpha)(1-\beta+b \beta) \sum_{j=1}^{n} w_{i j} \ln \left(p_{j}\right)
\end{aligned}
$$


where $C$ is a constant independent of prices, wage and consumption defined as:

$$
C=\alpha \ln (\alpha)+(1-\alpha) \ln (1-\alpha)+(1-\alpha) \ln (1-\beta+b \beta)
$$

Next we multiply by the $i$ th element of the $u$ vector and we sum over all $i$.

$$
\begin{aligned}
\sum_{i=1}^{n} u_{i} \ln (h)= & \sum_{i=1}^{n} u_{i} \varepsilon_{i}+\frac{C}{\alpha} \sum_{i=1}^{n} u_{i}+\frac{1}{\alpha} \sum_{i=1}^{n} \ln \left(p_{i}\right) u_{i} \\
& +\frac{(1-\alpha)}{\alpha}(1-\beta+b \beta) \sum_{i=1}^{n} \sum_{j=1}^{n} u_{i} w_{i j} \ln \left(w_{i j}\right) \\
& -\frac{(1-\alpha)}{\alpha}(1-\beta+b \beta) \sum_{i=1}^{n} \sum_{j=1}^{n} w_{i j} \ln \left(p_{j}\right) u_{i}
\end{aligned}
$$

Denote the vector of logarithm prices by $\ln (p)$ then then the expression:

$$
\frac{1}{\alpha} \sum_{i=1}^{n} \ln \left(p_{i}\right) u_{i}-\frac{(1-\alpha)}{\alpha}(1-\beta+b \beta) \sum_{i=1}^{n} \sum_{j=1}^{n} w_{i j} \ln \left(p_{j}\right) u_{i}
$$

in vector notation is equal to:

$$
\frac{1}{\alpha} \ln (p) u-\frac{(1-\alpha)}{\alpha}(1-\beta+b \beta) \ln (p) W^{\prime} u=\frac{1}{\alpha} \ln (p)\left[I-\frac{(1-\alpha)}{\alpha}(1-\beta+b \beta) W^{\prime}\right] u
$$

With $u=\frac{\alpha}{n}\left[I-(1-\alpha)(1-\beta+b \beta) W^{\prime}\right]^{-1} \mathbf{1}$ the expression in (C.9) simplifies to:

$$
\frac{1}{\alpha} \ln (p) u-\frac{(1-\alpha)}{\alpha}(1-\beta+b \beta) \ln (p) W^{\prime} u=\frac{1}{n} \ln (p) \mathbf{1}
$$

From constant returns to scale we have that $\sum_{i=1}^{n} u_{i}=1$. We use this property to obtain that:

$$
\begin{aligned}
& y=\mu+u^{\prime} \varepsilon \\
& \text { where } u=\frac{\alpha}{n}\left[I-(1-\alpha)(1-\beta+b \beta) W^{\prime}\right]^{-1} \mathbf{1} \\
& \text { and } \quad \mu=\frac{1}{n} \sum_{i=1}^{n} p_{i}+\frac{C}{\alpha}+\frac{1-\alpha}{\alpha}(1-\beta+b \beta) \sum_{i=1}^{n} \sum_{j=1}^{n} u_{i} w_{i j} \ln \left(w_{i j}\right)
\end{aligned}
$$

The aggregate fluctuations are equal to a sum of all idiosyncratic shocks weighted by the importance of firms in their production and trade credit networks. 


\section{Appendix D}

\section{Taylor expansion}

We approximate vector $u$ by taking the first order Taylor approximation of $u$ around $\eta=0$ :

$$
u \approx u(0)+\frac{u^{\prime}(0)}{1 !}(\eta-0)=\frac{\alpha}{n}\left[I-(1-\alpha) W^{\prime}\right]^{-1} \mathbf{1}+\eta u^{\prime}(o)
$$

To differentiate vector $u$ we use the property that a derivative of a matrix inverse is equal to:

$$
\frac{d M^{-1}}{d \eta}=-M^{-1} \frac{d M}{d \eta} M^{-1}
$$

With the matrix $M=\left[I-(1-\alpha)(1+\eta \beta) W^{\prime}\right]$ we get:

$$
\begin{aligned}
\frac{d M^{-1}}{d \eta} & =-\left[I-(1-\alpha)(1+\eta \beta) W^{\prime}\right]^{-1} \\
& \times \frac{d\left[I-(1-\alpha)(1+\eta \beta) W^{\prime}\right]}{d \eta}\left[I-(1-\alpha)(1+\eta \beta) W^{\prime}\right]^{-1}
\end{aligned}
$$

where the derivative of matrix $\mathrm{M}$ with respect to $\eta$ is given by: $\frac{d M}{d \eta}=$ $-(1-\alpha) \beta W^{\prime}$. This yields that:

$$
\begin{aligned}
u & \approx \frac{\alpha}{n}\left[I-(1-\alpha) W^{\prime}\right]^{-1} \mathbf{1}+\eta \frac{\alpha}{n}\left[I-(1-\alpha) W^{\prime}\right]^{-1}(1-\alpha) \beta W^{\prime}\left[I-(1-\alpha) W^{\prime}\right]^{-1} \mathbf{1} \\
& =v+\eta\left[I-(1-\alpha) W^{\prime}\right]^{-1}(1-\alpha) \beta W^{\prime} v .
\end{aligned}
$$


Appendix D. TAYlor EXPANSION 


\section{Appendix E}

\section{Firm level relationship}

We begin from the aggregate output relationship as in equation (4.2) in the index notation:

$$
y=\mu+\sum_{j}^{n} u_{j} \varepsilon_{j}
$$

where $u_{j}$ is the $j$ th element of vector $u$ defined as in equation (4.5):

$$
u \approx v+\eta\left[I-(1-\alpha) W^{\prime}\right]^{-1}(1-\alpha) \beta W^{\prime} v,
$$

and the influence vector of Acemoglu et al. (2012) is defined as in equation (4.4):

$$
v=\frac{\alpha}{n}\left[I-(1-\alpha) W^{\prime}\right]^{-1} \mathbf{1} .
$$

Let us define matrix $D \equiv \frac{\alpha}{n}\left[I-(1-\alpha) W^{\prime}\right]^{-1}$ such that the influence vector of Acemoglu et al. (2012) writes as $v=D \mathbf{1}$, then from (E.1), (E.2) and (E.3) we have:

$$
y=\mu+\sum_{j=1}^{n}[D \mathbf{1}]_{j} \varepsilon_{j}+\eta \sum_{j=1}^{n}\left[\left(1-(1-\alpha) W^{\prime}\right)^{-1}(1-\alpha) \beta W^{\prime} D \mathbf{1}\right]_{j} \varepsilon_{j},
$$

or summing also in the $i$ dimension:

$y=\mu+\sum_{i=1}^{n} \sum_{j=1}^{n} D_{j i} \varepsilon_{j}+\eta \sum_{i=1}^{n} \sum_{j=1}^{n}\left[\left(1-(1-\alpha) W^{\prime}\right)^{-1}(1-\alpha) \beta W^{\prime} D\right]_{j i} \varepsilon_{j}$. 
For $y=\sum_{i=1}^{n} y_{i}$ the expression in (E.5) becomes:

$\sum_{i=1}^{n} y_{i}=\mu+\sum_{i=1}^{n} \sum_{j=1}^{n} D_{j i} \varepsilon_{j}+\eta \sum_{i=1}^{n} \sum_{j=1}^{n}\left[\left(1-(1-\alpha) W^{\prime}\right)^{-1}(1-\alpha) \beta W^{\prime} D\right]_{j i} \varepsilon_{j}$.

(E.6)

which at the firm level is equivalent to:

$$
y_{i}=\mu_{i}+\sum_{j=1}^{n} D_{j i} \varepsilon_{j}+\eta \sum_{j=1}^{n}\left[\left(1-(1-\alpha) W^{\prime}\right)^{-1}(1-\alpha) \beta W^{\prime} D\right]_{j i} \varepsilon_{j} .
$$




\section{Bibliography}

Abadie, Alberto, and Guido W. Imbens, 2007, Bias corrected matching estimators for average treatment effects, mimeo Harvard University.

Abramovitz, Moses, 1948, The role of inventories in business cycles, National Bureau of Economic Research Occasional Paper 26.

Acemoglu, Daron, Vasco M. Carvalho, Asuman Ozdaglar, and Alireza Tahbaz-Salehi, 2012, The network origins of aggregate fluctuations, Econometrica 80, 1977-2016.

Acharya, Viral V., Sreedhar T. Bharath, and Anand Srinivasan, 2007, Does industry-wide distress affect defaulted firms? Evidence from creditor recoveries, Journal of Financial Economics 85, $787-821$.

Ahern, Kenneth R., and Jarrad Harford, 2014, The importance of industry links in merger waves, The Journal of Finance 69, 527-576.

Ali, Ashiq, Sandy Klasa, and Eric Yeung, 2009, The limitations of industry concentration measures constructed with compustat data: Implications for finance research, The Review of Financial Studies 22, 3839-3871.

Allayannis, George, and Jane Ihrig, 2001, Exposure and markups, The Review of Financial Studies $14,805-835$.

Azizpour, Shahriar, Kay Giesecke, and Gustavo Schwenkler, 2012, Exploring the sources of default clustering, Working Paper.

Bams, Dennis, Magdalena Pisa, and Christian Wolff, 2012, Modeling default correlation in a U.S. retail portfolio, CEPR Working Paper No. 9205.

Basel Committee on Banking Supervision, 2005, An explanatory note on the Basel II IRB risk weight functions, Bank for International Settlements.

— 2006, International convergence of capital measurement and capital standards, Bank for International Settlements.

, 2009, Guidelines for computing capital for incremental default risk in the trading book, Bank for International Settlements, p.1, §1.

, 2011, Basel III: A global regulatory framework for more resilient banks and banking systems, Bank for International Settlements, p.39, §102.

Benmelech, Efraim, and Nittai K. Bergman, 2011, Bankruptcy and the collateral channel, The Journal of Finance 66, 2061-2084.

Bernanke, Ben, and Mark Gertler, 1989, Agency costs, net worth, and business fluctuations, The American Economic Review 79, 14-31. 
, and Simon Gilchrist, 1996, The Financial Accelerator and the Flight to Quality, The Review of Economics and Statistics 78, 1-15.

Berndt, Antje, Peter Ritchken, and Zhiqiang Sun, 2010, On correlation and default clustering in credit markets, The Review of Financial Studies 23, 2680-2729.

Bertrand, Marianne, and Sendhil Mullainathan, 2003, Enjoying the quiet life? corporate governance and managerial preferences, Journal of Political Economy 111, 1043-1075.

Bharath, Sreedhar T., and Tyler Shumway, 2008, Forecasting default with the Merton Distance to Default model, The Review of Financial Studies 21, 1339-1369.

Black, Fischer, and John C. Cox, 1976, Valuing corporate securities: Some effects of bond indenture provisions, The Journal of Finance 31, 351-367.

Botha, Marius, and Gary van Vuuren, 2010, Implied asset correlation in retail loan portfolios, Journal of Risk Management in Financial Institutions 3, 156-173.

Bryant, Chris, 2013, Industrial smes face battle to get bank loans, Financial Times, May 27.

Burkart, Mike, and Tore Ellingsen, 2004, In-kind finance: A theory of trade credit, American Economic Review 94, 569-590.

Caballero, Ricardo J., and Alp Simsek, 2013, Fire sales in a model of complexity, The Journal of Finance 68, 2549-2587.

Carling, Kenneth, Lars Rönnegård, and Kasper Roszbach, 2004, Is firm interdependence within industries important for portfolio credit risk?, Sveriges Riksbank Working Paper Series 168.

Carvalho, Vasco, and Xavier Gabaix, 2013, The great diversification and its undoing, American Economic Review 103, 1697-1727.

Cavalcanti, Marco Antonio F.H., 2010, Credit market imperfections and the power of the financial accelerator: A theoretical and empirical investigation, Journal of Macroeconomics 32, 118 144 .

Cheng, Louis T.W., and James E. McDonald, 1996, Industry structure and ripple effects of bankruptcy announcements, Financial Review 31, 783-807.

Cohen, Lauren, and Andrea Frazzini, 2008, Economic links and predictable returns, The Journal of Finance 63, 1977-2011.

Conley, Timothy G., and Bill Dupor, 2003, A Spatial Analysis of Sectoral Complementarity, Journal of Political Economy 111, 311-352.

Crosbie, Peter, and Jeff Bohn, 2003, Modeling default risk, Moody's KMV Working Paper.

Cuñat, Vicente, 2007, Trade credit: Suppliers as debt collectors and insurance providers, Review of Financial Studies 20, 491-527.

di Giovanni, Julian, Andrei A. Levchenko, and Isabelle Méjean, 2014, Firms, destinations, and aggregate fluctuations, Econometrica 82, 1303-1340.

Dietsch, Michel, and Joël Petey, 2002, The credit risk in SME loans portfolios: Modeling issues, pricing, and capital requirements, Journal of Banking ES Finance 26, 303-322.

2004, Should SME exposures be treated as retail or corporate exposures? A comparative analysis of default probabilities and asset correlations in French and German SMEs, Journal of Banking $\&$ Finance 28, 773-788. 


\section{Paper.}

Duffie, Darrell, Andreas Eckner, Guillaume Horel, and Leandro Saita, 2009, Frailty correlated default, The Journal of Finance 64, 2089-2123.

Duffie, Darrell, Leandro Saita, and Ke Wang, 2007, Multi-period corporate default prediction with stochastic covariates, Journal of Financial Economics 83, 635-665.

Düllmann, Klaus, and Harald Scheule, 2003, Determinants of the asset correlations of german corporations and implications for regulatory capital, Deutsches Bundesbank Working Paper.

Gabaix, Xavier, 2011, The granular origins of aggregate fluctuations, Econometrica 79, 733-772.

Gao, Janet, 2014, Business networks, firm connectivity, and firm policies, Working Paper.

Giesecke, Kay, 2006, Default and information, Journal of Economic Dynamics and Control 30, 2281-2303.

Glennon, Dennis, and Peter Nigro, 2005, Measuring the default risk of small business loans: A survival analysis approach, Journal of Money, Credit and Banking 37, 923-947.

Gordy, Michael B., 2000, A comparative anatomy of credit risk models, Journal of Banking $\&$ Finance 24, 119-149.

— , 2003, A risk-factor model foundation for ratings-based bank capital rules, Journal of Financial Intermediation 12, 199-232.

Gupton, Greg M., Christopher C. Finger, and Mickey Bhatia, 1997, CreditMetrics - technical document, J. P. Morgan.

Hertzel, Michael G., Zhi Li, Micah S. Officer, and Kimberly J. Rodgers, 2008, Inter-firm linkages and the wealth effects of financial distress along the supply chain, Journal of Financial Economics 87, 374-387.

Hertzel, Michael G., and Micah S. Officer, 2012, Industry contagion in loan spreads, Journal of Financial Economics 103, 493-506.

Holly, Sean, and Ivan Petrella, 2012, Factor demand linkages, technology shocks, and the business cycle, The Review of Economics and Statistics 94, 948-963.

Horvath, Michael, 2000, Sectoral shocks and aggregate fluctuations, Journal of Monetary Economics 45, 69-106.

Jarrow, Robert A., and Fan Yu, 2001, Counterparty risk and the pricing of defaultable securities, The Journal of Finance 56, 1765-1799.

Jennrich, Robert I., 1970, An asymptotic chi $^{2}$ test for the equality of two correlation matrices, Journal of the American Statistical Association 65, 904-912.

Jorion, Philippe, and Gaiyan Zhang, 2009, Credit contagion from counterparty risk, The Journal of Finance 64, 2053-2087.

Kiyotaki, Nobuhiro, and John Moore, 1997, Credit cycles, Journal of Political Economy 105, $211-248$.

— 2002, Balance-sheet contagion, The American Economic Review 92, 46-50.

Klein, Karen E., 2009, Survival advice for auto parts suppliers, Businessweek, June 16. 
Kraft, Holger, and Mogens Steffensen, 2007, Bankruptcy, counterparty risk, and contagion, Review of Finance 11, 209-252.

Lang, Larry H. P., and René M. Stulz, 1992, Contagion and competitive intra-industry effects of bankruptcy announcements. An empirical analysis, Journal of Financial Economics 32, 45-60.

Lee, Joseph, Joy Wang, and Jing Zhang, 2009, The relationship between average asset correlation and default probability, Moody's KMV Working Paper.

Long, John B. Jr., and Charles I. Plosser, 1983, Real business cycles, Journal of Political Economy $91,39-69$.

Lopez, Jose A., 2004, The empirical relationship between average asset correlation, firm probability of default, and asset size, Journal of Financial Intermediation 13, 265-283.

Lucas, Robert E., 1977, Understanding business cycles, Carnegie-Rochester Conference Series on Public Policy 5, 7-29.

Malmendier, Ulrike, and Geoffrey Tate, 2009, Superstar ceos, The Quarterly Journal of Economics $124,1593-1638$.

Manski, Charles F, 1993, Identification of Endogenous Social Effects: The Reflection Problem, Review of Economic Studies 60, 531-42.

McNeil, Alexander J., and Jonathan P. Wendin, 2007, Bayesian inference for generalized linear mixed models of portfolio credit risk, Journal of Empirical Finance 14, 131-149.

Merton, Robert C., 1974, On the pricing of corporate debt: The risk structure of interest rates, The Journal of Finance 29, 449-470.

Moscarini, Giuseppe, and Fabien Postel-Vinay, 2012, The Contribution of Large and Small Employers to Job Creation in Times of High and Low Unemployment, American Economic Review 102, 2509-39.

Phelan, William, 2011, Fuelling economic growth. Where's the impediment to returning to the good old days of small-business expansion and more start-ups?, The RMA Journal pp. 25-31.

Raddatz, Claudio, 2010, Credit chains and sectoral comovement: Does the use of trade credit amplify sectoral shocks?, The Review of Economics and Statistics 92, 985-1003.

Schönbucher, Philipp J., 2000, Factor models for portofolio credit risk, Bonn Econ Discussion Papers 16/2001.

Shea, John S, 2002, Complementarities and Comovements, Journal of Money, Credit and Banking $34,412-33$.

Steijvers, Tensie, and Mervi Niskanen, 2009, Cash holdings of small and medium sized private family firms: Evidence on the effect of generational evolution, Working Paper.

The Economist, 2010, Small-business finance: Markets for minnows, April 15.

Vasicek, Oldrich, 1987, Probability of loss on loan portfolio, KMV Working Paper.

Vlasic, Bill, and Leslie Wayne, 2008, Auto suppliers share in the anxiety, The New York Times, December 12.

Wagner, Stephan M., Christoph Bode, and Philipp Koziol, 2011, Negative default dependence in supplier networks, International Journal of Production Economics 134, 398-406. 


\section{Knowledge valorization}

Credit came to existence together with the first human civilizations. The first known record regulating price of credit (interest) comes from the ancient Babylon. It sets the maximum rate of interest at $33.34 \%$ per annum in case of loans of grains and at $20.00 \%$ in case of loans of silver. Nowadays credit is usually available at a significantly lower price and can take many forms starting from credit cards, through trade credit commitments to commercial papers.

Credit allows for consumption smoothing and spending today the future cash flows. For example, if it were not for credit, young households with no equity would not be able to afford own house. But regardless of its forms or price, credit comes with an embedded risk of not being paid in full. If a lender holds a single loan, the borrower's default with zero recovery rate can translate into a $100 \%$ loss. That is why there is an incentive to hold multiple loans which offer some diversification. Moreover those loans should be uncorrelated such that the default events do not occur at the same time.

This thesis deals with issues related to such correlated defaults and more broadly to co-movements between firms. It has various social and economic contributions to financial regulation, risk management practices at financial institutions and policy making.

\section{Capital adequacy}

Chapter two critically evaluates assumptions of the Basel capital adequacy framework in small business lending and proposes alternatives. We find that small businesses are subject to inefficient capital allocation imposed by the regulator. The Basel II formula significantly overstates the asset correlation and thus capital requirement for small businesses. The unexpected losses in portfolios of loans to small business are significantly overstated relative to their riskiness. This is not observed 
in other asset classes as i.e. large corporate loans. It creates perverse incentives for financial institutions that flee to other obligor classes in which loans are less costly to hold. Additionally, it encourages more financing in the corporate sector rather than in small business economy, an outcome undesired by the policy makers.

\section{Financial modeling}

Chapter two proposes an econometric model to estimate and test asset correlations of the regulatory Basel II and Basel III credit risk models in the context of small business lending. In particular, we construct and program a flexible General Method of Moments estimator of default and asset correlation between various firms or industries. Ideally, this flexible estimator could be adopted by banks to estimate their asset correlations to maintain adequate capital buffers against unexpected losses in their loan portfolios.

We also draw the attention to the problem of parameter uncertainly in financial modeling. This issue is often neglected at bank's risk management divisions and in policy making. Only recently the current trend of stress testing might partially address the problem, however, it comes at a great computational cost. That is why this thesis recommends that banks take into account limitations of the models used in risk management divisions and consider that the normal distribution used in much of the modeling might not be appropriate to the environment the bank is operating in. Instead they may adopt some fat tail distributions.

\section{Predicting default clustering}

Measuring and predicting correlated defaults in portfolios of loans to small businesses is at the heart of Chapter three. Recent research shows that parts of co-movement between firms can be explained by counterparty risk. But it is prohibitively expensive to obtain individual counterparty exposures for small businesses. So we propose to replace this information with public information on industry level which identifies industries linked by production process. What does this mean for banks? This type of information can be used in bank's risk management division to detect how much of their portfolio is potentially exposed to a spillover form a financial distress somewhere in the economy. 
Also, we offer an efficient way for banks to track and prepare for default clustering on small business loan portfolios. We identify easy, publicly available warning signals that banks should be concerned with as they are followed by increased default rates on their small business loan portfolios. We identify those signals to be defaults on S\&P rated debt. Our recommendation is that, following a default on S\&P rated debt, banks holding loans to small businesses operating in industries supplying to the distressed industry should raise their capital buffers in preparation for increase in losses. This finding is important to financial institutions which are now equipped with tools to predict increased default rates and to regulators which may request higher required capital following the warning signals. This then improves the financial soundness of the financial institutions and stability of the financial system.

Lastly, this study provides an original perspective on aspects of portfolio concentration and default risk transmission. In particular, we assume the perspective of small business finance providers (banks) which might be concerned with the ripple effect on their concentrated loan portfolios. We examine how magnitude of ripple effects changes with portfolio concentration into large, interconnected and highly concentrated industries. We find that portfolio constructed of loans to small businesses operating in industries with high markup has reduced default rates following a distress (default on S\&P rated debt) in a linked industry.

\section{Supervision of strategic firms}

Lastly, in Chapter four we find that firms which take an important position in the economy as suppliers of inputs or suppliers of trade credit to their customers can be responsible for some of the fluctuations in the economy. This might be of interest to policy makers and supervisors. Any distress such firm is facing will be reflected in its direct customers and can be propagated even to more distant customers creating secondary effects. Policy makers and supervisors could potentially step in in such situations to ease the distress or to create a buffer to prevent the distress from spilling onto the rest of the economy. 


\section{Nederlandse samenvatting}

Kleine ondernemingen vormen een cruciaal onderdeel van elke ontwikkelde economie. Ze hebben ongeveer $50 \%$ van de beroepsbevolking in dienst en zijn de drijfveer in innovatie. Beleidsmakers en regelgevers ondersteunen daarom het financieren van activiteiten van kleine ondernemers zodat kleine ondernemingen kunnen groeien en hun potentieel kunnen waarmaken. Door middel van een reeks onderzoeken over het kredietrisico van kleine ondernemingen analyseren we de comovements met betrekking tot kredietrisico tussen bedrijven onderling, tussen bedrijven en bedrijfssectoren en tussen bedrijven productiepartners. Vanuit drie instellingsperspectieven in het bijzonder: het asymptotisch enkelvoudige factormodel uit hoofdstuk twee, de empirische difference-in-difference-benadering uit hoofdstuk drie en een multisectoraal economisch model uit hoofdstuk vier, bespreken we het al dan niet bestaan van, en de bronnen van co-movements tussen de activiteiten van bedrijven en hun kredietrisico.

In deze dissertatie stellen we de volgende vragen: Adresseert de regelgeving van Basel op correcte wijze de kwestie van gecorreleerde oninbaarheid van leenportfolio's aan het kleinbedrijf? Zijn productiekoppelingen op sectorniveau geschikt voor dit model en houden ze rekening met gecorreleerde oninbaarheid van leenportfolio's aan het kleinbedrijf zonder tegenpartijrisico zoals portfolio's van leningen aan kleine ondernemingen? Wat is de rol van handelskrediet in het doorgeven van idiosyncratische schokken tussen productiepartners? De eerste twee onderzoeken behandelen voornamelijk de kwesties rond gecorreleerde oninbaarheid tussen kleine ondernemingen, waarbij het laatste onderzoek de co-movements beschouwt tussen productiepartners die van handelskrediet gebruikmaken.

In dit proefschrift zijn onze bevindingen dat de Basel II het benodigde kapitaal voor portfolio's voor leningen aan kleine ondernemingen overschat. Leningen voor kleine ondernemingen vormen een veel 
veiligere investering dan de regelgever zou suggereren. We geven tevens aan dat kredietrisico voor een kleine onderneming overwegend is gerelateerd aan karakteristieken van het bedrijf zelf en niet zozeer aan de economie of omstandigheden geldend voor de bedrijfssector. Slechts 0.00-3.39\% van de variabiliteit van activa wordt verklaard door risicofactoren geldend voor de economie. De resterende $96.61 \%-100.00 \%$ van het risico voor het kleinbedrijf komt door veranderingen in bedrijfsspecifieke karakteristieken. Daarnaast lijden de meer kredietwaardige kleine ondernemingen, naar mate van hun risicogehalte, aan de meest stringente kapitaalvereisten.

In hoofdstuk drie vinden we bewijs dat financiële nood in een klantenindustrie gekoppeld is aan een hoger kredietrisico onder toeleveraars aan kleine ondernemingen. We laten zien dat wanbetalingpercentages in kleine ondernemingen significant hoger zijn na financiële nood in een sector die hun producten koopt of na financiële nood in dezelfde sector. We vinden bewijzen voor negatieve welvaartseffecten die naar kleine ondernemingen doorvloeien. Tevens observeren we dat een groot aantal bedrijven in een bedrijfssector als stootkussen dient voor het overbrengen van wanbetalingsrisico, net zoals de brede economische banden wat diversificatievoordelen geven.

Hoofdstuk vier systematiseert de bevindingen uit hoofdstuk drie in een model van een multisectorale economie en levert bewijs dat productiekoppelingen samen met kredietketens (vertegenwoordigd door handelskrediet) belangrijk zijn voor de transmissie van idiosyncratische schokken (op bedrijfsniveau) naar andere bedrijven in de economie. We bouwen voort op de gedachte dat kredietketens ontstaan via productiekoppelingen en dat ze de idiosyncratische schok versterken omdat bedrijven niet alleen aan tekort aan input maar ook aan liquiditeitsproblemen blootgesteld kunnen staan.

Met gebruik van disgeaggregeerde gegevens op bedrijfsniveau laten we zien dat over het algemeen handelskrediet vergezeld van productiekoppelingen een belangrijk kanaal is waarlangs financiële nood van het ene naar het andere bedrijf doorvloeit. Dit kan een schok richting leverancier verergeren en deze kan zo verder stroomafwaarts naar zijn klant doorvloeien. Handelskredietkoppelingen propageren met name tijdens een recessie schokken naar downstream-leveranciers die doorvloeien naar hun upstream-klant. In deze slechte tijden hebben bedrijven liquiditeitsproblemen en kunnen ze zich een verminderde handelskredietverstrekking niet veroorloven. In goede tijden verleent handelskrediet een rol van stabilisator die de volatiliteit van de verkopen van het bedrijf 
vermindert. In dat soort tijden hebben bedrijven voldoende liquiditeit om die naar de minder liquide productiepartner door te schuiven en zo een constante productie te garanderen. 


\section{Curriculum Vitae}

Magdalena Pisa was born on 5 March 1985 in Olsztyn, Poland. She received her Licentiate in Economics from Warsaw University of Life Sciences. She also holds Master of Science in Food and Resource Economics from University of Bonn where she graduated top of her class with the Jahrgangsbeste title and Master in Financial Economics from University of Luxembourg.

In June 2011 Magdalena started her PhD studies jointly at Maastricht University and University of Luxembourg, where she also taught an MBA class on Excel Applied to Finance and a bachelor course in Probability and Statistics. In 2014 I visited the Johnson Graduate School of Management, Cornell University.

Her research ideas were awarded a grant from Fonds National de la Recherche Luxembourg for completing her PhD thesis and a 2010 EIB-University Research Sponsorship.

The research collected in this thesis was presented at various international conferences and seminars including AFA in Boston, 8th Financial Risks International Forum in Paris, the Brown-bag seminar at Cornell University, the 2014 Risk Management Conference at National University of Singapore, the 2014 FMA European Conference in Maastricht, 17th SGF Conference in Zürich, 7th Financial Risks International Forum in Paris, seminar at Statistics Norway in Oslo, and the 2013 CREDIT Conference in Venice, the 2013 Risk Management Conference at National University of Singapore, the 2013 FMA European Conference in Luxembourg, the 2013 International Mathematical Finance Conference in Miami, the 2013 EEA-ESEM Conference in Gothenburg, the 2012 Mathematical Finance Days at HEC Montreal, the 2012 Auckland Finance Meeting at Auckland University of Technology, and the 2012 Australasian Finance and Banking Conference at the University of New South Wales. 